Claremont Colleges

Scholarship@ Claremont

CGU Theses \& Dissertations

CGU Student Scholarship

2011

\title{
Do Facework Behaviors Matter During Conflicts Among Online Discussion Team Members?
}

Jesus Herman Canelon

Claremont Graduate University

\section{Recommended Citation}

Canelon, Jesus Herman, "Do Facework Behaviors Matter During Conflicts Among Online Discussion Team Members?" (2011). CGU Theses \& Dissertations. Paper 15.

http://scholarship.claremont.edu/cgu_etd/15

DOI: $10.5642 / \operatorname{cguetd} / 15$

This Open Access Dissertation is brought to you for free and open access by the CGU Student Scholarship at Scholarship @ Claremont. It has been accepted for inclusion in CGU Theses \& Dissertations by an authorized administrator of Scholarship @ Claremont. For more information, please contact scholarship@cuc.claremont.edu. 
Do Facework Behaviors Matter During Conflicts Among Online Discussion Team Members?

By

Jesús H. Canelón H.

Claremont, California 2011

Copyright by Jesús H. Canelón H. 2011

All Rights Reserved 


\section{APPROVAL OF THE REVIEW COMMITTEE}

This dissertation has been duly read, reviewed, and critiqued by the Committee listed below, which hereby approves the manuscripts of Jesús H. Canelón H. as fulfilling the scope and quality requirements for meriting the degree of Doctor of Philosophy in Information Systems and Technology.

Terry Ryan, Ph.D. Claremont Graduate University

Chair

Lorne Olfman, Ph.D. Claremont Graduate University

Member

Benjamin Schooley, Ph.D.

Claremont Graduate University

Member 


\section{Abstract of the Dissertation \\ Do Facework Behaviors Matter During Conflicts Among Online Discussion Team Members?}

\section{by}

\section{Jesús H. Canelón H.}

\section{Claremont Graduate University: 2011}

According to researchers, face is an important possession carried by individuals into interactions with others. Face has been studied in diverse areas such as: politeness, compliance gaining, emotional discourse, negotiations, face-negotiation theory, and conflict. Perhaps because of its value, face can be vulnerable during conflict situations. Facework behaviors are the communicative strategies that people use during conflicts to protect face (theirs or others), threaten others' face, and to avoid or resolve conflicts. So far, studies about facework behaviors have focused on face-to-face interactions. Preliminary studies have shown: a. facework behaviors may affect the outcomes of online discussion teams, b. sex may play a role in the relationship between facework behaviors and online discussion outcomes, and c. conflicts among online discussion team members may influence discussion outcomes.

This research explores more completely the role that facework behaviors play during conflicts, their influence on online discussion outcomes, and the role that sex plays in these matters. Data gathered from surveys and transcripts of participants' online discussion postings show that facework behaviors: a. influence conflict levels, b. influence the outcomes of the online discussion teams, and c. play a moderating role on the relationship between conflicts and online discussion outcomes. They also indicate that sex plays a moderating role in these relationships. Moreover, this study shows that the typology of facework behaviors, originally developed to describe face-related aspects of face-to-face interactions, has value in understanding online discussions. 


\section{Dedication}

To God.

To my mom for all her support, help, words and patience.

To my wife for her support, for always being there along this wonderful journey.

To my dear friend, Eulogio Perez, without his help this could have not been possible.

To all my family for your words and for feeling this achievement as yours.

Thanks to all of you for believing in me.

To the memory of my grandfather Rafael Gustavo and my uncle Gustavo José. 


\section{Acknowledgements}

I would like to thank my committee for their guidance and help to pursue this goal.

To Dr. Terry Ryan, for your immense patience, guidance, and support since my first day at CGU.

To Dr. Lorne Olfman, for your guidance and help editing my writing for the dissertation.

To. Dr Benjamin Schooley, for your suggestions about the dissertation.

To Rob'n Lewis (Director of Accounting), without her this could have not been possible.

To my friends at CGU.

To all the CGU family during this five and a half years.

Thanks. 


\section{Table of Contents}

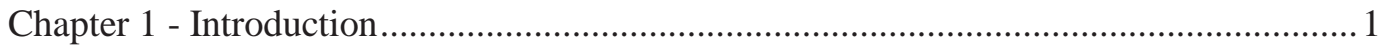

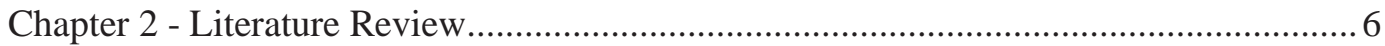

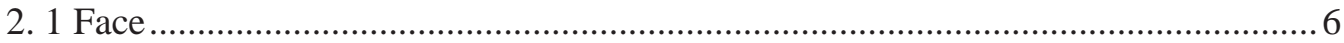

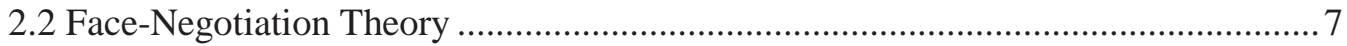

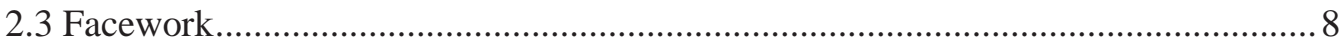

2.3.1 Integrating, Avoiding, and Dominating Facework Categories ........................ 12

2.3.2 Studies about Facework .......................................................................... 12

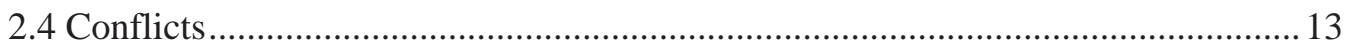

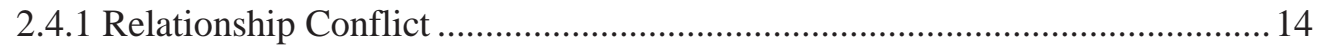

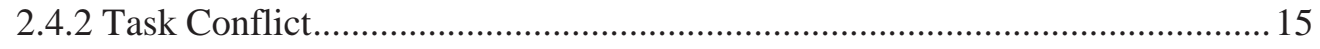

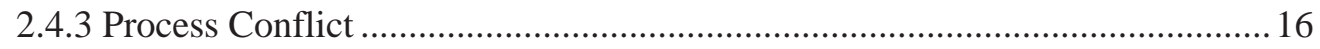

2.5 Other factors impacting online discussion outcomes........................................... 16

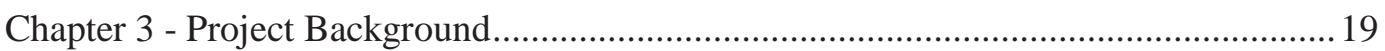

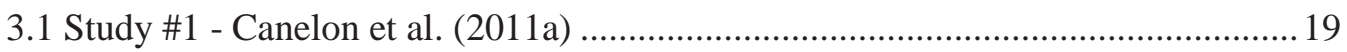

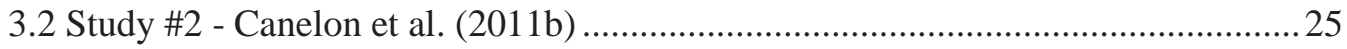

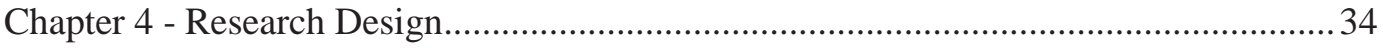

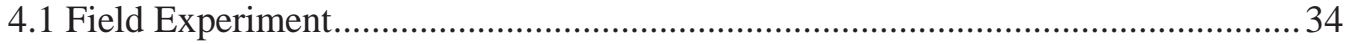

4.2 Independent and Dependent Variables ……............................................................34

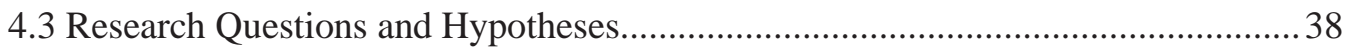

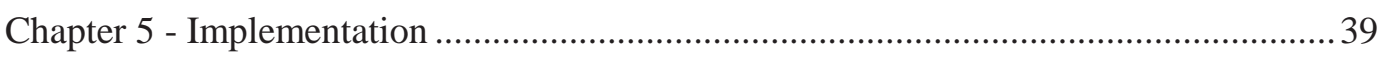

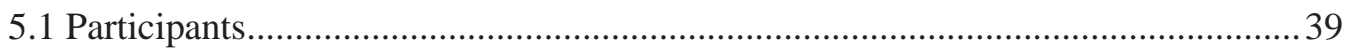

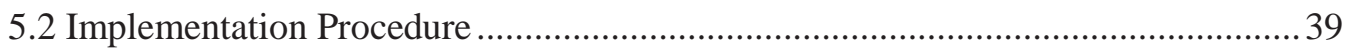

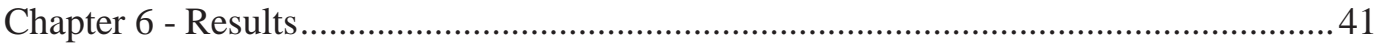

6.1 Quantitative Analysis Results .............................................................................. 41

6.1.1 Hypothesis H1 .............................................................................................. 41

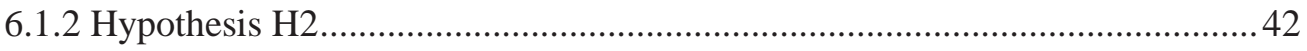

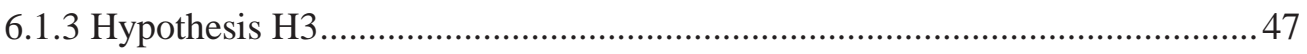

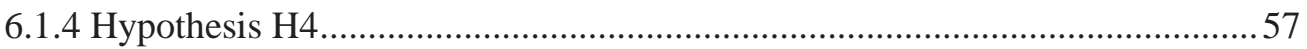

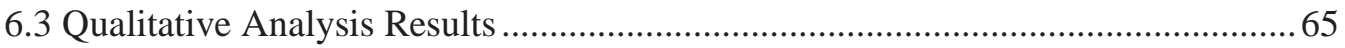

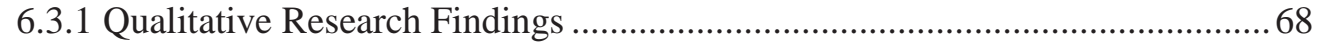

Chapter 7 - Discussion and Implications ………........................................................... 74

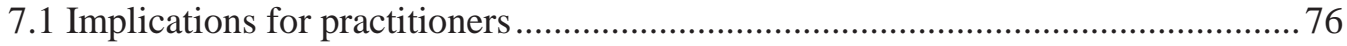

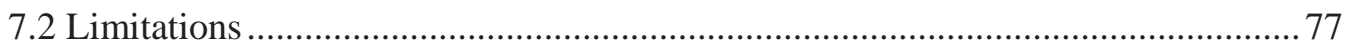




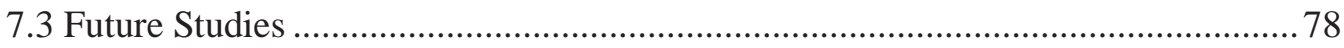

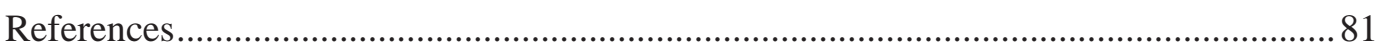

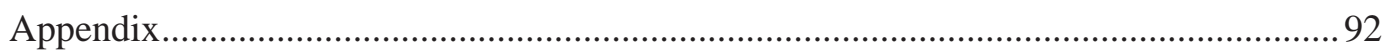

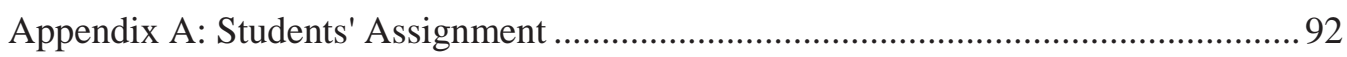

Appendix B: Survey - Conflict -Facework Behaviors - Outcomes............................... 94

Appendix C: Conflicts, Face Facework Behaviors Tutorial ....................................... 106 


\section{List of Tables}

Table 1 - Regression Analysis for the Online Discussion Team Outcomes: Outcome Satisfaction

Table 2 - $\quad$ Regression Analysis for the Online Discussion Team Outcome: Process Satisfaction

Table 3 - $\quad$ Regression Analysis for the Online Discussion Team Outcome: Face Loss

Table 4 - Regression Analysis for the Online Discussion Team Outcome: Team Cohesion

Table 5 - Satisfaction between participants with higher and lower task conflict

Table 6 - Process Satisfaction between participants with higher and lower task conflict

Table 7 - $\quad$ Face Loss between participants with higher and lower task conflict

Table 8 - $\quad$ Team Cohesion between participants with higher and lower task conflict

Table 9 - Satisfaction between participants with higher and lower relationship conflict

Table 10 - Process Satisfaction between participants with higher and lower relationship conflict

Table 11 - Face Loss between participants with higher and lower relationship conflict

Table 12 - Team Cohesion between participants with higher and lower relationship conflict

Table 13 - Satisfaction between participants with higher and lower process conflict

Table 14 - Process Satisfaction between participants with higher and lower process conflict

Table 15 - Face Loss between participants with higher and lower process conflict

Table 16 - Team Cohesion between participants with higher and lower process conflict

Table 17 - Facework Behaviors' Reliability Scores

Table 18 - Conflict Types' Reliabilities Indexes

Table 19 - Regression Analysis. Dependent Variable: Conflict

Table 20 - Regression Analysis. Dependent Variable: Satisfaction

Table 21 - Regression Analysis. Dependent Variable: Face Loss

Table 22 - Role of Sex on the relationship between Facework Behaviors and Satisfaction

Table 23 - Involvement in integrating facework behavior category between males and females 
Table 24 - Role of Sex on the relationship between Facework Behaviors Face Loss

Table 25 - Regression Analysis. Dependent Variable: Satisfaction - Both Sexes Included

Table 26 - Regression Analysis. Dependent Variable: Satisfaction

Table 27 - Regression Analysis. Dependent Variable: Face Loss - Both Sexes Included

Table 28 - Satisfaction between males with higher and lower conflict levels

Table 29 - Regression Analysis. Dependent Variable: Face Loss

Table 30 - Satisfaction between females with higher and lower conflict levels

Table 31 - Satisfaction between participants with higher and lower conflict levels

Table 32 - Satisfaction between males and females with lower levels of conflict

Table 33 - Satisfaction between males and females with higher levels of conflict

Table 34 - Satisfaction between males and females

Table 35 - Face loss between males with higher and lower conflict levels

Table 36 - Face loss between females with higher and lower conflict levels

Table 37 - Face loss between participants with higher and lower conflict levels

Table 38 - Face loss between males and females with lower levels of conflict

Table 39 - Face loss between males and females with higher levels of conflict

Table 40 - Face loss between males and females

Table 41 - Regression Analysis. Moderator Effect. Dependent Variable: Satisfaction Both Sexes Included

Table 42 - Regression Analysis. Moderator Effect. Dependent Variable: Face Loss Both Sexes Included

Table 43 - Regression Analysis. Moderator effect. Dependent Variable: Satisfaction

Table 44 - Regression Analysis. Moderator effect. Dependent Variable: Face Loss

Table 45 - Frequency of Facework Behavior

Table 46 - Frequency of Facework Behavior Categories

Table 47 - Facework Behaviors ordered by Mean

Table 48 - Means of Facework Behaviors Categories 


\section{List of Figures}

Figure 1 - $\quad$ Model Used for Canelon et al. (2011a)

Figure 2 - $\quad$ Model Used for Canelon et al. (2011b)

Figure 3 - $\quad$ Results from Canelon et al. (2011b)

Figure 4 - $\quad$ Research Model

Figure 5 - Interaction effect of level of the avoiding facework category on the relationship between conflict level and satisfaction for females

Figure 6 - Interaction effect of level of the integrating facework category on the relationship between conflict level and face loss for males

Figure 7 - Interaction effect of level of the avoiding facework category on the relationship between conflict level and face loss for females

Figure 8 - Frequency of Facework Behaviors

Figure 9 - $\quad$ Means of Facework Behaviors

Figure 10 - Direct Face Loss effect on Relationship Deterioration 


\section{Chapter 1 - Introduction}

Discussion is an important form of human communication-one that is essential for collaboration, cooperation, learning, and many other social activities. As is true with

other forms of communication, discussion involves the sending and receiving of messages to convey meaningful information.

Discussions involve people talking about an agreed topic in order to share ideas, explore solutions, reach agreement, come to a decision, etc. Discussions can be viewed as similar to conversations, which do not have a specific subject, and debates, which are more formal in nature.

An important aspect during a discussion or any other episode involving the interrelationships among participants, face-to-face or online, is face. Face is defined by Goffman (1967, p. 5) as "the positive social value a person effectively claims for himself by the line others assume he has taken during a particular contact." Face is considered an important factor in areas such as politeness, compliance gaining, emotional discourse, negotiations, conflicts and face-negotiation theory, among others.

Discussions can also be seen as being related (if not as closely) to other forms of human communication, including audiences, arguments, bull sessions, chats, conferences, consultations, give-and-take sessions, huddles, interrogations, interviews, lectures, meetings, negotiations, round-tables, salons, teach-ins, and teleconferences, which can be seen to differ in terms of the behaviors, emotional states, formality, mechanisms, nature of groups, and purposes involved.

Discussion always includes speech acts, and it often includes non-verbal behaviors, including gestures, facial expressions, and others. In face-to-face discussions, 
body language and voice tonality play significant roles, and may be more meaningful (in some cases) than the words that participants voice or write.

To be successful, a discussion requires participants who can create and process messages that are mutually intelligible. Participants need skills in speaking, listening, analyzing/evaluating, and questioning. They also need interpersonal skills related to making sense of and participating in social situations.

In many discussions, participants interact in one another's presence, but this is not always the case. Technology has allowed participants to be in different locations, communicating through some medium. They also may participate at different times, sending and receiving messages in an asynchronous manner.

Online discussions have become commonplace. According to Levine (2007), discussion boards are becoming a central component that goes beyond the traditional classroom setting. Palloff and Pratt (1999) mention that the interactive nature of online discussion boards facilitates a constructivist learning approach. Online discussions allow students to read each other's ideas, share their own ideas, and collaboratively expand and deepen their mutual understanding of the discussion topic (DeWert et al., 2003; Mitchell, 2003; Gunawardena, 1998; Kanuka et al., 1996). Online discussions can foster collaborative knowledge construction (Eryilmaz et al., 2009).

The success of an online discussion (or any discussion) can be thought of as the degree to which it meets the stated purpose of the discussion. A discussion intended to share ideas can be called successful to the extent that its participants wind up with many shared notions. A discussion meant to explore solutions might be considered successful if, as a group, its participants have better comprehension of what solutions might exist and how feasible they are.

In addition to these intention-related criteria for discussion success, it is possible to think about discussion success indirectly, in terms of emotional responses to the 
discussion, such as satisfaction with the process of the discussion, satisfaction with the outcomes it produced, or even how it made participants feel. Although such criteria might seem to be mere surrogates for more "objective" assessment of goal accomplishment, they reflect important aspects of the relationship between the individuals who constitute discussion groups and the discussions in which they participate.

Discussion success depends on the characteristics (traits and states) of the individuals who participate in the discussion, their interrelationships (dynamic and structural), the topic discussed, the incentives and constraints present in the discussion context, their preferences about the communication channel (text and/or audio and/or video), the type of communication (synchronous or asynchronous), the sex of the participants, and other factors.

Just to mention a few, sex influences teams' effectiveness, interaction between team members, and conversation dominance. In terms of teams' effectiveness, DeeterSchmetz, Kenney and Ramsey (2002), report that teams with members from the same sex will be more effective than teams with members from both sexes. About interaction between members, Hutson-Comeaux and Kelley (1996) found females are more prone to positive socioemotional behavior, while males are more prone to task behavior. Finally, in discussions through a computer-mediated communication channel, males tend to dominate the discussion while females' participation is limited. Results suggest that sex influences teams in diverse ways.

One important aspect of interrelationships among the discussion participants is conflict. According to Jehn and Mannix (2001, p. 238), based on Boulding (1963), conflict is defined as "the awareness by the parties involved of discrepancies, incompatible wishes, or irreconcilable desires." Even though the word conflict has a negative connotation; not all conflict is negative. According to Andriessen et al. (1996), Baker et al. (1995), Doise and Mugny (1984), Petraglia (1998), Piaget (1977), and Savery 
\& Duffy (1996) conflicts play an important role in learning because "learning is particularly effective when collaborating students encounter conflicts, engage into argumentation and manage through negotiation to produce a shared solution.” Chan et al. (1997) stated that learning needs some level of conflict and disturbance.

Studies of the influence of conflicts on team performance show mixed results. The influence of relationship conflict (awareness of interpersonal incompatibilities (Jehn, 1995)) on team performance is mostly negative (Jehn, 1997; De Jong et al., 2008; De Drey \& Weingart, 2002; Jehn, 1995; Shah \& Jehn, 1993; Canelon et al., 2011b). Task conflict (awareness of differences among group members about group's task to be performed (Jehn, 1995)) and process conflict (awareness of the controversies that show up about how task accomplishment will proceed (Jehn \& Mannix, 2001)) did not show a clear positive or negative tendency over their influence over a team's performance (De Jong et al., 2008; Gallemkamp et al., 2010; Souren \& Sumati, 2010; Jehn \& Chadwick, 1997; De Dreu \& Weingart, 2002; Hinds and Mortensen, 2005). Based on these studies, it is expected that conflicts influence online discussion outcomes but the direction and strength of the influences is not clear.

Face is carried with the individual into every social encounter and online discussion is no exception. In online discussions, face can be threatened not only by incompatibilities among participants, disagreements about which tasks are necessary, and controversies about how to perform tasks (as is the case in face-to-face discussions), but also through misunderstanding due to the limited set of cues provided by the online medium.

Face has different meanings and importance for people varies across culture. Studies by Oetzel et al. (2001, 2007), Hui and Bond (2009), and Kam and Bond (2008) show such differences. For example, Kam and Bond (2008) show that face loss accounts 
for $27 \%$ of the variance in relationship deterioration for US participants and $35 \%$ for Chinese participants.

Individuals manage their face through facework behaviors. According to Oetzel et al. (2000, p. 398) facework behaviors refer to "the communicative strategies one uses to enact self-face and to uphold, support, or challenge another person's face." For Oetzel et al. (2007), during conflict, facework behaviors can be used to resolve, exacerbate and avoid a conflict, and to threaten or protect a person's image. In total, there are eleven facework behaviors, which are grouped into three categories: integrating, avoiding, and dominating.

Based on the evidence about the benefits of online discussion, the role that conflict plays in the learning process, and the consequences from the different facework behaviors in which people engage during conflict in face-to-face interactions, the purpose of this research is to determine the influence of facework behaviors on conflict and online discussion outcomes (satisfaction and face loss), including the effect of facework behaviors on the relationship between the conflict and the outcome of online discussion teams.

All in all, the research questions in this study are: 1. Do facework behaviors matter for conflicts between participants using an online discussion board?, and 2. How do conflicts influence the performance of participants using an online discussion board? 


\section{Chapter 2 - Literature Review}

The literature review begins with a description of the main concepts and theories, which are the foundations for this study. First, the concept of face is defined and its meaning is explained with respect to its importance during conflicts. Next, FaceNegotiation Theory (Ting-Toomey, 1988) is presented. Following this, the concept of facework and the typology of facework behaviors is explained, and studies about facework behaviors are reviewed. Finally, theory about conflicts is presented, as well as results of some studies about conflicts in online discussion.

\section{1 Face}

For Deutsch (1961) "face is one of an individual's most sacred possessions" (p. 897). The origin of the concept of face is Chinese, and it has different meanings and usages across cultures to the point where by 1935, Lin Yu-tang felt that face was "impossible to define" (p. 202). Chinese face is the literal translation of lien and mien-tzu, which are sets of criteria for judging conduct (Ho, 1976). Lien represents the moral character of an individual and mien-tzu refers to the social status achieved through success in life. For Japanese, face refers to mentsu and taimen, where mentsu is similar to the Chinese mien-tzu, and taimen refers to the appearance one presents to others. In the U.S., face represents the social image presented to others (Oetzel, Ting-Toomey, Masumoto, Yokochi, Pan, Takai, \& Wilcox, 2001). Face is an important concept and has influence in diverse areas such as: politeness (e.g., Brown \& Levinson, 1987), compliance gaining (e.g., Baxter, 1984, Tracy, Craig, Smith \& Spisak, 1984), emotional discourse (e.g., Shimanoff, 1985, 1987), conflict (e.g., Oetzel et al., 2001; Oetzel \& TingToomey, 2003), and face-negotiation theory (e.g., Ting-Toomey, 1988).

Goffman (1967) is one of the first Western authors to write about face. He defined face as "the positive social value a person effectively claims for himself by the 
line others assume he has taken during a particular contact" (p. 5). For Deutsch (1961) and Goffman (1955) as well, face is carried with the individual into his/her social encounters. Brown and Levinson (1987), building on Goffman's (1967) work, define face as "the public self-image that every member wants to claim for himself" (p. 66). From the last definition, Lim (1994) states that face has three characteristics: 1. it is not private, it is public, because face is not about what one thinks about oneself, but about what one thinks others should think about oneself; 2. it is related to one's projected image which may or may not be concurrent with another's assessment of one's real self; and 3. it is defined just in terms of positive social values.

For Ting-Toomey and Kurogi (1998) face is the claimed sense of a favorable social self-worth and/or projected other/worth in social interactions. Face is a vulnerable resource, which represents an individual's claimed sense of positive image in the context of social interaction (Oetzel, Ting-Toomey, Yokochi, \& Masumoto, 2000). Face can be lost, saved, or protected, and every person wants to present and protect his/her own public images (Brown \& Levinson, 1987; Goffman, 1967; Ting-Toomey, 1988).

During conflicts, face is negotiated covertly in most cases, while people focus on more substantive issues. Face has three levels which are: affective (e.g., feelings/emotions); behavioral (facework); and cognitive (e.g., whether and how much face to give or receive) (Oetzel et al., 2007).

\subsection{Face-Negotiation Theory}

Theories and models explaining face and facework (viz.: Brown \& Levinson, 1978, 1987; Cupach \& Metts, 1994; Rogan \& Hammer, 1994; Lim \& Bowers, 1997) have limitations for the study of facework in conflict. Specifically, the models of Brown and Levinson (1978, 1987) and Lim and Bowers (1997) focus on general facework 
behaviors such as request situations, that is, politeness. These models have not been applied to conflict situations (Oetzel et al., 2000).

Face-Negotiation Theory (Ting-Toomey, 1988; Ting-Toomey \& Kurogi, 1998) argues that face is a central component of an explanatory mechanism for facework across cultures during conflicts. The basic assumptions of face-negotiation theory are: 1. people in all cultures negotiate face during communication situations; 2. face plays an important role in uncertainty situations such as conflict; and 3. situational variables influence the use of facework behaviors in interpersonal and intergroup encounters (Oetzel et al., 2000).

According to Rogan and Hammer (1994), face concerns play an important role in the understanding of face and facework because they help to determine the interests of the individual and the content of messages in terms of a specific behavioral presence. In that sense, Politeness Theory (Brown \& Levinson, 1987) focuses on others' face. Meanwhile, Face-Negotiation Theory incorporates two more face concerns which are: self-face and mutual-face. Self-face refers to the concerns for only the individual's own image. Other-face, the domain of politeness, refers to the face concerns for another's image. Finally, mutual-face is the simultaneous concern for the images of both parties.

\subsection{Facework}

Goffman (1967) defines facework as "the actions taken by a person to make whatever he is doing consistent with face" (p. 12). According to Oetzel et al. (2000) the communication behaviors or facework are defined as "the communicative strategies one uses to enact self-face and to uphold, support, or challenge another person's face” (p. 398). Lim (1994) defines facework as "the actions taken to deal with the face-wants of one and/or another" (p. 211). Oetzel et al. (2007) argue that during conflicts, facework 
can be used to resolve, exacerbate and avoid a conflict; threaten or challenge another person's position; protect a person's image; or even manage shared social identity. A concept closely related to facework is conflict style (Oetzel et al., 2000; Oetzel et al., 2007). Although equivalent, facework behaviors refer to specific strategies related to a person's claimed positive social image above and beyond a conflict situation, while conflict style involves a general pattern of behaviors used during conflicts (Oetzel et al., 2000; Oetzel et al., 2007). Moreover, conflict style can include some facework behaviors.

Oetzel et al. (2000) report a multi-stage study that identified 13 types of facework behaviors during conflicts, where the participants were asked to describe a recent conflict situation with a stranger or a best friend. These are: 1. aggression, 2. apologize, 3. avoid, 4. compromise, 5. consider the other, 6. defend self, 7. express feelings, 8. give in, 9. involve a third party, 10. pretend, 11. private discussion, 12. remain calm, and 13. talk about the problem. Later, Oetzel, Ting-Toomey, Masumoto, Yokochi, Pan, Takai, and Wilcox (2001) reduced the typology from thirteen to eleven. These eleven facework behaviors and examples are listed next (examples were extracted from transcripts of an online discussion board in Canelon et al. (2011a); only participants' names were changed to protect their real identities, everything else remains unchanged):

1. Aggression: degree to which a person tries to insult, hurt, or ridicule another person, telling the other he/she is wrong, stupid ...

Examples:

1. So you are saying...if you kill one life now as long as you save a life later it is alright? How do you know 100\% sure that it will save that life later down in the road? It is called research for a reason which means they haven't figured it out. With what you are saying is that it is okay to kill a life now so they can do their research and possibly save someone later. But, how do you know for sure? Can you have that on your conscious?

2. Hey wake up! its 2010 people. not the 60's where you would get shunned for being prego. What im saying is why some people are against stem cell is becuase one purpose is for clonning these cells and people dont want to be clonned. 
2. Problem solve: focuses on behaviors that attempt to resolve a conflict through compromising or integrating viewpoints.

Example:

I really liked Nadal's third reason for approving violent video games because at the end of the day there will always be violence everywhere in our society. It is really unavoidable so why should video games be any different?

3. Third party: involving an outside person to help to resolve the conflict.

Example:

Hey Pete, it looks like you do not understand my point. Could you ask Johanna to see if she can clarify it?

4. Apologize: admitting that you made a mistake during the conflict and telling the other about it.

Example:

I meant to put that reason under rejecting. Again sorry, I have been dealing with a family situation.

5. Defend: defending one's position without giving in.

Example:

I understand what Roger is saying. The pregnant woman has already decided to abort her baby so why not extract the cells from the embryo? It's a good point but it's still wrong. Abortion is wrong. There are other methods of extracting stem cells, taking them from embryo's should not be allowed.

6. Respect (i.e., consider the other): showing sensitivity, attentiveness, and listening to the other person.

Example:

Bringing awareness to a subject doesn't necessarily facilitate that subject. I'd like to see you expand on this subject, though! Perhaps you can convince me with empirical evidence - assuming it exists. 
7. Pretend: pretending the there is no conflict or that you are not upset or hurt by what has happened.

Example:

There is no example for this facework behavior.

8. Remain calm: trying to keep one's composure, stay calm, and unemotional during a conflict.

Example:

Like I mentioned on my other post, I think you are misinterpreting my point.

9. Give in: accommodate the other person and let them win during the conflict.

Example:

I am fine with whatever topic we choose to discuss as a group. However, I would also like to point out that I am much more comfortable with the topic on violent video games.

10. Express emotions: express how one is feeling without defending or attacking the other.

Example:

I'm not sure if this is humanly moral BUT it can be used in turn to SAVE A LIFE DOWN THE ROAD!! End a life, help someone's in the future??

11. Private discussion: refuse to talk about the problem in public.

Example:

Could we talk tonight? Call me at 888-888-8888, honestly, I do not want everybody else to read my comments to your last post. 


\subsubsection{Integrating, Avoiding, and Dominating Facework Categories}

The results of a factor analysis on facework behaviors (Oetzel et al. 2000, 2001) show three categories; integrating facework, avoiding facework, and dominating facework.

Integrating facework deals with the resolution of conflict and the preservation of the relationship (maintain self-face and other-face) (Oetzel et al., 2000; Oetzel et al., 2008). This category encompasses the following behaviors: private discussion, apologize, problem solve, remain calm, respect, and express emotions.

Avoiding facework focuses on maintaining the relationship by not directly dealing with the conflict (maintain the face of the other person) (Oetzel et al., 2000; Oetzel et al., 2008). This category refers to: third party, pretend, and give in.

Dominating facework refers to presenting a believable image with the idea to win the conflict (maintain ones-self) (Oetzel et al., 2000; Oetzel et al., 2008). This category refers to the strategies: aggression, defend, and express emotions.

The facework behavior express emotions, is related with the dominating and integrating facework strategies. For purposes of conceptual simplification, this study will consider the facework behaviors to be part of both categories.

\subsubsection{Studies about Facework}

In studies related to face and facework [Oetzel et al. (2000); Oetzel, TingToomey, Masumoto, Yokochi, Pan, Takai, \& Wilcox (2001); Oetzel \& Ting-Toomey (2003); Oetzel, Ting-Toomey, Chew-Sanchez, Harris, Wilcox \& Stumpf (2003); Oetzel et al. (2007)], the researchers gathered information asking what participants recall from a past conflict with a parent, siblings, best friends, etc. Even though it is not explicit, one might assume that they refer to conflicts during face-to-face interactions. Walsh, Gregory, Lake, and Gunawardena (2003) asked questions to students in an online learning environment based on a conflict scenario and analyzed the participants' reactions 
to a demeaning online message from another participant. Walsh et al. (2003) found that regardless of cultural heritage the majority of the study participants considered the establishment of positive face important in an online course environment. Baranova (2010) studied facework in organizational conflicts asking participants about hypothetical face-to-face situations.

\subsection{Conflicts}

Conflicts are inevitable in any team. Following from Boulding (1963), Jehn and Mannix (2001, p. 238) defines conflict as "the awareness by the parties involved of discrepancies, incompatible wishes, or irreconcilable desires". Conflicts play an important role in learning according to Andriessen et al. (1996), Baker et al. (1995), Doise and Mugny (1984), Petraglia (1998), Piaget (1977), and Savery and Duffy (1996). The latter researchers mention "learning is particularly effective when collaborating students encounter conflicts, engage into argumentation and manage through negotiation to produce a shared solution.” Jehn $(1995,1997)$ proposed that in work groups conflicts can be classified in to three types: relationship, task, and process.

1. Relationship conflict refers to an awareness of interpersonal incompatibilities, which includes affective components such as feeling tension, friction, animosity, and annoyance among members of the group (Jehn, 1995).

2. Task conflict is an awareness of the differences among group members in terms of viewpoints and opinions about the group’s tasks being performed (Jehn, 1995).

3. Process conflict (Jehn \& Mannix, 2001) refers to the controversies that arise from aspects such as how task accomplishment will proceed, for instance, when group members disagree about whose responsibility it is to complete a specific task. 
The results from different studies about conflicts and team performance are presented next, organized by the type of conflict analyzed in each study.

\subsubsection{Relationship Conflict}

The connection between relationship conflict and performance is mostly negative. Jehn (1997) interviewed two management teams and four production teams from an international household-goods moving organization and found that relationship conflict is detrimental to performance.

De Jong et al. (2008) studied the relationship between the types of conflicts and perceived team performance, and the moderating role that team virtuality has over the relationship between conflict types and perceived team performance. They defined team virtuality based on: 1 . the extent to which team members use communication media; 2. the level of use of synchronous communication media; and 3. extent to which communication media are capable of transmitting para-verbal and nonverbal aspects of communication. In their study with 276 subjects and 76 teams, they found that relationship conflict has a negative, but not significant, impact on team performance. They also found that the level of team virtuality has no significant interaction effect.

De Dreu and Weingart (2002) conducted a meta-analysis considering 30 studies about task conflict, relationship conflict, and team performance. They found a strong and negative correlation between relationship conflict and team performance. Cross-sectional studies have shown that relationship conflict negatively affects individual and group level performance, member satisfaction, and the likelihood a team will work together in the future (Jehn, 1995; Shah \& Jehn, 1993).

Canelon et al. (2011b) found that relationship conflict has a significant negative influence on online team outcome satisfaction, process satisfaction, and team cohesion; meanwhile, it did not have a significant influence on face loss. In general, all the 
studies presented here suggest that relationship conflict has a negative impact on the team performance.

\subsubsection{Task Conflict}

This type of conflict presents an interesting case because there is no consistent pattern of influence between it and online discussion outcomes. Studies that support the positive or negative influence that this type of conflict has on online discussion outcomes are presented next.

On the positive side:

1. De Jong et al. (2008) found a positive, but not significant, relationship between task conflict and perceived team performance. They also found that the level of virtuality exacerbates the positive impact of task conflict on perceived team performance.

2. Gallenkamp et al. (2010) studied the impact of task conflict on team performance. They considered virtual teams from an online game context. They found a positive and significant relationship between task conflict and team performance.

3. Souren and Sumati (2010) studied multi-cultural virtual teams and they found that in global virtual teams involved in short duration and non-repetitive group work, task conflict is more dominant than relationship conflict.

On the negative side:

1. Jehn and Chadwick (1997) found that task conflict has a negative impact on students' collocated teams performance.

2. Canelon et al. (2011b) found that task conflict negatively influenced outcome satisfaction and process satisfaction, while there was no effect on face loss or team cohesion. 
3. Jehn (1995), in a study with 26 management teams and 79 work groups from a large freight transportation firm, found that task conflict is negatively associated with performance.

4. de Dreu and Weingart (2002) found a strong and negative correlation between task conflict and team performance.

\subsubsection{Process Conflict}

De Jong et al. (2008) found a significant negative impact of process conflict over perceived team performance. The interaction effect of team virtuality over the relationship between process conflict and perceived team performance was not significant. Gallenkamp et al. (2010) also found a negative and significant effect of process conflict over team performance.

Canelon et al. (2011b) found that process conflict has a significant negative influence over outcome satisfaction and process satisfaction. Nevertheless, it did not show any influence on face loss or team cohesion. Meanwhile, Martinez-Moreno et al. (2008) found that the performance of collocated teams is improved by process conflicts.

According to Hinds and Mortensen (2005), process conflict is not as well researched as task and relationship conflict. In consequence, more studies are necessary about this type of conflict. The previous studies suggest that process conflict has a negative influence over team outcomes.

\subsection{Other factors impacting online discussion outcomes}

Conflicts and facework behaviors are not the only variables influencing online discussion outcomes. The influence of other variables such as communication medium, team size, and sex are presented next.

One factor that influences a team's performance is the communication medium. Martinez-Moreno, Gonzalez-Navarro, Zornova and Ripoll (2008) in a study with 22 face- 
to-face (FtF) teams, 22 videoconference teams (VC), and 22 computer-mediated communication (CMC) teams over a one month period found: 1 . at the first stage of the teamwork, when task conflict increases, the videoconference teams' performance diminishes; 2. the performance of FtF teams is positively influenced by task conflict and process conflict; and 3. after a period of time where the members can develop teamwork experience, relationship conflict and process conflict have a bigger negative performance impact on CMC teams than on FtF teams.

From the co-located team literature, team size also influences a team's performance. The studies of Dave (1934) and Miller (1951) suggest that a higher number of team members decreases team members' participation. Meanwhile, Thomas and Fink's (1963) study suggests that in smaller teams there are more opportunities for team members to interact with each other. Campion, Papper, and Medsker (1996) found that the larger the team, the more ineffective it is. Another problem with team size seems to be social loafing (or free riding). The studies of Johnson and Johnson (1994) and Strong and Anderson (1990) suggest that as team size increases, social loafing increases as well. Based on the previous studies, Deeter-Schmetz, Kenney and Ramsey (2002) suggest that smaller teams perform better than larger teams.

Sex plays a role in team effectiveness. Pelled (1996) found that teams with members from both sexes are positively associated with relationship conflicts. Rodelberg and Rumery (1996) state that sex also influences team decision quality. Their results suggest that team decision quality increases as the number of men in the team increases. Wood, Polek and Aiken (1985) suggest that males generate more solutions to tasks where idea generation is required, while females generate better solutions to tasks where a team's consensus is required. Deeter-Schmetz, Kenney and Ramsey (2002) mention that: 1. teams with sex diversity influence how the team members interact with each other, and 
in consequence it will influence the performance of the team, and 2. teams with members from the same sex will be more effective than teams with members from both sexes.

Sex influences the interaction between team members. Hutson-Comeaux and Kelly (1996) report that female team members are more prone to positive socioemotional behavior while males are prone to active task behavior. In terms of learning, according to Cox et al. (2000), females are associated with behaviors such as support, sharing ideas, reflection, networking, and social inclusion, and they visualize learning as a group experience; males focus more on a competitive and individualistic perspective.

Finally, in discussion between members of both sexes through a computermediated communication channel, according to Gregory (1997), males tend to dominate the discussion and the participation of the females is limited, which makes the moderating role of the instructor more prominent. 


\section{Chapter 3 - Project Background}

This chapter describes two prior studies performed involving face, facework, conflicts and online discussion, the central concepts in this study. Canelon et al. (2011a) show that sex plays a moderating role in the relationship between facework behaviors and online discussion outcomes. Canelon et al. (2011b) provides additional evidence that conflicts affect online discussion outcomes.

\subsection{Study \#1 - Canelon et al. (2011a)}

In a group of 103 undergraduate students from a western U.S. university, 50 Males, 52 Females and 1 participant of unknown sex interacted with each other through an online discussion board on which they had to write at least 6 posts (as well as fill out a survey at the end of the assignment) about a predetermined topic. The topic was chosen with the purpose of generating as much conflict as possible. The study was based on the model shown on Figure 1. Canelon et al. (2011a) report that online discussion outcomes depend on different facework behaviors, and that sex plays a moderating role.

Figure 1 - Model used for Canelon et al. (2011a)

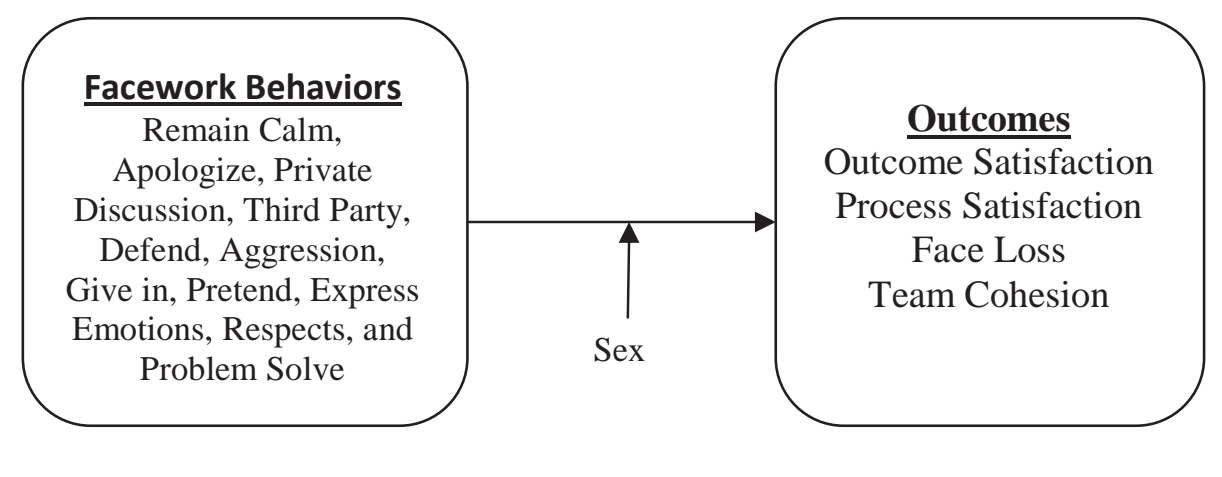

The results are shown in Table 1. They suggest a difference between males and females in terms of which facework behaviors explain variance in online discussion outcomes. 
Table 1. Regression Analysis for the Online Discussion Teams Outcome: Outcome Satisfaction

\begin{tabular}{|c|c|c|c|c|c|c|c|c|c|}
\hline \multicolumn{10}{|c|}{ Model Summary } \\
\hline & \multicolumn{2}{|c|}{ Model } & $\mathrm{R}$ & \multicolumn{2}{|c|}{ R Square } & \multicolumn{2}{|c|}{\begin{tabular}{c|l}
$\begin{array}{c}\text { Adjusted R } \\
\text { Square }\end{array}$ & $\mathrm{S}$ \\
\end{tabular}} & \multicolumn{2}{|c|}{$\begin{array}{l}\text { Std. Error of the } \\
\text { Estimate }\end{array}$} \\
\hline Male & \multicolumn{2}{|l|}{1} & $.30^{\mathrm{a}}$ & & .09 & \multicolumn{2}{|r|}{.07} & \multicolumn{2}{|r|}{.67} \\
\hline Female & \multicolumn{2}{|l|}{1} & $.28^{\mathrm{b}}$ & & .08 & \multicolumn{2}{|r|}{.06} & \multicolumn{2}{|r|}{.72} \\
\hline \multicolumn{10}{|c|}{$\begin{array}{l}\text { a. Predictors: (Constant), Express Emotions } \\
\text { b. Predictors: (Constant), Private Discussion }\end{array}$} \\
\hline \multicolumn{10}{|c|}{ ANOVA $^{c}$} \\
\hline & \multicolumn{4}{|c|}{ Model } & $\begin{array}{l}\text { Sum of } \\
\text { Squares }\end{array}$ & $\mathrm{df}$ & $\begin{array}{l}\text { Mean } \\
\text { Square }\end{array}$ & 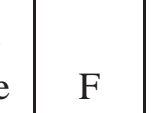 & Sig. \\
\hline \multirow[t]{3}{*}{ Male } & \multirow[t]{3}{*}{1} & \multicolumn{3}{|c|}{ Regression } & 2.08 & 1 & 2.08 & $38 \quad 4.71 \mid$ & $.04^{\mathrm{a}}$ \\
\hline & & \multicolumn{2}{|c|}{ Residual } & & 21.23 & 48 & & 44 & \\
\hline & & \multicolumn{2}{|c|}{ Total } & & 23.31 & 49 & & & \\
\hline \multirow[t]{3}{*}{ Female } & \multirow[t]{3}{*}{1} & \multicolumn{3}{|c|}{ Regression } & 2.16 & 1 & 2.16 & \begin{tabular}{l|l}
16 & 4.18 \\
\end{tabular} & $.05^{\mathrm{b}}$ \\
\hline & & \multicolumn{3}{|c|}{ Residual } & 25.85 & 50 & .52 & 52 & \\
\hline & & \multicolumn{2}{|c|}{ Total } & & 28.01 & 51 & & & \\
\hline
\end{tabular}

a. Predictors: (Constant), Express Emotions

b. Predictors: (Constant), Private Discussion

c. Dependent Variable: Outcome Satisfaction

\section{Coefficients $^{\mathrm{a}}$}

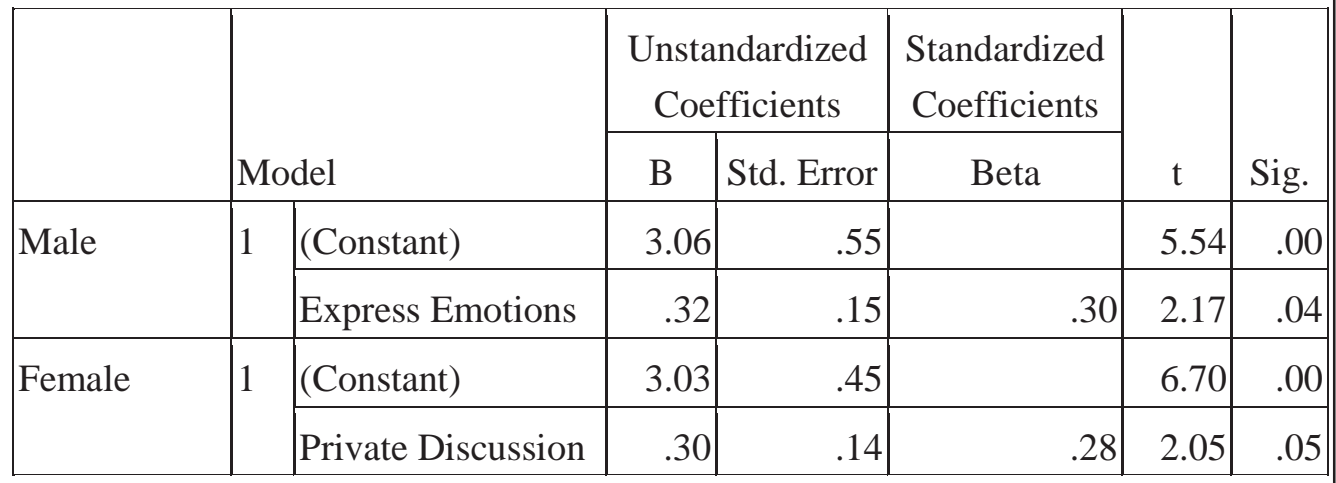

a. Dependent Variable: Outcome Satisfaction 
Table 2. Regression Analysis for the Online Discussion Teams Outcomes: Process Satisfaction

\begin{tabular}{|l|l|r|r|r|c|}
\hline \multicolumn{7}{|c|}{ Model Summary } \\
\hline & Model & \multicolumn{1}{c|}{ R } & R Square & $\begin{array}{c}\text { Adjusted R } \\
\text { Square }\end{array}$ & $\begin{array}{c}\text { Std. Error of the } \\
\text { Estimate }\end{array}$ \\
\hline Male & 1 & $.31^{\mathrm{a}}$ & .10 & .08 & 1.09 \\
\hline
\end{tabular}

a. Predictors: (Constant), Third Party

\begin{tabular}{|c|c|c|c|c|c|c|c|}
\hline \multicolumn{8}{|c|}{ ANOVA $^{\mathbf{b}}$} \\
\hline & \multicolumn{2}{|c|}{ Model } & $\begin{array}{c}\text { Sum of } \\
\text { Squares }\end{array}$ & $\mathrm{df}$ & $\begin{array}{l}\text { Mean } \\
\text { Square }\end{array}$ & $\mathrm{F}$ & Sig. \\
\hline \multirow[t]{3}{*}{ Male } & \multirow[t]{3}{*}{1} & Regression & 6.21 & 1 & 6.21 & 5.25 & $.03^{\mathrm{a}}$ \\
\hline & & Residual & 56.73 & 48 & 1.18 & & \\
\hline & & Total & 62.94 & 49 & & & \\
\hline
\end{tabular}

a. Predictors: (Constant), Third Party

b. Dependent Variable: Process Satisfaction

\section{Coefficients $^{\mathrm{a}}$}

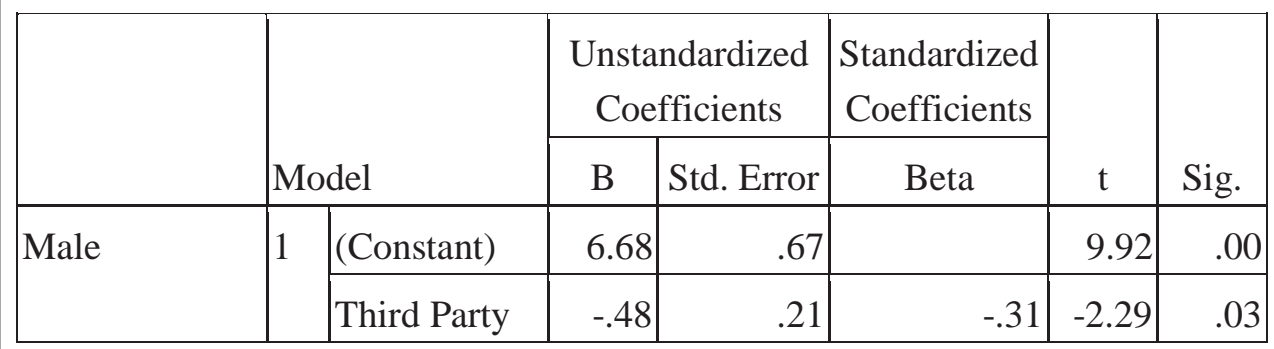

a. Dependent Variable: Process Satisfaction

Results from Table 1 show that for males, the facework behaviors related to the different outcomes are more direct and confrontational, while for females the facework behaviors are less confrontational. Express emotions is the facework behavior related to outcome satisfaction in males $\left(\mathrm{R}^{2}=.09\right)$, while it is private discussion for females $\left(\mathrm{R}^{2}=\right.$ .08). This result suggest that males are more satisfied if they are able to express their 
emotions in the middle of the conflict "in front" of all team members, while females prefer to deal with the conflict in private.

In the case of process satisfaction (see Table 2), the difference between sexes is more evident. This outcome was only related negatively to third party for males $\left(\mathrm{R}^{2}=\right.$ 0.10); no facework behavior was related to process satisfaction for females. For males the higher the level of third party involvement, the lower the process satisfaction is. The result suggested that males prefer a more direct, faster approach overlooking the intervention of a third person.

Face loss (see Table 3) represents an interesting outcome for females, where aggression $\left(\mathrm{R}^{2}=0.26\right)$ predicts a high percentage of the variance in comparison with the other outcomes. From the IT perspective, it might be interesting to develop an artifact capable of detecting aggression in interactions involving female participants in an online discussion team to reduce face loss.

Based on the results from Table 4, pretend is related negatively to team cohesion for males $\left(\mathrm{R}^{2}=.08\right)$, and it is related to private discussion for females $\left(\mathrm{R}^{2}=.08\right)$. In this case, the more the males pretend, the lower the team cohesion. This is aligned with the case of outcome satisfaction, where males prefer a more confrontational process. For females, as in the case of outcome satisfaction, a higher level of private discussion results in higher team cohesion.

These results point out the role sex plays in team behavior and are similar to those reported by Pelled (1996), Wood et al. (1985), and Deeter-Schmetz (2002). Results are aligned with the findings from Hutson-Comeaux and Kelly (1996), who found that females are prone to positive socioemotional behavior while males prefer active task behaviors. In addition, females are associated with behaviors such as support, sharing ideas, reflection, and social inclusion, while males focus on competitive and individualist perspectives (Cox et al., 2000). 
Table 3. Regression Analysis for the Online Discussion Teams Outcomes: Face Loss

\begin{tabular}{|c|c|c|c|c|c|}
\hline \multicolumn{6}{|c|}{ Model Summary } \\
\hline & Model & $\mathrm{R}$ & R Square & $\begin{array}{c}\text { Adjusted R } \\
\text { Square }\end{array}$ & $\begin{array}{l}\text { Std. Error of the } \\
\text { Estimate }\end{array}$ \\
\hline Female & 1 & $.51^{\mathrm{a}}$ & .26 & .24 & 1.14 \\
\hline
\end{tabular}

a. Predictors: (Constant), Aggression

\begin{tabular}{|c|c|c|c|c|c|c|c|}
\hline \multicolumn{8}{|c|}{ ANOVA $^{\mathbf{b}}$} \\
\hline & \multicolumn{2}{|c|}{ Model } & $\begin{array}{l}\text { Sum of } \\
\text { Squares }\end{array}$ & $\mathrm{df}$ & $\begin{array}{l}\text { Mean } \\
\text { Square }\end{array}$ & $\mathrm{F}$ & Sig. \\
\hline \multirow[t]{3}{*}{ Female } & \multirow[t]{3}{*}{1} & Regression & 22.66 & 1 & 22.66 & 17.49 & $.00^{\mathrm{a}}$ \\
\hline & & Residual & 64.78 & 50 & 1.30 & & \\
\hline & & Total & 87.44 & 51 & & & \\
\hline
\end{tabular}

a. Predictors: (Constant), Aggression

b. Dependent Variable: Face Loss

\section{Coefficients $^{\mathrm{a}}$}

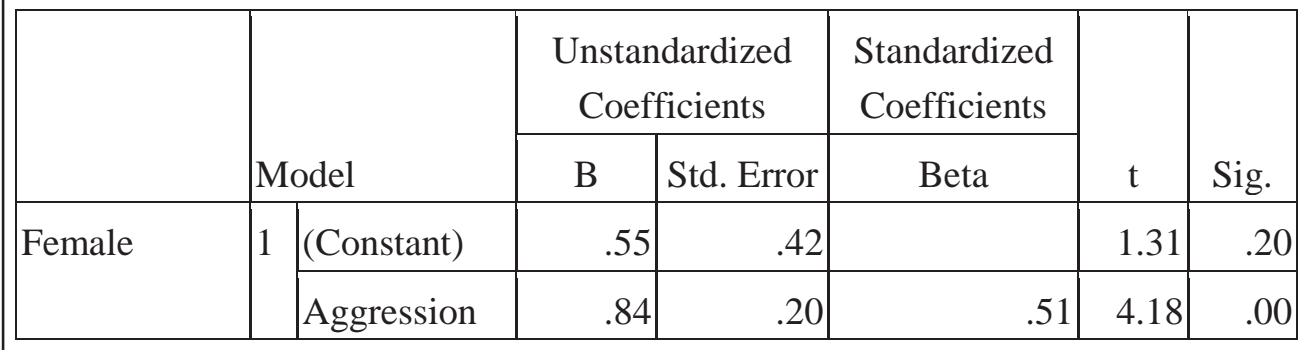

a. Dependent Variable: Face Loss 
Table 4. Regression Analysis for the Online Discussion Teams Outcomes: Team Cohesion

\begin{tabular}{|l|l|r|r|r|r|}
\hline \multicolumn{7}{|c|}{ Model Summary } \\
\hline & Model & \multicolumn{1}{|c|}{ R } & R Square & $\begin{array}{c}\text { Adjusted R } \\
\text { Square }\end{array}$ & $\begin{array}{c}\text { Std. Error of the } \\
\text { Estimate }\end{array}$ \\
\hline Male & 1 & $.29^{\mathrm{a}}$ & .08 & .06 & 1.16 \\
\hline Female & 1 & $.28^{\mathrm{b}}$ & .08 & .06 & 1.63 \\
\hline
\end{tabular}

a. Predictors: (Constant), Pretend

b. Predictors: (Constant), Private Discussion

\begin{tabular}{|c|c|c|c|c|c|c|c|}
\hline \multicolumn{8}{|c|}{ ANOVA $^{c}$} \\
\hline & \multicolumn{2}{|c|}{ Model } & $\begin{array}{l}\text { Sum of } \\
\text { Squares }\end{array}$ & $\mathrm{df}$ & $\begin{array}{l}\text { Mean } \\
\text { Square }\end{array}$ & $\mathrm{F}$ & Sig. \\
\hline \multirow[t]{3}{*}{ Male } & \multirow[t]{3}{*}{1} & Regression & 5.75 & 1 & 5.75 & 4.29 & $.04^{\mathrm{a}}$ \\
\hline & & Residual & 64.25 & 48 & 1.34 & & \\
\hline & & Total & 69.99 & 49 & & & \\
\hline \multirow[t]{3}{*}{ Female } & \multirow[t]{3}{*}{1} & Regression & 11.64 & 1 & 11.64 & 4.36 & $.04^{\mathrm{b}}$ \\
\hline & & Residual & 133.60 & 50 & 2.67 & & \\
\hline & & Total & 145.24 & 51 & & & \\
\hline
\end{tabular}

a. Predictors: (Constant), Pretend

b. Predictors: (Constant), Private Discussion

c. Dependent Variable: Team Cohesion

Coefficients $^{\mathrm{a}}$

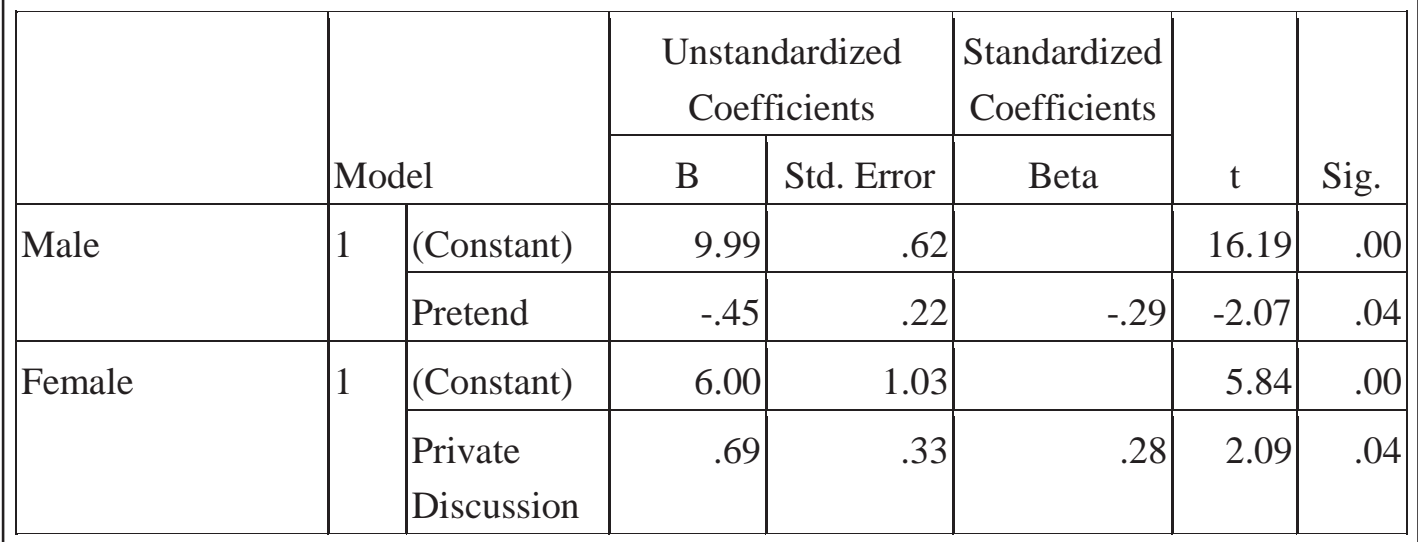

a. Dependent Variable: Team Cohesion 
3.2 Study \#2 - Canelon et al. (2011b)

In an iteration of study \#1, Canelon et al. (2011b) studied a group of 69 undergraduate students from a western U.S. university that used an online discussion board to discuss a controversial topic. This study based on the model shown in Figure 2, found that of the three types of conflicts, task conflict $(\mathrm{M}=2.58, \mathrm{SD}=1.22)$ is the one with the highest scores, followed by process conflict $(\mathrm{M}=1.94, \mathrm{SD}=1.17)$, and relationship conflict $(\mathrm{M}=1.81, \mathrm{SD}=1.05)$. In general terms, the three types of conflicts negatively influenced the team outcomes, as is described next.

Figure 2 - Model used for Canelon et al. (2011b)

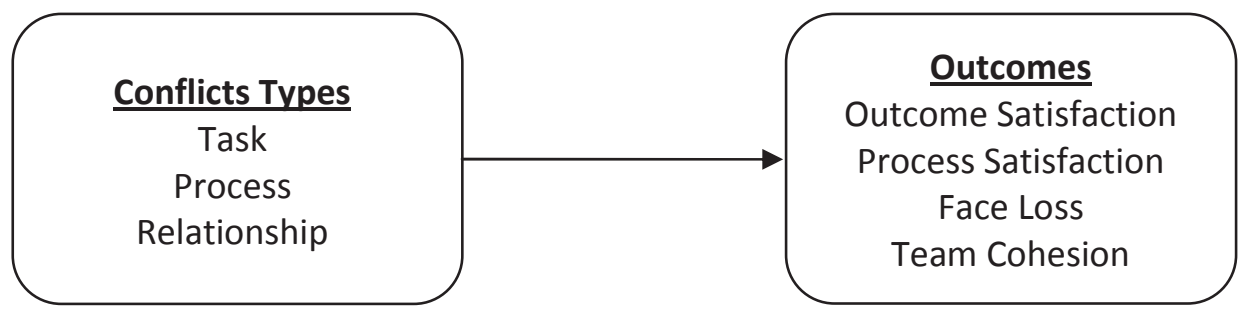

Task Conflict

Participants with task conflict scores below the mean $(\mathrm{M}=2.58, \mathrm{SD}=1.22)$ experience higher outcome satisfaction $(\mathrm{M}=4.55, \mathrm{SE}=.11)$ than participants with task conflict scores above or equal to the mean $(\mathrm{M}=3.87, \mathrm{SE}=.23)$. This difference is significant $t(30.22)=2.66, p<0.05$. It represents a medium-sized effect $r=0.44$. See Table 5.

Table 5. Satisfaction between participants with higher and lower task conflict

\begin{tabular}{|l|c|c|c|c|c|}
\hline \multicolumn{1}{|c|}{ Group } & Mean & SD & $t$ & $d f$ & $\begin{array}{c}P \text { value } \\
(2 \text {-tailed })\end{array}$ \\
\hline $\begin{array}{l}\text { Participants with task conflict level below } \\
\text { the mean }\end{array}$ & 4.55 & 0.11 & 2.66 & 30.22 & $<.05$ \\
\cline { 1 - 3 } $\begin{array}{l}\text { Participants with task conflict level above } \\
\text { or equal the mean }\end{array}$ & 3.87 & 0.23 & 23 & \\
\hline
\end{tabular}

Participants with task conflict scores below the mean experience more process satisfaction $(\mathrm{M}=5.79, \mathrm{SE}=.21)$ than participants with task conflict scores above or 
equal to the mean $(\mathrm{M}=4.98, \mathrm{SE}=.25)$. This difference is significant $t(43)=-2.48$, $p<0.05$. It represents a medium-sized effect $r=0.35$. See Table 6 .

Table 6. Process Satisfaction between participants with higher and lower task conflict

\begin{tabular}{|l|c|c|c|c|c|}
\hline \multicolumn{1}{|c|}{ Group } & Mean & SD & $t$ & $d f$ & $\begin{array}{c}P \text { value } \\
\text { (2-tailed) }\end{array}$ \\
\hline $\begin{array}{l}\text { Participants with task conflict level below } \\
\text { the mean }\end{array}$ & 5.79 & 0.21 & \multirow{2}{*}{-2.48} & 43 & $<.05$ \\
\cline { 1 - 4 } $\begin{array}{l}\text { Participants with task conflict level above } \\
\text { or equal the mean }\end{array}$ & 4.98 & 0.25 & & & \\
\hline
\end{tabular}

Participants with task conflict scores below the mean experience more face loss $(\mathrm{M}=1.43, \mathrm{SE}=.17)$ than participants with task conflict scores above or equal to the mean $(\mathrm{M}=1.33, \mathrm{SE}=.10)$, but this difference is not significant $t(43)=-.49, p>0.05$. See Table 7.

Table 7. Face Loss between participants with higher and lower task conflict

\begin{tabular}{|l|c|c|c|c|c|}
\hline \multicolumn{1}{|c|}{ Group } & Mean & SD & $t$ & $d f$ & $\begin{array}{c}P \text { value } \\
\text { (2-tailed) }\end{array}$ \\
\hline $\begin{array}{l}\text { Participants with task conflict level below } \\
\text { the mean }\end{array}$ & 1.43 & 0.17 & \multirow{2}{*}{-0.49} & 43 & $>.05$ \\
\cline { 1 - 4 } $\begin{array}{l}\text { Participants with task conflict level above } \\
\text { or equal the mean }\end{array}$ & 1.33 & 0.10 & & \\
\hline
\end{tabular}

Participants with task conflict scores below the mean experience more team cohesion $(\mathrm{M}=9.34, \mathrm{SE}=.14)$ than participants with task conflict scores above or equal to the mean $(\mathrm{M}=8.67, \mathrm{SE}=.34)$, but this difference is not significant $t(43)=-1.84$, $p>0.05$. See Table 8 .

Table 8. Team Cohesion between participants with higher and lower task conflict

\begin{tabular}{|c|c|c|c|c|c|}
\hline Group & Mean & SD & $t$ & $d f$ & $\begin{array}{l}P \text { value } \\
\text { (2-tailed) }\end{array}$ \\
\hline $\begin{array}{l}\text { Participants with task conflict level below } \\
\text { the mean }\end{array}$ & 9.34 & 0.14 & \multirow{2}{*}{-1.84} & \multirow{2}{*}{43} & \multirow{2}{*}{$>.05$} \\
\hline $\begin{array}{l}\text { Participants with task conflict level above } \\
\text { or equal the mean }\end{array}$ & 8.67 & 0.34 & & & \\
\hline
\end{tabular}


In general, task conflict negatively influences outcome satisfaction and process satisfaction. Meanwhile, there is no effect on either face loss or team cohesion.

Relationship Conflict

Participants with relationship conflict scores below the mean $(\mathrm{M}=1.81$, $\mathrm{SD}=1.05)$ experience more outcome satisfaction $(\mathrm{M}=4.53, \mathrm{SE}=.11)$ than participants with relationship conflict scores above or equal to the mean $(\mathrm{M}=3.63$, $\mathrm{SE}=.27)$. This difference is significant $t(20.45)=-3.61, p<0.05$. It represents a large-sized effect $r=0.62$. See Table 9 .

Table 9. Satisfaction between participants with higher and lower relationship conflict

\begin{tabular}{|c|c|c|c|c|c|}
\hline Group & Mean & SD & $t$ & $d f$ & $\begin{array}{l}P \text { value } \\
\text { (2-tailed) }\end{array}$ \\
\hline $\begin{array}{l}\text { Participants with relationship conflict } \\
\text { level below the mean }\end{array}$ & 4.53 & 0.11 & \multirow{2}{*}{-3.61} & \multirow{2}{*}{20.45} & \multirow{2}{*}{$<.05$} \\
\hline $\begin{array}{l}\text { Participants with relationship conflict } \\
\text { level above or equal the mean }\end{array}$ & 3.63 & 0.27 & & & \\
\hline
\end{tabular}

Participants with relationship conflict scores below the mean experience more process satisfaction $(\mathrm{M}=5.87, \mathrm{SE}=.17)$ than participants with relationship conflict scores above or equal to the mean $(\mathrm{M}=4.53, \mathrm{SE}=.26)$. This difference is significant $t$ $(43)=-4.46, p<0.05$. It represents a large-sized effect $r=0.57$. See Table 10 .

Table 10. Process Satisfaction between participants with higher and lower relationship conflict

\begin{tabular}{|c|c|c|c|c|c|}
\hline Group & Mean & SD & $t$ & $d f$ & $\begin{array}{l}P \text { value } \\
\text { (2-tailed) }\end{array}$ \\
\hline $\begin{array}{l}\text { Participants with relationship conflict } \\
\text { level below the mean }\end{array}$ & 5.87 & 0.17 & \multirow{2}{*}{-4.46} & \multirow{2}{*}{43} & \multirow{2}{*}{$<.05$} \\
\hline $\begin{array}{l}\text { Participants with relationship conflict } \\
\text { level above or equal the mean }\end{array}$ & 4.53 & 0.26 & & & \\
\hline
\end{tabular}

Participants with relationship conflict scores below the mean experience less face loss $(\mathrm{M}=1.24, \mathrm{SE}=.11)$ than participants with relationship conflict scores above or equal to the mean $(\mathrm{M}=1.63$, SE $=.18)$, but this difference is not significant $t(43)=1.89$, $p>0.05$. See Table 11 . 
Table 11. Face Loss between participants with higher and lower relationship conflict

\begin{tabular}{|c|c|c|c|c|c|}
\hline Group & Mean & SD & $t$ & $d f$ & $\begin{array}{l}P \text { value } \\
\text { (2-tailed) }\end{array}$ \\
\hline $\begin{array}{l}\text { Participants with relationship conflict } \\
\text { level below the mean }\end{array}$ & 1.24 & 0.11 & \multirow{2}{*}{1.89} & \multirow{2}{*}{43} & \multirow{2}{*}{$>.05$} \\
\hline $\begin{array}{l}\text { Participants with relationship conflict } \\
\text { level above or equal the mean }\end{array}$ & 1.63 & 0.18 & & & \\
\hline
\end{tabular}

Participants with relationship conflict scores below the mean experience more team cohesion $(\mathrm{M}=9.47, \mathrm{SE}=.11)$ than participants with relationship conflict scores above or equal to the mean $(\mathrm{M}=8.18, \mathrm{SE}=.42)$. This difference is significant $t(43)=-$ 3.83, $p<0.05$. It represents a large-sized effect $r=0.50$. See Table 12 .

Table 12. Team Cohesion between participants with higher and lower relationship conflict

\begin{tabular}{|c|c|c|c|c|c|}
\hline Group & Mean & SD & $t$ & $d f$ & $\begin{array}{l}P \text { value } \\
\text { (2-tailed) }\end{array}$ \\
\hline $\begin{array}{l}\text { Participants with relationship conflict } \\
\text { level below the mean }\end{array}$ & 9.47 & 0.11 & \multirow{2}{*}{-3.83} & \multirow{2}{*}{43} & \multirow{2}{*}{$<.05$} \\
\hline $\begin{array}{l}\text { Participants with relationship conflict } \\
\text { level above or equal the mean }\end{array}$ & 8.18 & 0.42 & & & \\
\hline
\end{tabular}

In general, relationship conflict negatively influenced outcome satisfaction, process satisfaction and team cohesion. Relationship conflict did not have a significant influence over face loss.

Process Conflict

Participants with process conflict scores below the mean experience more outcome satisfaction $(\mathrm{M}=4.46, \mathrm{SE}=.14)$ than participants with process conflict scores above or equal to the mean $(\mathrm{M}=3.85$, $\mathrm{SE}=.24)$. This difference is significant $t(43)=$ $-2.34, p<0.05$. It represents a medium-sized effect $r=0.34$. See Table 13 .

Table 13. Satisfaction between participants with higher and lower process conflict

\begin{tabular}{|l|c|c|c|c|c|}
\hline \multicolumn{1}{|c|}{ Group } & Mean & SD & $t$ & $d f$ & $\begin{array}{c}P \text { value } \\
\text { (2-tailed) }\end{array}$ \\
\hline $\begin{array}{l}\text { Participants with process conflict level } \\
\text { below the mean }\end{array}$ & 4.46 & 0.14 & \multirow{2}{*}{-2.34} & 43 & $<.05$ \\
\cline { 1 - 5 } $\begin{array}{l}\text { Participants with process conflict level } \\
\text { above or equal the mean }\end{array}$ & 3.85 & 0.24 & & \\
\hline
\end{tabular}


Participants with process conflict scores below the mean experience more process satisfaction $(\mathrm{M}=5.79, \mathrm{SE}=.19)$ than participants with process conflict scores above or equal to the mean $(\mathrm{M}=4.79, \mathrm{SE}=.27)$. This difference is significant $t(43)=-$ 3.13, $p<0.05$. It represents a medium-sized effect $r=0.43$. See Table 14 .

Table 14. Process Satisfaction between participants with higher and lower process conflict

\begin{tabular}{|l|c|c|c|c|c|}
\hline \multicolumn{1}{|c|}{ Group } & Mean & SD & $t$ & $d f$ & $\begin{array}{c}P \text { value } \\
(2 \text {-tailed })\end{array}$ \\
\hline $\begin{array}{l}\text { Participants with process conflict level } \\
\text { below the mean }\end{array}$ & 5.79 & 0.19 & \multirow{2}{*}{-3.13} & 43 & $<.05$ \\
\cline { 1 - 4 } $\begin{array}{l}\text { Participants with process conflict level } \\
\text { above or equal the mean }\end{array}$ & 4.79 & 0.27 & & & \\
\hline
\end{tabular}

Participants with process conflict scores below the mean experience less face loss $(\mathrm{M}=1.24, \mathrm{SE}=.10)$ than participants with process conflict scores above or equal to the mean $(\mathrm{M}=1.59, \mathrm{SE}=.20)$, but this difference is not significant $t(25.32)=1.60, \mathrm{p}>0.05$. See Table 15.

Table 15. Face Loss between participants with higher and lower process conflict

\begin{tabular}{|l|c|c|c|c|c|}
\hline \multicolumn{1}{|c|}{ Group } & Mean & SD & $t$ & $d f$ & $\begin{array}{c}P \text { value } \\
(2 \text {-tailed })\end{array}$ \\
\hline $\begin{array}{l}\text { Participants with process conflict level } \\
\text { below the mean }\end{array}$ & 1.24 & 0.10 & \multirow{2}{*}{1.60} & 25.32 & $>.05$ \\
\cline { 1 - 4 } $\begin{array}{l}\text { Participants with process conflict level } \\
\text { above or equal the mean }\end{array}$ & 1.59 & 0.20 & & \\
\hline
\end{tabular}

Participants with process conflict scores below the mean experience more team cohesion $(\mathrm{M}=9.35, \mathrm{SE}=.11)$ than participants with process conflict scores above or equal to the mean $(\mathrm{M}=8.51, \mathrm{SE}=.41)$. This difference is significant $t(19.66)=-1.96$, $p<0.05$. It represents a medium-sized effect $r=0.40$. See Table 16 . 
Table 16. Team Cohesion between participants with higher and lower process conflict

\begin{tabular}{|l|c|c|c|c|c|}
\hline \multicolumn{1}{|c|}{ Group } & Mean & SD & $t$ & $d f$ & $\begin{array}{c}P \text { value } \\
\text { (2-tailed) }\end{array}$ \\
\hline $\begin{array}{l}\text { Participants with process conflict level } \\
\text { below the mean }\end{array}$ & 9.35 & 0.11 & \multirow{2}{*}{-1.96} & 19.66 & $<.05$ \\
\cline { 1 - 5 } \\
$\begin{array}{l}\text { Participants with process conflict level } \\
\text { above or equal the mean }\end{array}$ & 8.51 & 0.41 & & \\
\hline
\end{tabular}

In general, process conflict negatively influenced outcome satisfaction and process satisfaction, while it did not influence either face loss or team cohesion. A summary of results from Canelon et al. (2011b) are shown in Figure 3.

Figure 3 - Results from Canelon et al. (2011b)

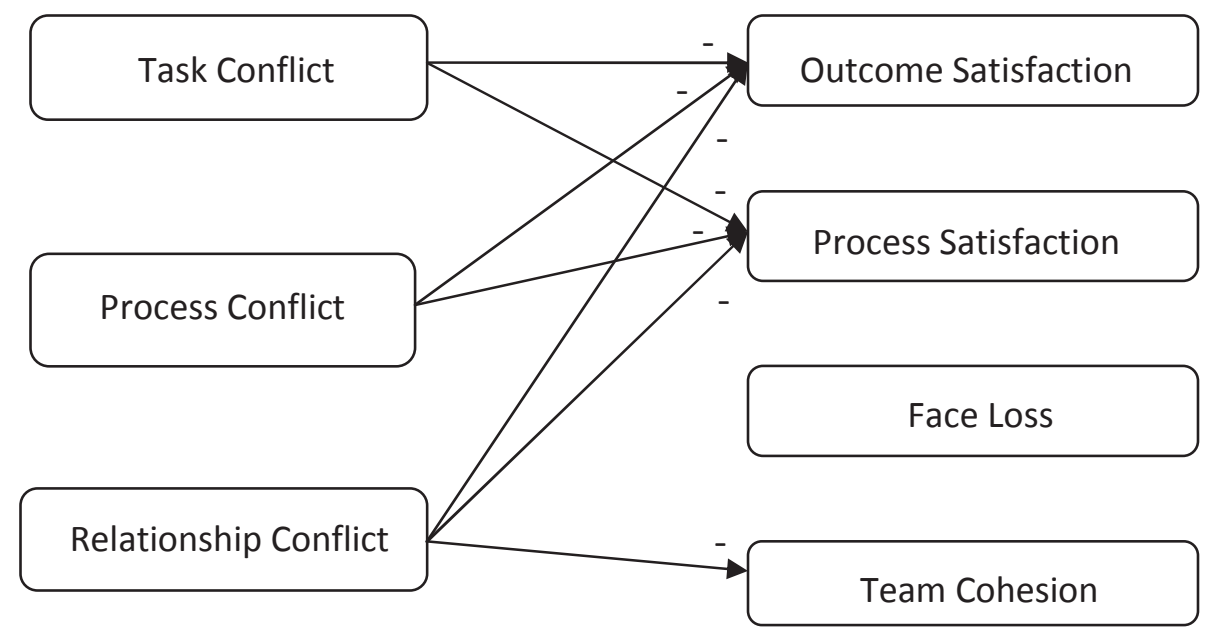

Results Analysis

A possible explanation for the low level of conflict between the participants comes from Wakefield, Leidner, and Garrison (2008). They proposed a model of leadership, conflict and performance in virtual teams based on the channel expansion theory from Carlson and Zmud (1999), and found support for their hypothesis that stated that the greater the use of communication technology among virtual team members, the less the task conflict, relational conflict, and process conflict. In this current study, the participants were instructed to interact with each other only through the online discussion 
tool. De Jong et al. (2008) also found a relatively low mean for relationship conflict, task conflict, and process conflict with 2.1, 2.4, and 2.0, respectively on a 1 to 5 scale.

The fact that task conflict is higher than relationship conflict is supported by the findings from Souren and Sumati (2010), who studied multi-cultural virtual teams and found that in global virtual teams, involved in short duration and non-repetitive group work, task conflict was more dominant than relationship conflict. They did not consider process conflict.

There are mixed results about the direction of the relationship between task conflict, relationship conflict, and process conflict with online team outcomes. In a study about conflict, culture and performance in virtual teams, Gallenkamp et al. (2010) found that task conflict is positively related to performance in virtual teams. On the contrary, Canelon et al. (2011b) found that task conflict is negatively related to two of the four outcome variables measured (outcome satisfaction and process satisfaction). Gallenkamp et al. (2010) also found that process conflict in a virtual team is negatively related to team performance. In this case, the results of Canelon et al. (2011b) support the Gallenkamp et al. (2010) findings. Gallenkamp et al. (2010) did not consider relationship conflict. In the de Jong, Schalk, and Cur eu (2008) study, the authors studied virtual communication, conflicts and performance in teams, and they did not find a significant negative relation between relationship conflict and team performance, even though they found a negative relation between them. De Jong et al. (2008) did not find a significant positive relationship between task conflict and team performance, even though they found a positive impact between them. Finally, they found a significant negative relationship between process conflict and task performance. The Canelon et al. (2011b) results support the previous findings about the negative relationship between process conflict and team performance. Meanwhile, they do not support the findings related to the positive relationship between task conflict and team performance. 
Steiner (1972) and Summers, Coffelt, and Horton (1988) argue that group cohesion influences the performance of teams. Similarly, de Dreu and Weingart (2002) also stated in their meta-analysis that outcome satisfaction is related to team cohesion (they only considered relationship conflict and task conflict). In Canelon et al. (2011b), a partial correlation keeping the three types of conflicts constant, found that outcome satisfaction $(r=.51, p<0.05)$ and process satisfaction $(r=.60, p<0.05)$ are related to team cohesion. Out of the three types of conflicts, process conflict was the one that most influenced the positive relationship between outcome satisfaction and process satisfaction with team cohesion, keeping task conflict and relationship conflict constant. De Dreu and Weingart (2002) hypothesized that relationship conflict will impact team cohesion more than task conflict based on the results of their meta-analysis where they found that relationship conflict is more disruptive than task conflict in terms of outcome satisfaction. Canelon et al. (2011b), found that the scores for outcome satisfaction and process satisfaction were lower for participants with relationship conflict above the mean than for participants with task conflict above the mean.

A partial correlation between the four outcomes, keeping constant the three types of conflict, found that even though face loss was not significantly related to any one of the other three outcomes, it had the expected negative impact on them. The type of conflict that most influences the negative relationship between face loss and the other three outcomes was process conflict. Again, the relationships were not significant but showed negative impact.

Even though the differences for the face loss mean between the participants with conflict below and above the average conflict were not significant for any of the three types of conflict, face loss was higher for participants with higher process conflict, and was also higher for participants with higher relationship conflict $(p=0.06)$, which suggests 
a positive relationship between conflicts and face loss. As a consequence, the low scores for face loss can be a product of the low conflict scores between the participants. 


\section{Chapter 4 - Research Design}

This chapter explains the research in terms of research design, research model, independent and dependent variables, hypotheses, data analyses and implementation procedures. The research questions answered in this study are: 1 . Do facework behaviors matter for conflicts between participants using an online discussion board?, and 2. How do conflicts influence the performance of participants using an online discussion board?

\subsection{Field Experiment}

This research is categorized as a one group relational design (Robson, 2002). Figure 4 depicts the research model.

Figure 4 - Research Model

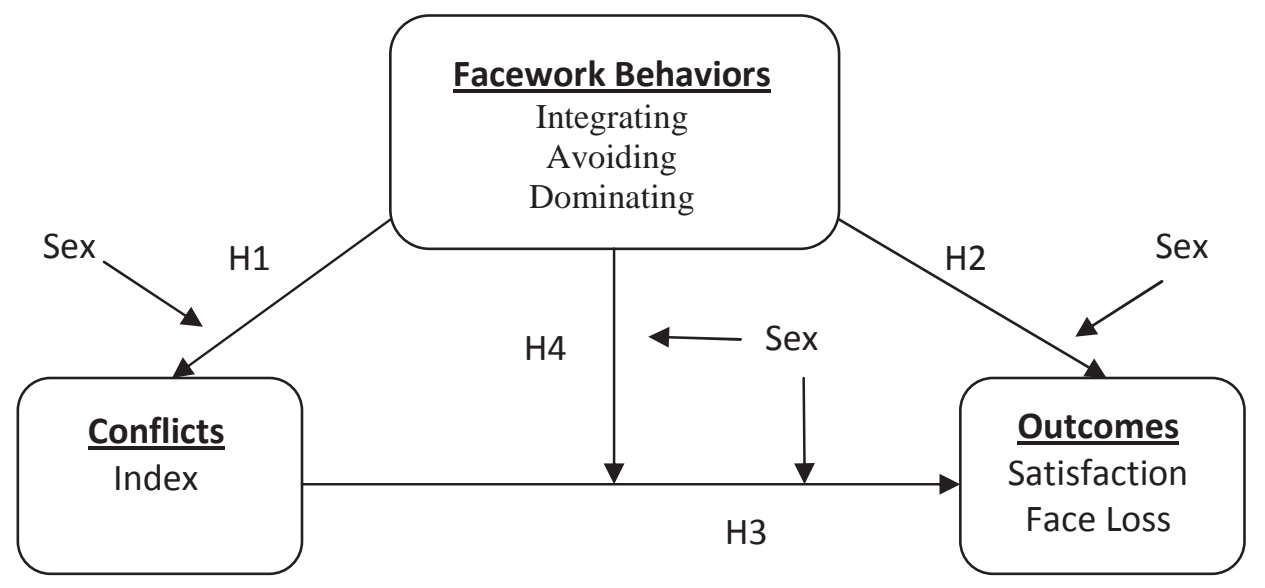

\subsection{Independent and Dependent Variables}

The independent variables are the index of conflicts based on the measurement of the type three types of conflicts: task conflict, process conflict, and relationship conflict, and the eleven facework behaviors: 1. remain calm; 2. apologize; 3. private discussion; 4. third party; 5. defend; 6. aggression; 7. give in; 8. pretend; 9. express emotions; 10. respect; and 11. problem solve, grouped by the integrating, avoiding, and dominating facework categories. The dependent variables are face loss and the index of satisfaction 
based on the measurement of outcome satisfaction, process satisfaction, and team cohesion outcomes. Two previous studies, Canelon et al. (2011a) and Canelon et al. (2011b) were performed that help to mitigate possible threats to internal and construct validity, as well as to ensure the reliability of the different measures used in this study.

The independent variables refer to the index of conflict and the three categories of facework behaviors. The facework behaviors in Canelon et al. (2011a) were measured with a reduced version of the original instrument, with 33 out of the original 63 questions, extracted from Ting-Toomey and Oetzel (2001). Canelon et al. (2011b) used the 63 questions from Ting-Toomey and Oetzel (2001). This longer version of the facework behaviors instrument is used in this study. Some items from the original version of the Ting-Toomey and Oetzel survey were adapted to an online setting and to the nature of the assignment that the participants did. For example, the original question "I waited until we were by ourselves to talk about the problem" was updated to "I waited until we through a different private communication channel were able to talk about the problem." Table 17 shows the Cronbach's alpha scores for Ting-Toomey and Oetzel (2001), Canelon et al. (2011a), Canelon et al. (2011b) and for this study.

Table 17. Facework behaviors' reliability scores

\begin{tabular}{|l|c|c|c|c|}
\hline & $\begin{array}{c}\text { Ting- } \\
\text { Toomey \& } \\
\text { Oetzel } \\
(2001)\end{array}$ & $\begin{array}{c}\text { Canelon et } \\
\text { al. (2011a) }\end{array}$ & $\begin{array}{c}\text { Canelon et } \\
\text { al. (2011b) }\end{array}$ & $\begin{array}{c}\text { Current } \\
\text { Study }\end{array}$ \\
\hline 1. Remain calm & .68 & .62 & .64 & .59 \\
\hline 2. Apologize & .82 & .63 & .80 & .85 \\
\hline 3. Private Discussion & .64 & .52 & .60 & .63 \\
\hline 4. Third Party & .81 & .67 & .65 & .78 \\
\hline 5. Defend & .82 & .49 & .63 & .71 \\
\hline 6. Aggression & .89 & .82 & .90 & .90 \\
\hline 7. Give in & .69 & .67 & .70 & .62 \\
\hline 8. Pretend & .75 & .70 & .72 & .74 \\
\hline 9. Express Emotions & .70 & .71 & .68 & .76 \\
\hline 10. Respect & .79 & .57 & .80 & .76 \\
\hline 11. Problem Solve & .89 & .61 & .77 & .81 \\
\hline
\end{tabular}


Every type of conflict was measured with three items, each assessed on a 7-point Likert scale ( $1=$ Not at all, 7 = A lot), from Jehn and Mannix (2001). The Cronbach's alphas for every type of conflict in Jehn and Mannix (2001), Canelon et al. (2011b) and this study are shown in Table 18. Some minor changes were made to the original questions. For instance, the original question "How much emotional conflict is there in your work group?" was replaced by "How much emotional conflict was there among members of your online discussion team?"

Table 18. Conflicts Types' reliabilities indexes

\begin{tabular}{|l|c|c|c|}
\hline & $\begin{array}{c}\text { Jehn \& } \\
\text { Mannix } \\
(2001)\end{array}$ & $\begin{array}{c}\text { Canelon et } \\
\text { al. (2011b) }\end{array}$ & $\begin{array}{c}\text { Current } \\
\text { Study }\end{array}$ \\
\hline Relationship Conflict & .94 & .80 & .83 \\
\hline Task Conflict & .94 & .75 & .80 \\
\hline Process Conflict & .93 & .83 & .82 \\
\hline
\end{tabular}

Outcome satisfaction refers to the participants' degree of satisfaction with the teamwork process. Four items, each assessed on a 5-point Likert scale (1=Strongly Disagree, 5=Strongly Agree), were extracted from Liu, Magjuka, and Lee (2008) where 208 students from an MBA program were grouped in teams to work on an online assignment. The Cronbach's alpha for perceived outcome satisfaction in the Liu et al. (2008) study was $\alpha=.72$, in the Canelon et al. (2011a) study it was $\alpha=.82$, for the Canelon et al. (2011b) study it was $\alpha=.91$, and for this study it was $\alpha=.90$. Some minor changes were made to the original questions. For instance, the original question "Looking back at the whole course, I am satisfied with our teamwork project" was replaced by "Looking back at the whole course, I am satisfied with our teamwork assignment."

Process satisfaction refers to the perceived satisfaction with general group functioning. Six items, each assessed on a 7-point Likert scale (1=Strongly Disagree, 7=Strongly Agree), were extracted from Strijbos, Martens, Jochems, and Broers (2007) where 64 students participated in a study involving computer-supported collaborative 
learning. The Cronbach's alpha for the perceived process satisfaction in the Strijbos et al. (2007) study was $\alpha=.71$, in the Canelon et al. (2011a) study it was $\alpha=.75$, for the Canelon et al. (2011b) study it was $\alpha=.76$, and for this study it was $\alpha=.80$. Some items were adapted to the online setting. For example, the question "I enjoyed talking with my group on the network" was changed to "I enjoyed interacting with the other team members through the online discussion tool."

Face loss is defined as the deterioration in one's social image (Chester and Bond, 2008). Based on Chester and Bond (2008) face loss constitutes a loss of social image, in consequence, people may react in order to restore or protect such status. Two items, each assessed on a 7-point Likert scale (1=Definitely Not, 7=Definitely), were extracted from Chester and Bond (2008) with an $\alpha=.71$ for the participants from the US, and $\alpha=.66$ for the participants from Hong Kong. Later, Hui and Bond (2009) used 7 items, each assessed on a 7-point Likert scale (1=Definitely Not, 7=Definitely), and they got an $\alpha=$ .84 for the participants from the US, and $\alpha=.82$ for the participants from Hong Kong. Based on these two studies, five items were extracted and adapted to the proposed study. In the Canelon et al. (2001a) study the estimated reliability was $\alpha=.89$, in Canelon et al. (2011b) it was $\alpha=.85$, and for this study it was $\alpha=.90$.

Team cohesion refers to perceived level of group cohesion. Ten items, each assessed on a 10-point Likert scale (1=Low, 10=High), were extracted from Strijbos et al. (2007). The Cronbach's alpha for team development in the Strijbos et al. (2007) study was $\alpha=.90$, in the Canelon et al. (2011a) study it was $\alpha=.95$, for the Canelon et al. (2011b) study it was $\alpha=.97$, and for this study it was $\alpha=.98$. The questions used in Canelon et al. (2011a) and Canelon et al. (2011b) are exactly the same as in the Strijbos study. 


\subsection{Research Questions and Hypotheses}

To answer the research questions and test the proposed model, the following hypotheses were posed:

H1: Facework behaviors will influence the conflict of the participants in the online discussion teams.

H1.1: Sex will moderate the influence between the facework behaviors and the conflict of the participants on the online discussion teams.

H2: Facework behaviors will influence the outcomes of the participants in the online discussion teams.

H2.1: Sex will moderate the influence between the facework behaviors and the outcomes of the participants on the online discussion teams.

H3: Conflicts will influence the performance of participants in the online discussion teams.

H3.1: Sex will moderate the relationship between the conflicts and the performance of the participants on the online discussion teams.

H4: Facework behaviors will moderate the influence between the conflicts and the outcomes of the online discussion teams.

H4.1: Sex will moderate the facework behaviors moderator effect on the influence between the conflicts and the outcomes of the online discussion teams. 


\section{Chapter 5 - Implementation}

\subsection{Participants}

The participants were 80 undergraduate students registered in a "Management Information Systems" course of a western U.S. university. IRB approval was obtained from the western US university and CGU. In addition, based on the fact that the experimental conditions in Canelon et al. (2011b) are the same as in this study, the data from the 69 participants from Canelon et al. (2011b) were used in this study as well for a total of 149 participants. The sample was composed of 84 males (57.04\%) and 65 females (42.96\%), with ages from 19 to 38 (mean $=22.97)$.

\subsection{Implementation Procedure}

Once the participants took the midterm test they were asked to read about the nature of their voluntary participation in the study. Participants had the opportunity to accept or refuse to participate in this study. Only $3 \%$ of the total sample population refused to participate.

The participants were randomly assigned to groups (4 participants per group ${ }^{1}$ ). During the next class, the participants received a tutorial about the concepts of face, facework, conflict, and facework behavior with examples of the facework behaviors extracted from the transcripts of previous iterations of this study (see Appendix C). Once every group received their tutorial, every participant was informed about all the steps necessary to perform the assignment (see Appendix A). After two weeks (duration of the assignment), all the participants completed an online survey (see Appendix B) on a voluntary basis. Only the surveys and posts from participants who wrote at least 10 posts

\footnotetext{
${ }^{1}$ There were 3 groups with 3 members each
} 
and completed the survey were considered for further analysis.

To choose the assignment topic to be discussed in this study, the participants in Canelon et al. (2011b) filled out a survey where they had to choose between 5 possible topics. The five pre-selected topics were determined a priori by the researcher. Every topic was evaluated with a 10-point Likert scale. The final topic chosen, which was the topic used in this study, was the one with the biggest variability. 


\section{Chapter 6 - Results}

The results of this study are presented in two sections. The first section shows the results from the quantitative analysis. The second section shows the results from the qualitative analysis.

\subsection{Quantitative Analysis Results}

The quantitative data collected from the survey were analyzed using SPSS 17.0. The quantitative results are discussed following the hypotheses established for this study.

\subsubsection{Hypothesis $\mathrm{H} 1$}

A stepwise regression analysis was performed to study the relationship between facework behaviors and conflict in the online discussion teams. Results from Table 19 show that the integrating facework category accounts for $3 \%$ of the variance in the conflict variable. The more that participants are involved in integrating behaviors, the less conflict there is.

A statistically significant regression equation did not emerge when the variable independent variable "sex" was included in the analysis. That is, sex did not play a moderating role in the relationship between facework behaviors and conflict in the online discussion teams.

Based on these findings, the hypothesis $\mathrm{H} 1$ is supported while hypothesis H1.1 is not supported. 
Table 19. Regression Analysis. Dependent Variable: Conflict

\begin{tabular}{|r|r|r|r|}
\hline \multicolumn{5}{|c|}{ Model Summary } \\
\hline \multicolumn{1}{|c|}{$\mathrm{R}$} & R Square & $\begin{array}{c}\text { Adjusted R } \\
\text { Square }\end{array}$ & $\begin{array}{c}\text { Std. Error of } \\
\text { the Estimate }\end{array}$ \\
\hline $.17^{\mathrm{a}}$ & .03 & .02 & .92 \\
\hline
\end{tabular}

a. Predictors: (Constant), Integrating

\begin{tabular}{|l|r|r|r|r|r|}
\multicolumn{1}{l|}{ ANOVA $^{\mathbf{b}}$} \\
$\begin{array}{l}\text { Sum of } \\
\text { Squares }\end{array}$ & $\mathrm{df}$ & Mean Square & F & Sig. \\
\hline Regression & 3.54 & 1 & 3.54 & 4.16 & $.04^{\mathrm{a}}$ \\
\hline Residual & 124.22 & 146 & .85 & & \\
\hline Total & 127.76 & 147 & & & \\
\hline
\end{tabular}

a. Predictors: (Constant), Integrating

b. Dependent Variable: Conflict

\begin{tabular}{|l|r|r|c|c|c|}
\hline \multirow{3}{*}{ Model } & \multicolumn{2}{|c|}{$\begin{array}{c}\text { Unstandardized } \\
\text { Coefficients }\end{array}$} & $\begin{array}{c}\text { Standardized } \\
\text { Coefficients }\end{array}$ & & \\
\cline { 2 - 5 } & \multicolumn{1}{|c|}{$\mathrm{B}$} & Std. Error & Beta & \multicolumn{1}{c|}{ t } & Sig. \\
\hline (Constant) & 3.36 & .59 & & 5.67 & .00 \\
\hline Integrating & -.35 & .17 & -.17 & -2.04 & .04 \\
\hline
\end{tabular}

a. Dependent Variable: Conflict

\subsubsection{Hypothesis $\mathrm{H} 2$}

Regression analyses were performed to study the relationship between facework behaviors and outcomes of the online discussion teams. In addition, regression analyses were also used to study the role that sex plays in that relationship. Results are in Tables 20 and 21. 
Table 20. Regression Analysis. Dependent Variable: Satisfaction

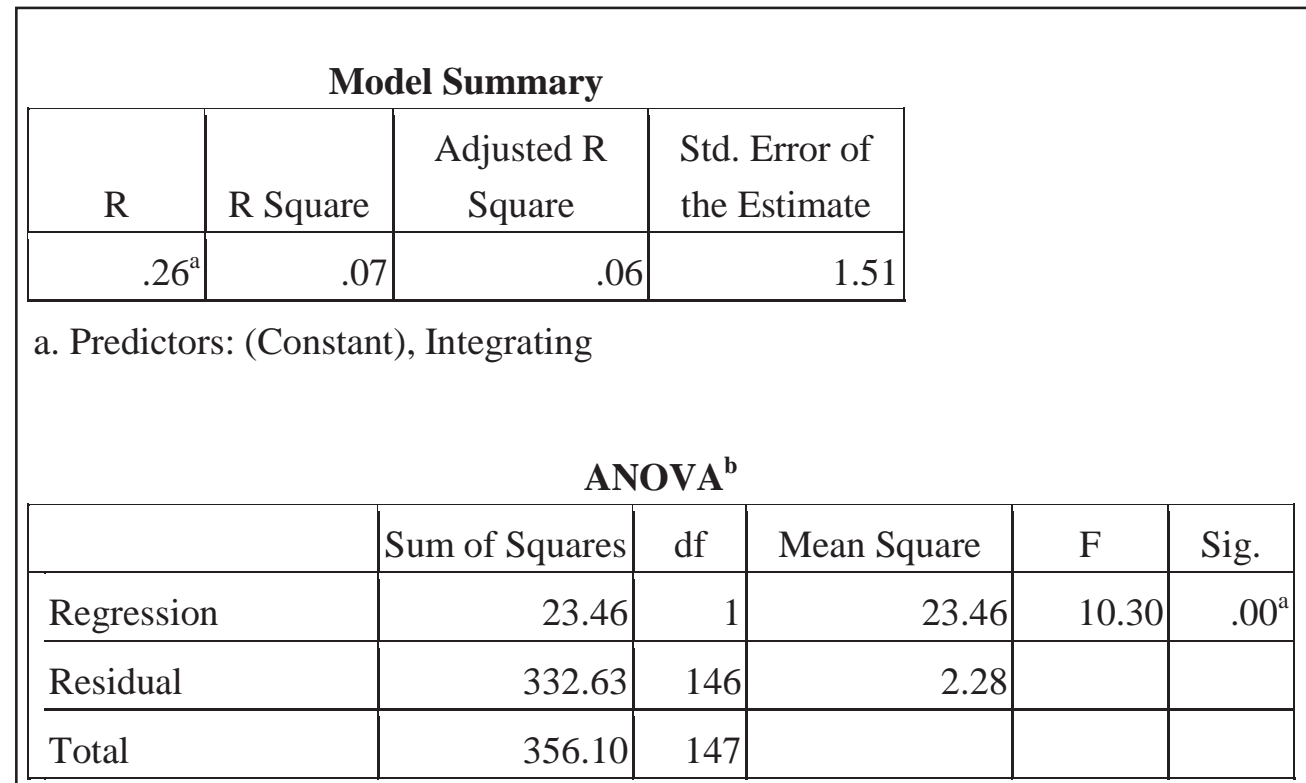

a. Predictors: (Constant), Integrating

b. Dependent Variable: Satisfaction

\begin{tabular}{|c|c|c|c|c|c|}
\hline \multicolumn{6}{|c|}{ Coefficients $^{\mathrm{a}}$} \\
\hline \multirow[b]{2}{*}{ Model } & \multicolumn{2}{|c|}{$\begin{array}{l}\text { Unstandardized } \\
\text { Coefficients }\end{array}$} & \multirow{2}{*}{$\begin{array}{c}\text { Standardized } \\
\text { Coefficients } \\
\text { Beta }\end{array}$} & \multirow[b]{2}{*}{$\mathrm{t}$} & \multirow[b]{2}{*}{ Sig. } \\
\hline & B & Std. Error & & & \\
\hline (Constant) & 4.75 & .97 & & 4.89 & .00 \\
\hline Integrating & .90 & .28 & .26 & 3.21 & .00 \\
\hline
\end{tabular}

a. Dependent Variable: Satisfaction

The integrating facework category accounts for

$7 \%$ of the variance in the satisfaction variable. The more that participants are involved in integrating facework behaviors, the more satisfied they are. 
Table 21. Regression Analysis. Dependent Variable: Face Loss

\begin{tabular}{|c|c|c|c|c|}
\hline \multicolumn{5}{|c|}{ Model Summary } \\
\hline Model & $\mathrm{R}$ & R Square & $\begin{array}{l}\text { Adjusted R } \\
\text { Square }\end{array}$ & $\begin{array}{l}\text { Std. Error of } \\
\text { the Estimate }\end{array}$ \\
\hline $\mid 1$ & $.28^{\mathrm{a}}$ & .08 & .06 & .88 \\
\hline
\end{tabular}

a. Predictors: (Constant), Dominating, Integrating

\begin{tabular}{||l|l|r|r|r|r|r|}
\multicolumn{7}{|c|}{ ANOVA $^{\mathbf{b}}$} \\
\multicolumn{1}{||l}{ Model } & Sum of Squares & \multicolumn{1}{c|}{ df } & Mean Square & F & \multicolumn{1}{c|}{ Sig. } \\
\hline \multirow{3}{*}{1} & Regression & 9.13 & 2 & 4.56 & 5.95 & $.00^{\mathrm{a}}$ \\
\cline { 2 - 8 } & Residual & 111.07 & 145 & .77 & & \\
\cline { 2 - 8 } & Total & 120.19 & 147 & & & \\
\hline
\end{tabular}

a. Predictors: (Constant), Dominating, Integrating

b. Dependent Variable: Face Loss

\section{Coefficients $^{\mathrm{a}}$}

\begin{tabular}{|c|c|c|c|c|c|c|}
\hline \multirow{2}{*}{\multicolumn{2}{|c|}{ |Model }} & \multicolumn{2}{|c|}{$\begin{array}{c}\text { Unstandardized } \\
\text { Coefficients }\end{array}$} & \multirow{2}{*}{$\begin{array}{c}\text { Standardized } \\
\text { Coefficients } \\
\text { Beta } \\
\end{array}$} & \multirow[b]{2}{*}{$\mathrm{t}$} & \multirow[b]{2}{*}{ Sig. } \\
\hline & & $\mathrm{B}$ & Std. Error & & & \\
\hline \multirow[t]{3}{*}{$\mid 1$} & (Constant) & 1.25 & .66 & & 1.91 & .06 \\
\hline & Dominating & .63 & .19 & .271 & 3.19 & .00 \\
\hline & Integrating & -.40 & .17 & -.197 & -2.32 & .02 \\
\hline
\end{tabular}

a. Dependent Variable: Face Loss

The dominating and integrating facework behaviors account for $8 \%$ of the variance in participants' face loss. The more that participants are involved in integrating facework behaviors, the lower their face loss, meanwhile the more dominating facework behaviors, the higher the face loss. Dominating facework behavior has a negative effect on face loss, while integrating facework behavior has a positive effect. 
To analyze the role that sex plays on the relationship between facework behaviors and outcomes of the online discussion teams, regression analyses were performed. See results in Tables 22, 23, and 24.

Table 22. Role of Sex on the relationship between Facework Behaviors Satisfaction

\begin{tabular}{||l|l|r|r|r|r|}
\hline \multicolumn{7}{|c|}{ Model Summary } \\
\hline & Model & \multicolumn{1}{c|}{$\mathrm{R}$} & \multicolumn{1}{c|}{ R Square } & $\begin{array}{c}\text { Adjusted R } \\
\text { Square }\end{array}$ & $\begin{array}{c}\text { Std. Error of the } \\
\text { Estimate }\end{array}$ \\
\hline Male & 1 & $.34^{\mathrm{a}}$ & .12 & .11 & 1.56 \\
\hline
\end{tabular}

a. Predictors: (Constant), Integrating

\begin{tabular}{|c|c|c|c|c|c|c|}
\hline \multicolumn{7}{|c|}{ ANOVA $^{\text {b }}$} \\
\hline & & Sum of Squares & $\mathrm{df}$ & $\begin{array}{l}\text { Mean } \\
\text { Square }\end{array}$ & $\mathrm{F}$ & Sig. \\
\hline \multirow[t]{3}{*}{ Male } & Regression & 26.11 & 1 & 26.11 & 10.71 & $.00^{\mathrm{a}}$ \\
\hline & Residual & 197.43 & 81 & 2.44 & & \\
\hline & Total & 223.54 & 82 & & & \\
\hline
\end{tabular}

a. Predictors: (Constant), Integrating

b. Dependent Variable: Satisfaction

\section{Coefficients $^{\mathrm{a}}$}

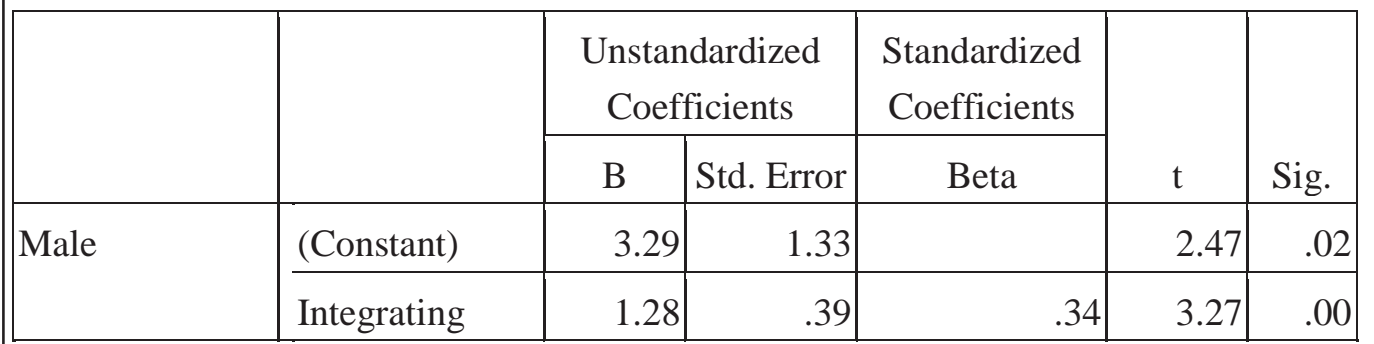

a. Dependent Variable: Satisfaction

Table 22 shows that for males, the integrating facework category accounts for $12 \%$ of the variance in outcome satisfaction. The more males are involved in integrating facework behaviors, the more satisfied they are. No facework category is related to females' satisfaction, nevertheless, a t-test comparing males and females shows that females $(\mathrm{M}=3.52, \mathrm{SD}=.44)$ are more involved in integrating facework category 
behaviors than males $(\mathrm{M}=3.35, \mathrm{SD}=.44)$. This difference is significant $t(147)=-2.21$, $p<0.05$. It represents a small-sized effect $r=0.18$. There are no significant differences between males and females in relation to the avoiding and dominating facework behaviors.

Table 23. Involvement in integrating facework behavior category between males and females

\begin{tabular}{|l|l|c|c|c|c|}
\hline \multicolumn{1}{|c|}{ Group } & Mean & SD & $t$ & $d f$ & $\begin{array}{c}P \text { value } \\
(2 \text {-tailed })\end{array}$ \\
\hline Males & 3.35 & .44 & -2.21 & 147 & $<.05$ \\
\hline Females & 3.52 & .44 & & \\
\hline
\end{tabular}

These results for males are aligned with the results in Canelon et al. (2011a) where the facework behaviors from the integrating category account for the majority of the facework behaviors related to the satisfaction of the participants of the online discussion teams.

Table 24 results show that the dominating facework category accounts for $7 \%$ of the variance for males' face loss; that is, the more that males are involved in dominating facework behaviors, the higher their face loss. No facework category is related to face loss for females.

Like in Canelon et al. (2011a) the dominating facework behaviors category is the only one related to face loss. Nevertheless, in Canelon et al. (2011a) the facework behavior aggression, which is one of the three facework behaviors of the category dominating, is related to female participants, while in this case it is related to male participants.

The results from Tables 20 and 21 show that facework behaviors are related to the outcomes of the online discussion teams. Results from Tables 22, 23, and 24 show that sex plays a role in the relationship between the facework behaviors and the outcomes of the online discussion teams. These results are aligned with the results from Canelon et 
al. (2011a). Based on these findings, hypothesis H2 is supported and H2.1 is partially supported.

Table 24. Role of Sex on the relationship between Facework Behaviors and Face Loss

\begin{tabular}{||r|r|r|r|r|}
\hline \multicolumn{7}{|c|}{ Model Summary } \\
\hline & $\mathrm{R}$ & \multicolumn{1}{|c|}{ R Square } & $\begin{array}{c}\text { Adjusted R } \\
\text { Square }\end{array}$ & $\begin{array}{l}\text { Std. Error of } \\
\text { the Estimate }\end{array}$ \\
\hline Male & $.26^{\mathrm{a}}$ & .07 & .06 & .84 \\
\hline
\end{tabular}

a. Predictors: (Constant), Dominating

\begin{tabular}{||l|l|r|r|r|r|r|}
\hline \multicolumn{1}{||}{} & \multicolumn{1}{c|}{$\begin{array}{c}\text { Sum of } \\
\text { Squares }\end{array}$} & $\mathrm{df}$ & $\begin{array}{c}\text { Mean } \\
\text { Square }\end{array}$ & \multicolumn{1}{c|}{$\mathrm{F}$} & Sig. \\
\hline Male & Regression & 4.07 & 1 & 4.07 & 5.76 & $.02^{\mathrm{a}}$ \\
\cline { 2 - 9 } & Residual & 57.15 & 81 & .71 & & \\
\hline & Total & 61.22 & 82 & & & \\
\hline
\end{tabular}

a. Predictors: (Constant), Dominating

b. Dependent Variable: Face Loss

\begin{tabular}{|c|c|c|c|c|c|c|}
\hline \multicolumn{7}{|c|}{ Coefficients $^{\mathrm{a}}$} \\
\hline & & \multicolumn{2}{|c|}{$\begin{array}{l}\text { Unstandardized } \\
\text { Coefficients }\end{array}$} & \multirow{2}{*}{$\begin{array}{c}\begin{array}{c}\text { Standardized } \\
\text { Coefficients }\end{array} \\
\text { Beta }\end{array}$} & \multirow[b]{2}{*}{$\mathrm{t}$} & \multirow[b]{2}{*}{ Sig. } \\
\hline & & B & Std. Error & & & \\
\hline \multirow[t]{2}{*}{ Male } & (Constant) & .19 & .59 & & .34 & .747 \\
\hline & Dominating & .50 & .21 & .26 & 2.40 & .02 \\
\hline
\end{tabular}

a. Dependent Variable: Face Loss

\subsubsection{Hypothesis H3}

The analysis of the relationship between conflict and the outcomes of the online discussion team was performed in two steps. First, regression analyses were performed to study the relationship between conflict and online discussion outcomes. Second, t-tests 
were calculated to examine the difference between groups under specific conditions. The regression analyses results are in Tables 25, 26, 27, and 29.

Table 25. Regression Analysis. Dependent Variable: Satisfaction - Both Sexes included

\begin{tabular}{|c|c|c|c|c|c|c|c|}
\hline \multicolumn{6}{|c|}{ Model Summary } & & \\
\hline Model & $\mathrm{R}$ & R Square & \multicolumn{2}{|c|}{$\begin{array}{l}\text { Adjusted R } \\
\text { Square }\end{array}$} & $\begin{array}{l}\text { Std. Error of } \\
\text { the Estimate }\end{array}$ & & \\
\hline 1 & $.35^{\mathrm{a}}$ & .12 & & .11 & 1.46 & & \\
\hline \multicolumn{8}{|c|}{ a. Predictors: (Constant), Conflict, Sex: (0: Male; 1: Female) } \\
\hline \multicolumn{8}{|c|}{ ANOVA $^{b}$} \\
\hline \multicolumn{2}{|l|}{ Model } & \multicolumn{2}{|c|}{ Sum of Squares } & $\mathrm{df}$ & Mean Square & F & Sig. \\
\hline \multirow[t]{3}{*}{1} & Regression & & 44.10 & 2 & 22.05 & 10.32 & $.000^{\mathrm{a}}$ \\
\hline & Residual & & 311.99 & 146 & 2.14 & & \\
\hline & Total & & 356.09 & 148 & & & \\
\hline
\end{tabular}

a. Predictors: (Constant), Conflict, Sex: (0: Male; 1: Female)

b. Dependent Variable: Satisfaction

\section{Coefficients $^{\mathrm{a}}$}

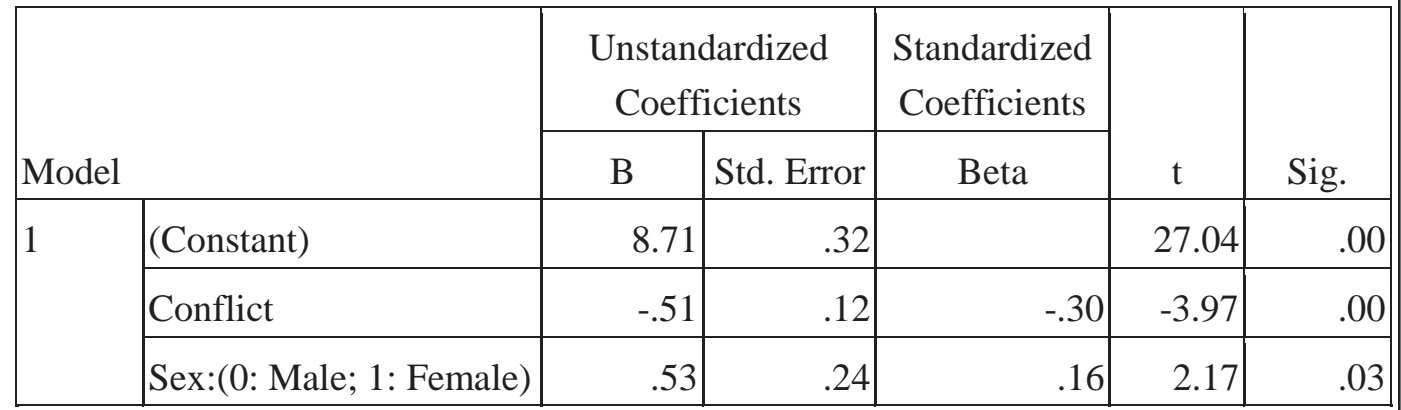

a. Dependent Variable: Satisfaction

Results from Table 25 show that conflict levels and sex of the participants account for $12 \%$ of the variance in the participants' satisfaction; that is, the more the conflict, the less the satisfaction, and females are more satisfied than males. 
Table 26. Regression Analysis. Dependent Variable: Satisfaction

\begin{tabular}{|l|r|r|r|r|}
\hline \multicolumn{7}{|c|}{ Model Summary } \\
\hline & $\mathrm{R}$ & R Square & $\begin{array}{c}\text { Adjusted R } \\
\text { Square }\end{array}$ & $\begin{array}{c}\text { Std. Error of } \\
\text { the Estimate }\end{array}$ \\
\hline Female & $.45^{\mathrm{a}}$ & .21 & .19 & 1.24 \\
\hline
\end{tabular}

a. Predictors: (Constant), Conflict

\begin{tabular}{|c|c|c|c|c|c|c|}
\hline \multicolumn{7}{|c|}{ ANOVA $^{\mathbf{b}}$} \\
\hline & & $\begin{array}{l}\text { Sum of } \\
\text { Squares }\end{array}$ & df & $\begin{array}{l}\text { Mean } \\
\text { Square }\end{array}$ & $\mathrm{F}$ & Sig. \\
\hline \multirow[t]{3}{*}{ Female } & Regression & 25.61 & 1 & 25.61 & 16.73 & $.00^{\mathrm{a}}$ \\
\hline & Residual & 96.48 & 63 & 1.53 & & \\
\hline & Total & 122.09 & 64 & & & \\
\hline
\end{tabular}

a. Predictors: (Constant), Conflict

b. Dependent Variable: Satisfaction

Coefficients $^{\mathrm{a}}$

\begin{tabular}{|c|c|c|c|c|c|c|}
\hline & & \multicolumn{2}{|c|}{$\begin{array}{c}\text { Unstandardized } \\
\text { Coefficients }\end{array}$} & \multirow{2}{*}{$\begin{array}{c}\text { Standardized } \\
\text { Coefficients } \\
\text { Beta } \\
\end{array}$} & \multirow[b]{2}{*}{$\tau$} & \multirow[b]{2}{*}{ Sig. } \\
\hline & & $\mathrm{B}$ & Std. Error & & & \\
\hline \multirow[t]{2}{*}{ Female } & (Constant) & 9.49 & .37 & & 25.90 & .000 \\
\hline & Conflict & -.63 & .15 & -.45 & -4.09 & .000 \\
\hline
\end{tabular}

a. Dependent Variable: Satisfaction

For females, conflict accounts for $21 \%$ of the variance in satisfaction. The more females are in conflict, the less satisfied they are. There are no statistically significant variables related to males' satisfaction. There is no statistically significant regression equation that relates the conflict variable with males' satisfaction.

Results from Table 25 show that there is a relationship between conflict and satisfaction. Meanwhile, the results from Table 26 points out that conflict influences females' satisfaction; that is, the more the conflict the less the satisfaction. Conflict is not related to males' satisfaction. 
A partial correlation between conflict and satisfaction, keeping face loss constant, found that for females, there is a significant relationship between conflict and satisfaction, $r=-.32, p<.05$. The relationship is not significant for males. This supports the results from Table 26 .

Table 27. Face Loss - Both Sexes included

\begin{tabular}{|l|r|r|r|r|}
\hline \multicolumn{7}{|c|}{ Model Summary } \\
\hline Model & \multicolumn{1}{|c|}{$\mathrm{R}$} & R Square & $\begin{array}{c}\text { Adjusted R } \\
\text { Square }\end{array}$ & $\begin{array}{c}\text { Std. Error of } \\
\text { the Estimate }\end{array}$ \\
\hline 1 & $.38^{\mathrm{a}}$ & .15 & .14 & .84 \\
\hline
\end{tabular}

a. Predictors: (Constant), Conflict

\begin{tabular}{|c|c|c|c|c|c|c|}
\hline \multicolumn{7}{|c|}{ ANOVA $^{b}$} \\
\hline \multicolumn{2}{|c|}{ Model } & Sum of Squares & df & $\begin{array}{l}\text { Mean } \\
\text { Square }\end{array}$ & $\mathrm{F}$ & Sig. \\
\hline \multirow[t]{3}{*}{1} & Regression & 17.88 & 1 & 17.88 & 25.60 & $.00^{\mathrm{a}}$ \\
\hline & Residual & 102.67 & 147 & .69 & & \\
\hline & Total & 120.56 & 148 & & & \\
\hline
\end{tabular}

a. Predictors: (Constant), Conflict

b. Dependent Variable: Face Loss

\begin{tabular}{|c|c|c|c|c|c|c|}
\hline \multicolumn{7}{|c|}{ Coefficients $^{\mathrm{a}}$} \\
\hline & & \multicolumn{2}{|c|}{$\begin{array}{c}\text { Unstandardized } \\
\text { Coefficients }\end{array}$} & $\begin{array}{c}\text { Standardized } \\
\text { Coefficients }\end{array}$ & \multirow[b]{2}{*}{$\mathrm{t}$} & \multirow[b]{2}{*}{ Sig. } \\
\hline \multicolumn{2}{|c|}{ Model } & B & Std. Error & Beta & & \\
\hline \multirow[t]{2}{*}{1} & (Constant) & .79 & .17 & & 4.58 & .00 \\
\hline & Conflict & .37 & .07 & .38 & 5.06 & .00 \\
\hline
\end{tabular}

a. Dependent Variable: Face Loss

From Table 27, the conflict levels account for $15 \%$ of the variance in the participants' face loss; that is, the more the conflict, the higher the participants' face loss. Based on Table 29, the conflict level accounts for $11 \%$ of the variance in males' face loss; 
that is, the more the conflict the higher males' face loss. For females, the conflict level accounts for $20 \%$ of the variance in their face loss; that is, the more the conflict, the higher the face loss. For both sexes, the more the conflict, the more the face loss.

A partial correlation between conflict and face loss, keeping constant satisfaction, shows that for males there is a significant relationship, $r=.30, p<.05$. For females, there is also a significant relationship, $r=.30, p<.05$. This is consistent with the results from Table 29.

In addition to regression analyses, t-tests were done to examine differences, under specific conditions such as variations on levels of conflict (low and high conflict) and sex (males and females), in the relationship between conflict and the online discussion outcomes. First the relationship with satisfaction is explained, and then the relationship with face loss.

Satisfaction

Males with conflict scores below the mean $(\mathrm{M}=2.16, \mathrm{SD}=.93)$ apparently experience more satisfaction $(\mathrm{M}=7.89, \mathrm{SD}=1.62$ ) than males with conflict scores above or equal to the mean $(\mathrm{M}=7.18, \mathrm{SD}=1.60)$, but this difference is not significant $t(82)=$ 1.97, $p>0.05$ (see Table 28). This t-test shows that there is not a significant difference between males with lower and higher levels of conflict. This result is aligned with the results from Table 26, where there is no regression equation for male participants.

Table 28. Satisfaction between males with higher and lower conflict levels

\begin{tabular}{|l|c|c|c|c|c|}
\hline \multicolumn{1}{|c|}{ Group } & Mean & SD & $t$ & $d f$ & $\begin{array}{c}P \text { value } \\
\text { (2-tailed) }\end{array}$ \\
\cline { 1 - 5 } Males with conflict level below the mean & 7.89 & 1.62 & \multirow{2}{*}{1.97} & 82 & $>.05$ \\
\cline { 1 - 5 } \\
$\begin{array}{l}\text { Males with conflict level above or equal } \\
\text { the mean }\end{array}$ & 7.18 & 1.60 & 1.97 & \\
\hline
\end{tabular}


Table 29. Regression Analysis. Dependent Variable: Face Loss

\begin{tabular}{|c|c|c|c|c|c|}
\hline \multicolumn{6}{|c|}{ Model Summary } \\
\hline & Model & $\mathrm{R}$ & R Square & $\begin{array}{l}\text { Adjusted R } \\
\text { Square }\end{array}$ & $\begin{array}{l}\text { Std. Error of the } \\
\text { Estimate }\end{array}$ \\
\hline Male & 1 & $.32^{\mathrm{a}}$ & .11 & .09 & .82 \\
\hline Female & 1 & $.45^{\mathrm{a}}$ & .20 & .19 & .86 \\
\hline
\end{tabular}

a. Predictors: (Constant), Conflict

\begin{tabular}{|c|c|c|c|c|c|c|c|}
\hline \multicolumn{8}{|c|}{ ANOVA $^{\text {b }}$} \\
\hline & \multicolumn{2}{|c|}{ Model } & $\begin{array}{l}\text { Sum of } \\
\text { Squares }\end{array}$ & df & $\begin{array}{l}\text { Mean } \\
\text { Square }\end{array}$ & $\mathrm{F}$ & Sig. \\
\hline \multirow[t]{3}{*}{ Male } & \multirow[t]{3}{*}{1} & Regression & 6.45 & 1 & 6.45 & 9.60 & $.00^{\mathrm{a}}$ \\
\hline & & Residual & 55.10 & 82 & .67 & & \\
\hline & & Total & 61.55 & 83 & & & \\
\hline \multirow[t]{3}{*}{ Female } & \multirow[t]{3}{*}{1} & Regression & 11.88 & 1 & 11.88 & 15.92 & $.00^{\mathrm{a}}$ \\
\hline & & Residual & 46.99 & 63 & .75 & & \\
\hline & & Total & 58.87 & 64 & & & \\
\hline
\end{tabular}

a. Predictors: (Constant), Conflict

b. Dependent Variable: Face Loss

\begin{tabular}{|c|c|c|c|c|c|c|c|}
\hline \multicolumn{8}{|c|}{ Coefficients $^{\mathrm{a}}$} \\
\hline & & & \multicolumn{2}{|c|}{$\begin{array}{l}\text { Unstandardized } \\
\text { Coefficients }\end{array}$} & \multirow{2}{*}{$\begin{array}{c}\text { Standardized } \\
\text { Coefficients } \\
\text { Beta }\end{array}$} & \multirow[b]{2}{*}{$\mathrm{t}$} & \multirow[b]{2}{*}{ Sig. } \\
\hline & \multicolumn{2}{|c|}{ Model } & B & Std. Error & & & \\
\hline \multirow[t]{2}{*}{ Male } & \multirow[t]{2}{*}{1} & (Constant) & .89 & .24 & & 3.72 & .00 \\
\hline & & Conflict & .31 & .10 & .32 & 3.09 & .00 \\
\hline \multirow[t]{2}{*}{ Female } & \multirow[t]{2}{*}{1} & (Constant) & .71 & .26 & & 2.78 & .00 \\
\hline & & Conflict & .43 & .11 & .45 & 3.99 & .00 \\
\hline
\end{tabular}

a. Dependent Variable: Face Loss

Females with conflict scores below the mean $(\mathrm{M}=2.16$, $\mathrm{SD}=.93)$ experience more satisfaction $(\mathrm{M}=8.57, \mathrm{SD}=1.12)$ than females with conflict scores above or equal the mean $(\mathrm{M}=7.33, \mathrm{SD}=1.47)$. This difference is significant $t(63)=3.83, p<0.001$. It represents a medium-sized effect $r=0.43$ (see Table 30). This t-test shows that females 
with lower conflict level experience more satisfaction than females with higher levels of conflict.

Table 30. Satisfaction between females with higher and lower conflict levels

\begin{tabular}{|c|c|c|c|c|c|}
\hline Group & Mean & SD & $t$ & $d f$ & $\begin{array}{l}P \text { value } \\
\text { (2-tailed) }\end{array}$ \\
\hline Females with conflict level below the mean & 8.57 & 1.12 & \multirow[b]{2}{*}{3.83} & \multirow[b]{2}{*}{63} & \multirow[b]{2}{*}{$<.001$} \\
\hline $\begin{array}{l}\text { Females with conflict level above or equal } \\
\text { the mean }\end{array}$ & 7.33 & 1.47 & & & \\
\hline
\end{tabular}

Participants with conflict scores below the mean $(\mathrm{M}=2.16, \mathrm{SD}=.93)$ experience more satisfaction $(\mathrm{M}=8.20, \mathrm{SD}=1.45)$ than participants with conflict scores above or equal the mean $(\mathrm{M}=7.24, \mathrm{SD}=1.53)$. This difference is significant $t(147)=3.84, p<$ 0.001. It represents a medium-sized effect $r=0.30$ (see Table 31). This t-test shows that participants with lower conflict levels experience more satisfaction than participants with higher levels of conflict.

Table 31. Satisfaction between participants with higher and lower conflict levels

\begin{tabular}{|l|c|c|c|c|c|}
\hline \multicolumn{1}{|c|}{ Group } & Mean & SD & $t$ & $d f$ & $\begin{array}{c}P \text { value } \\
(2 \text {-tailed) }\end{array}$ \\
\hline $\begin{array}{l}\text { Participants with conflict level below the } \\
\text { mean }\end{array}$ & 8.20 & 1.45 & \multirow{2}{*}{3.84} & 147 & $<.001$ \\
\cline { 1 - 1 } $\begin{array}{l}\text { Participants with conflict level above or } \\
\text { equal the mean }\end{array}$ & 7.24 & 1.53 & & \\
\hline
\end{tabular}

Males with conflict scores below the mean $(\mathrm{M}=2.16$, $\mathrm{SD}=.93)$ experience lower satisfaction $(\mathrm{M}=7.89, \mathrm{SD}=1.62)$ than females with conflict scores below the mean $(\mathrm{M}=8.58, \mathrm{SD}=1.12)$. This difference is significant $t(86.96)=-2.39, p<0.05$. It represents a small-sized effect $r=0.25$ (see Table 32). This t-test shows that females with lower conflict levels experience more satisfaction than males with lower levels of conflict.

Table 32. Satisfaction between males and females with lower levels of conflict

\begin{tabular}{|l|c|c|c|c|c|}
\hline \multicolumn{1}{|c|}{ Group } & Mean & SD & $t$ & $d f$ & $\begin{array}{c}P \text { value } \\
(2 \text {-tailed })\end{array}$ \\
\hline Males with conflict level below the mean & 7.89 & 1.62 & \multirow{2}{*}{-2.39} & 86.96 & $<.05$ \\
\hline Females with conflict level below the mean & 8.58 & 1.12 & & \\
\hline
\end{tabular}


Males with conflict scores above the mean $(\mathrm{M}=2.16$, $\mathrm{SD}=.93)$ experience lower satisfaction $(\mathrm{M}=7.18, \mathrm{SD}=1.60)$ than females with conflict scores above or equal the mean $(\mathrm{M}=7.33, \mathrm{SD}=1.47)$, but this difference is not significant $t(55)=-.36, p>$ 0.05 (see Table 33). This t-test shows that there is not a significant difference between males and females with conflict level above the mean.

Table 33. Satisfaction between males and females with higher levels of conflict

\begin{tabular}{|l|l|c|c|c|c|}
\hline \multicolumn{1}{|c|}{ Group } & Mean & SD & $t$ & $d f$ & $\begin{array}{c}P \text { value } \\
(2 \text {-tailed })\end{array}$ \\
\hline Males with conflict level above the mean & 7.18 & 1.60 & \multirow{2}{*}{-.36} & 55 & $>.05$ \\
\hline Females with conflict level above the mean & 7.33 & 1.47 & 56 & \\
\hline
\end{tabular}

Males experience lower satisfaction $(\mathrm{M}=7.6, \mathrm{SD}=1.64)$ than females $(\mathrm{M}=$ 8.13, $\mathrm{SD}=1.38$ ). This difference is significant $t(147)=-2.10, p<0.05$. It represents a small-sized effect $r=0.17$ (see Table 34). This t-test shows that females experience more satisfaction than males.

Table 34. Satisfaction between males and females

\begin{tabular}{|l|l|c|c|c|c|}
\hline \multicolumn{1}{|c|}{ Group } & Mean & SD & $t$ & $d f$ & $\begin{array}{c}P \text { value } \\
(2 \text {-tailed })\end{array}$ \\
\hline Males & 7.60 & 1.64 & -2.10 & 147 & $<.05$ \\
\hline Females & 8.13 & 1.38 & & \\
\hline
\end{tabular}

The previous t-tests mean:

1. Participants (overall and females) with higher levels of conflict have lower satisfaction than participants with lower levels of conflict; that is, with more conflict there is less satisfaction.

2. Females have more satisfaction than males, nevertheless there is a conflictlevel interaction, because the effect is not present at higher levels of conflict. 
Face Loss

Males with conflict scores below the mean $(\mathrm{M}=2.16, \mathrm{SD}=.93)$ experience lower face loss $(\mathrm{M}=1.35$, $\mathrm{SD}=.63)$ than males with conflict scores above or equal the mean $(\mathrm{M}=1.91, \mathrm{SD}=1.03)$. This difference is significant $t(49.53)=-2.83, p<0.05$. It represents a medium-sized effect $r=0.37$ (see Table 35). This t-test shows that males with lower conflict levels experience less face loss than males with higher levels of conflict.

Table 35. Face Loss between males with higher and lower conflict levels

\begin{tabular}{|l|c|c|c|c|c|}
\hline \multicolumn{1}{|c|}{ Group } & Mean & SD & $t$ & $d f$ & $\begin{array}{c}P \text { value } \\
(2 \text {-tailed })\end{array}$ \\
\cline { 1 - 3 } Males with conflict level below the mean & 1.35 & 0.63 & \multirow{2}{*}{-2.83} & 49.53 & $<.05$ \\
\cline { 1 - 5 } \\
$\begin{array}{l}\text { Males with conflict level above or equal } \\
\text { the mean }\end{array}$ & 1.91 & 1.03 & -2.83 & \\
\hline
\end{tabular}

Females with conflict scores below the mean $(\mathrm{M}=2.16$, $\mathrm{SD}=.93)$ experience lower face loss $(\mathrm{M}=1.32$, $\mathrm{SD}=.75)$ than females with conflict scores above or equal the mean $(\mathrm{M}=2.20, \mathrm{SD}=1.04)$. This difference is significant $t(34.66)=-3.58 p<0.001$. It represents a large-sized effect $r=0.52$ (see Table 36). This t-test shows that females with lower conflict levels experience less face loss than females with higher levels of conflict.

Table 36. Face Loss between females with higher and lower conflict levels

\begin{tabular}{|c|c|c|c|c|c|}
\hline Group & Mean & SD & $t$ & $d f$ & $\begin{array}{l}P \text { value } \\
\text { (2-tailed) }\end{array}$ \\
\hline Females with conflict level below the mean & 1.32 & 0.75 & \multirow[b]{2}{*}{-3.58} & \multirow[b]{2}{*}{34.66} & \multirow[b]{2}{*}{$<.001$} \\
\hline $\begin{array}{l}\text { Females with conflict level above or equal } \\
\text { the mean }\end{array}$ & 2.20 & 1.04 & & & \\
\hline
\end{tabular}

Participants with conflict scores below the mean $(\mathrm{M}=2.16, \mathrm{SD}=.93)$ experience lower face loss $(\mathrm{M}=1.38, \mathrm{SD}=.68)$ than participants with conflict scores above or equal the mean $(\mathrm{M}=2.03, \mathrm{SD}=1.04)$. This difference is significant $t(86.09)=-4.47$, $p<0.001$. It represents a medium-sized effect $r=0.43$ (see Table 37). This t-test shows that participants with lower conflict levels experience less face loss than participants with higher levels of conflict. 
Table 37. Face Loss between participants with higher and lower conflict levels

\begin{tabular}{|l|c|c|c|c|c|}
\hline \multicolumn{1}{|c|}{ Group } & Mean & SD & $t$ & $d f$ & $\begin{array}{c}P \text { value } \\
(2 \text {-tailed })\end{array}$ \\
\hline $\begin{array}{l}\text { Participants with conflict level below the } \\
\text { mean }\end{array}$ & 1.38 & 0.68 & \multirow{2}{*}{-4.47} & 86.09 & $<.001$ \\
\cline { 1 - 3 } $\begin{array}{l}\text { Participants with conflict level above or } \\
\text { equal the mean }\end{array}$ & 2.03 & 1.04 & & \\
\hline
\end{tabular}

Males with conflict scores below the mean $(\mathrm{M}=2.16, \mathrm{SD}=.93)$ experience higher face loss $(\mathrm{M}=1.35, \mathrm{SD}=.63)$ than females with conflict scores below the mean $(\mathrm{M}=1.32, \mathrm{SD}=.75)$, but this difference is not significant $t(90)=.17, p>0.05$ (see Table 38). This t-test shows that there is not a significant difference between males and females with conflict levels below the mean.

Table 38. Face Loss between males and females with lower levels of conflict

\begin{tabular}{|l|c|c|c|c|c|}
\hline \multicolumn{1}{|c|}{ Group } & Mean & SD & $t$ & $d f$ & $\begin{array}{c}P \text { value } \\
(2 \text {-tailed })\end{array}$ \\
\hline Males with conflict level below the mean & 1.35 & 0.63 & \multirow{2}{*}{.17} & 90 & $>.05$ \\
\hline Females with conflict level below the mean & 1.32 & 0.75 & .17 & \\
\hline
\end{tabular}

Males with conflict scores above the mean $(\mathrm{M}=2.16$, $\mathrm{SD}=.93)$ experience lower face loss $(\mathrm{M}=1.91, \mathrm{SD}=1.03)$ than females with conflict scores above or equal the mean $(M=2.20, S D=1.04)$, but this difference is not significant $t(55)=-1.05$, $p>0.05$ (see Table 39). This t-test shows that there is not a significant difference between males and females with conflict levels above the mean.

Table 39. Face Loss between males and females with higher levels of conflict

\begin{tabular}{|l|c|c|c|c|c|}
\hline \multicolumn{1}{|c|}{ Group } & Mean & SD & $t$ & $d f$ & $\begin{array}{c}P \text { value } \\
\text { (2-tailed) }\end{array}$ \\
\hline Males with conflict level above the mean & 1.91 & 1.03 & \multirow{2}{*}{-1.05} & 55 & $>$ \\
\cline { 1 - 5 } Females with conflict level above the mean & 2.20 & 1.04 & & \\
\hline
\end{tabular}

Males experience lower face loss $(M=1.57, \mathrm{SD}=.86)$ than females $(\mathrm{M}=1.63$, $\mathrm{SD}=.95$ ), but this difference is not significant $t(147)=-.41, p<0.05$ (see Table 40). This t-test shows that there is not a significant difference between males and females in terms of face loss. 
Table 40. Face Loss between males and females

\begin{tabular}{|l|l|c|c|c|c|}
\hline \multicolumn{1}{|c|}{ Group } & Mean & SD & $t$ & $d f$ & $\begin{array}{c}P \text { value } \\
\text { (2-tailed) }\end{array}$ \\
\hline Males & 1.57 & 0.86 & -0.41 & 147 & $<.05$ \\
\hline Females & 1.63 & 0.95 & -0.41 & \\
\hline
\end{tabular}

The previous t-tests mean:

1. Participants (males and females) with conflict levels above the mean, have more face loss than participants with conflict levels below the mean; that is, the more the conflict, the more the face loss.

2. Sex does not influence the relationship between conflict and face loss.

Based on the results from Tables 25, 26, 27, 28 and 29, hypotheses H3 and H3.1 are partially supported.

\subsubsection{Hypothesis H4}

Stepwise multiple regression analyses were used to examine the relations between conflicts and the outcomes of the online discussion teams (satisfaction and face loss) and the interaction effect of the facework behavior categories (dominating, avoiding, and integrating) on online discussion outcomes. For assessing the moderator effect, three cross product variables were calculated: conflict $\mathrm{X}$ avoiding, conflict $\mathrm{X}$ integrating, and conflict $\mathrm{X}$ dominating. Before any calculation, and to reduce the multicollinearity effects, these variables were centered according to the procedure described in Field (2009). The results are shown in Tables 41, 42, 43, and 44.

Results from Table 41 show that for males and females, the conflict levels and the integrating facework behaviors category account for $16 \%$ of the variance in satisfaction; that is, the lower the conflict levels and the higher the involvement in integrating facework behaviors, the higher the participants' satisfaction. In addition, females are more satisfied than males. 
Table 41. Regression Analysis. Moderator Effect. Dependent Variable: Satisfaction Both Sexes Included

\begin{tabular}{|r|r|c|c|}
\hline \multicolumn{5}{|c|}{ Model Summary } \\
\hline & & $\begin{array}{c}\text { Adjusted R } \\
\text { Square }\end{array}$ & $\begin{array}{c}\text { Std. Error of the } \\
\text { Estimate }\end{array}$ \\
\hline R & R Square & .14 & 1.44 \\
\hline .39 & .16 & a &
\end{tabular}

a. Predictors: (Constant), Sex:(0: Male; 1: Female), Conflict, Integrating

\begin{tabular}{|l|r|r|r|r|r|}
\hline \multicolumn{1}{|l|}{ ANOVA $^{\mathbf{b}}$} \\
& Sum of Squares & \multicolumn{1}{c|}{ df } & \multicolumn{1}{c|}{$\begin{array}{c}\text { Mean } \\
\text { Square }\end{array}$} & \multicolumn{1}{c|}{ F } & \multicolumn{1}{c|}{ Sig. } \\
\hline Regression & 55.89 & 3 & 18.633 & 8.93 & $.00^{\mathrm{a}}$ \\
\hline Residual & 300.19 & 144 & 2.085 & & \\
\hline Total & 356.09 & 147 & & & \\
\hline
\end{tabular}

a. Predictors: (Constant), Sex:(0: Male; 1: Female), Conflict, Integrating

d. Dependent Variable: Satisfaction

\begin{tabular}{|l|r|r|r|r|r||}
\hline \multirow{1}{*}{} & \multicolumn{2}{|c|}{$\begin{array}{c}\text { Coefficients } \\
\text { Unstandardized } \\
\text { Coefficients }\end{array}$} & $\begin{array}{c}\text { Standardized } \\
\text { Coefficients }\end{array}$ & & \\
\cline { 2 - 7 } & \multicolumn{1}{|c|}{$\mathrm{B}$} & $\begin{array}{c}\text { Std. } \\
\text { Error }\end{array}$ & \multicolumn{1}{c|}{ Beta } & \multicolumn{1}{c|}{$\mathrm{t}$} & \multicolumn{1}{c|}{ Sig. } \\
\hline (Constant) & 6.39 & 1.03 & & 6.23 & .00 \\
\hline Sex:(0: Male; 1: Female) & .42 & .24 & .136 & 1.75 & .08 \\
\hline Conflict & -.46 & .13 & -.277 & -3.56 & .00 \\
\hline Integrating & .66 & .27 & .187 & 2.37 & .02 \\
\hline
\end{tabular}

a. Dependent Variable: Satisfaction 
Table 42. Regression Analysis. Moderator Effect. Dependent Variable: Face Loss Both Sexes Included

\begin{tabular}{|l|r|r|r|r|}
\hline \multicolumn{7}{|c|}{ Model Summary } \\
\hline Model & $\mathrm{R}$ & R Square & $\begin{array}{c}\text { Adjusted R } \\
\text { Square }\end{array}$ & $\begin{array}{c}\text { Std. Error of } \\
\text { the Estimate }\end{array}$ \\
\hline 1 & $.42^{\mathrm{a}}$ & .18 & .17 & .83 \\
\hline
\end{tabular}

a. Predictors: (Constant), Conflict, Dominating

\begin{tabular}{|l} 
Model \\
\begin{tabular}{|l|l|r|r|r|r|r|}
\hline \multicolumn{2}{|l}{} & & & Mean & & \\
\hline 1 & Sum of Squares & df & Square & F & Sig. \\
\cline { 2 - 8 } & Regression & 21.42 & 2 & 10.71 & 15.72 & $.00^{\mathrm{a}}$ \\
\cline { 2 - 8 } & Residual & 98.78 & 145 & .68 & & \\
\cline { 2 - 8 } & Total & 120.19 & 147 & & & \\
\hline
\end{tabular}
\end{tabular}

a. Predictors: (Constant), Conflict, Dominating

b. Dependent Variable: Face Loss

\section{Coefficients $^{\mathrm{a}}$}

\begin{tabular}{|c|c|c|c|c|c|c|}
\hline & & $\begin{array}{r}\text { Unstand } \\
\text { Coeffi }\end{array}$ & $\begin{array}{l}\text { lardized } \\
\text { icients }\end{array}$ & $\begin{array}{c}\text { Standardized } \\
\text { Coefficients }\end{array}$ & & \\
\hline & & $\mathrm{B}$ & Std. Error & Beta & $\mathrm{t}$ & Sig. \\
\hline 1 & (Constant) & -.29 & .50 & & -.58 & .56 \\
\hline & Conflict & .36 & .07 & .37 & 4.91 & .00 \\
\hline & Dominating & .41 & .18 & .18 & 2.33 & .02 \\
\hline
\end{tabular}

a. Dependent Variable: Face Loss

Results from Table 42 show that for males and females the conflict levels and the dominating facework behaviors category account for $18 \%$ of the variance in satisfaction; that is, the more the conflict and the more the involvement in dominating facework behaviors, the higher the participants' face loss. 
Table 43. Regression Analysis. Moderator Effect. Dependent Variable: Satisfaction

\begin{tabular}{||l|l|r|r|r|r|}
\hline \multicolumn{7}{|c|}{ Model Summary } \\
\hline & Model & \multicolumn{1}{c|}{ R } & R Square & $\begin{array}{c}\text { Adjusted R } \\
\text { Square }\end{array}$ & $\begin{array}{c}\text { Std. Error of the } \\
\text { Estimate }\end{array}$ \\
\hline Male & 1 & $.34^{\mathrm{a}}$ & .12 & .11 & 1.56 \\
\hline Female & 1 & $.54^{\mathrm{b}}$ & .29 & .27 & 1.18 \\
\hline
\end{tabular}

a. Predictors: (Constant), Integrating

b. Predictors: (Constant), Conflict, ConflictXAvoiding

\begin{tabular}{|c|c|c|c|c|c|c|c|}
\hline \multicolumn{8}{|c|}{ ANOVA $^{c}$} \\
\hline & \multicolumn{2}{|c|}{ Model } & $\begin{array}{l}\text { Sum of } \\
\text { Squares }\end{array}$ & $\mathrm{df}$ & $\begin{array}{l}\text { Mean } \\
\text { Square }\end{array}$ & F & Sig. \\
\hline \multirow[t]{3}{*}{ Male } & \multirow[t]{3}{*}{1} & Regression & 26.11 & 1 & 26.11 & 10.71 & $.00^{\mathrm{a}}$ \\
\hline & & Residual & 197.43 & 81 & 2.44 & & \\
\hline & & Total & 223.54 & 82 & & & \\
\hline \multirow[t]{3}{*}{ Female } & \multirow[t]{3}{*}{1} & Regression & 35.51 & 2 & 17.76 & 12.72 & $.00^{\mathrm{b}}$ \\
\hline & & Residual & 86.58 & 62 & 1.40 & & \\
\hline & & Total & 122.09 & 64 & & & \\
\hline
\end{tabular}

a. Predictors: (Constant), Integrating

b. Predictors: (Constant), Conflict, ConflictXAvoiding

c. Dependent Variable: Satisfaction

\begin{tabular}{|c|c|c|c|c|c|c|c|}
\hline \multicolumn{8}{|c|}{ Coefficients $^{\mathrm{a}}$} \\
\hline & & & \multicolumn{2}{|c|}{$\begin{array}{c}\text { Unstandardized } \\
\text { Coefficients }\end{array}$} & \multirow{2}{*}{$\begin{array}{c}\begin{array}{c}\text { Standardized } \\
\text { Coefficients }\end{array} \\
\text { Beta }\end{array}$} & \multirow[b]{2}{*}{$\mathrm{t}$} & \multirow[b]{2}{*}{ Sig. } \\
\hline & \multicolumn{2}{|c|}{ Model } & B & Std. Error & & & \\
\hline \multirow[t]{2}{*}{ Male } & \multirow[t]{2}{*}{1} & (Constant) & 3.29 & 1.33 & & 2.47 & .02 \\
\hline & & Integrating & 1.28 & .39 & .34 & 3.27 & .00 \\
\hline \multirow[t]{3}{*}{ Female } & \multirow[t]{3}{*}{1} & (Constant) & 9.38 & .35 & & 26.61 & .00 \\
\hline & & Conflict & -.61 & .15 & -.44 & -4.10 & .00 \\
\hline & & $\begin{array}{l}\text { ConflictX } \\
\text { Avoiding }\end{array}$ & -.67 & .25 & -.29 & -2.66 & .01 \\
\hline
\end{tabular}

a. Dependent Variable: Satisfaction 
Table 44. Regression Analysis. Moderator Effect. Dependent Variable: Face Loss

\begin{tabular}{|c|c|c|c|c|c|c|c|}
\hline \multicolumn{8}{|c|}{ Model Summary } \\
\hline & Model & $\mathrm{R}$ & R Square & \multicolumn{2}{|c|}{$\begin{array}{l}\text { Adjusted R } \\
\text { Square }\end{array}$} & \multicolumn{2}{|c|}{$\begin{array}{l}\text { Std. Error of the } \\
\text { Estimate }\end{array}$} \\
\hline Male & 1 & $.46^{\mathrm{a}}$ & .21 & \multicolumn{2}{|r|}{.17} & \multicolumn{2}{|r|}{.78} \\
\hline Female & 1 & $.50^{\mathrm{b}}$ & .25 & \multicolumn{2}{|r|}{.22} & \multicolumn{2}{|r|}{.86} \\
\hline \multicolumn{8}{|c|}{$\begin{array}{l}\text { a. Predictors: (Constant), Conflict, Dominating, ConflictXIntegrating } \\
\text { b. Predictors: (Constant), Conflict, ConflictXAvoiding }\end{array}$} \\
\hline \multicolumn{8}{|c|}{ ANOVA $^{\text {b }}$} \\
\hline & \multicolumn{2}{|l|}{ Model } & $\begin{array}{l}\text { Sum of } \\
\text { Squares }\end{array}$ & df & $\begin{array}{l}\text { Mean } \\
\text { Square }\end{array}$ & $\mathrm{F}$ & Sig. \\
\hline \multirow[t]{3}{*}{ Male } & \multirow[t]{3}{*}{1} & Regression & 12.68 & 3 & 4.23 & 6.88 & $.00^{\mathrm{a}}$ \\
\hline & & Residual & 48.54 & 79 & .614 & & \\
\hline & & Total & 61.22 & 82 & & & \\
\hline \multirow[t]{3}{*}{ Female } & \multirow[t]{3}{*}{1} & Regression & 14.64 & 2 & 7.32 & 10.26 & $.00^{\mathrm{b}}$ \\
\hline & & Residual & 44.23 & 62 & .71 & & \\
\hline & & Total & 58.87 & 64 & & & \\
\hline
\end{tabular}

a. Predictors: (Constant), Conflict, Dominating, ConflictXIntegrating

b. Dependent Variable: Face Loss

\section{Coefficients $^{\mathrm{a}}$}

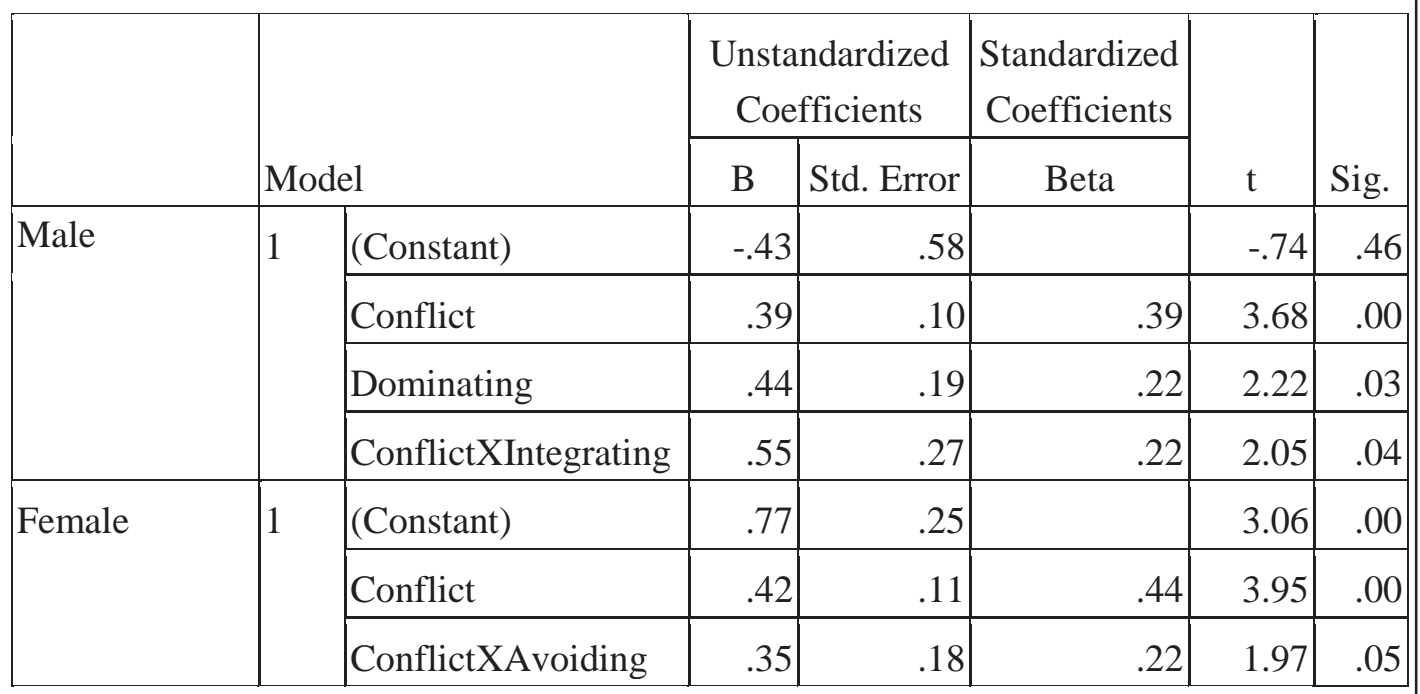

a. Dependent Variable: Face Loss 
Tables 43 and 44 show that for males, the integrating facework behaviors account for $12 \%$ of the variance in satisfaction. For females, two variables predict satisfaction, conflict and the interaction term conflict $\mathrm{X}$ avoiding. The more conflict within a team, the lower the females' satisfaction. The interaction term conflict $\mathrm{X}$ avoiding has a negative value; that is, females adopting higher levels of the avoiding facework behaviors category in high conflict situations have lower levels of satisfaction.

Figure 5 shows the effect of the level of the avoiding facework behaviors category on the relationship between conflict and satisfaction for females. Females adopting high levels of facework behaviors related to the avoiding facework behaviors category in high conflict situations have lower satisfaction, while females adopting lower levels of the facework behaviors from the avoiding facework behaviors category in high conflict situations have higher satisfaction.

Figure 5 - Interaction effect of level of the avoiding facework category on the relationship between conflict level and satisfaction for females

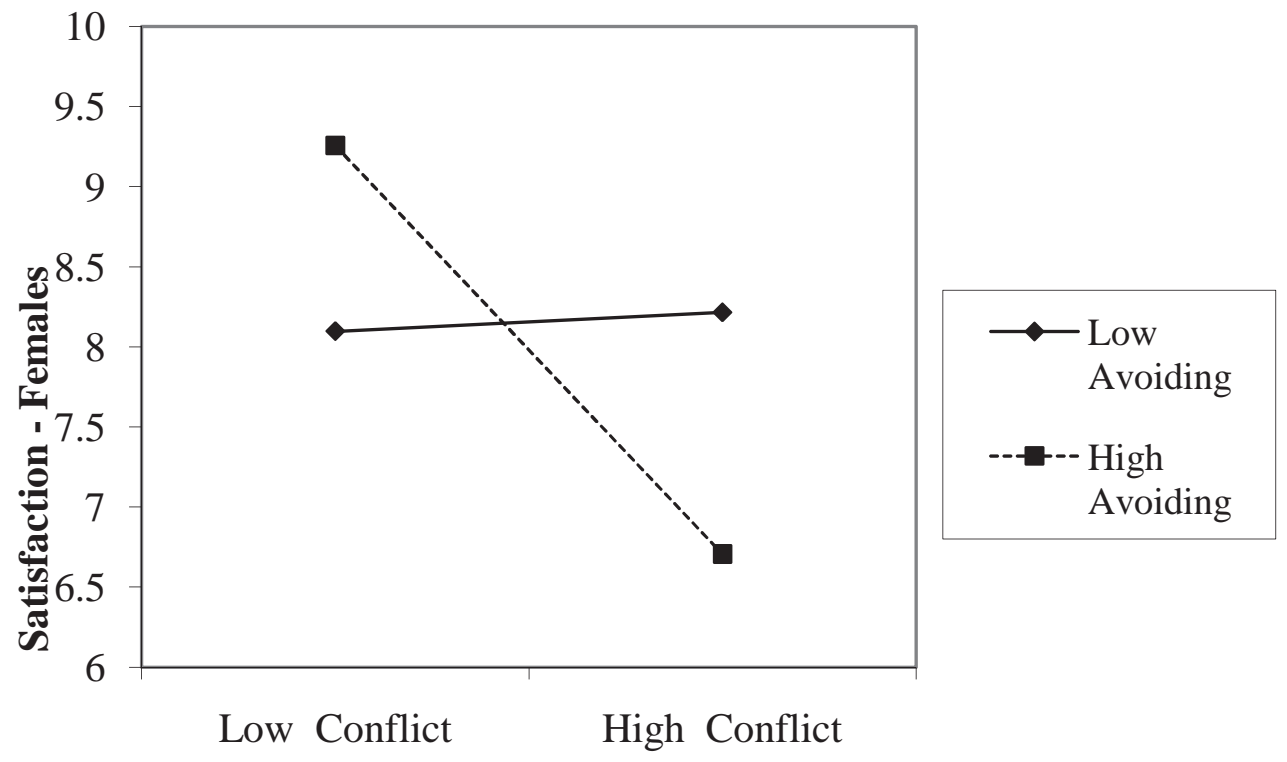

Three variables predict males' face loss, namely conflict, the integrating facework behaviors category, and the interaction term conflict $\mathrm{X}$ integrating, which 
account for $21 \%$ of the variance of face loss for males. The more the conflict in a team, the higher males' face loss. The more males engage in facework behaviors from the integrating facework category, the higher males' face loss. The interaction term conflict $\mathrm{X}$ integrating facework has a positive value; that is, males adopting higher levels of the integrating facework behaviors category in high conflict situations have higher levels of face loss.

Figure 6 shows the effect of the level of the integrating facework category on the relationship between conflict and face loss for males. Males adopting high levels of facework behaviors related to the integrating facework behaviors category in high conflict situations have higher face loss, while males adopting lower levels of the facework behaviors from the integrating facework behaviors category in high conflict situations have lower face loss.

Figure 6 - Interaction effect of level of the integrating facework category on the relationship between conflict level and face loss for males

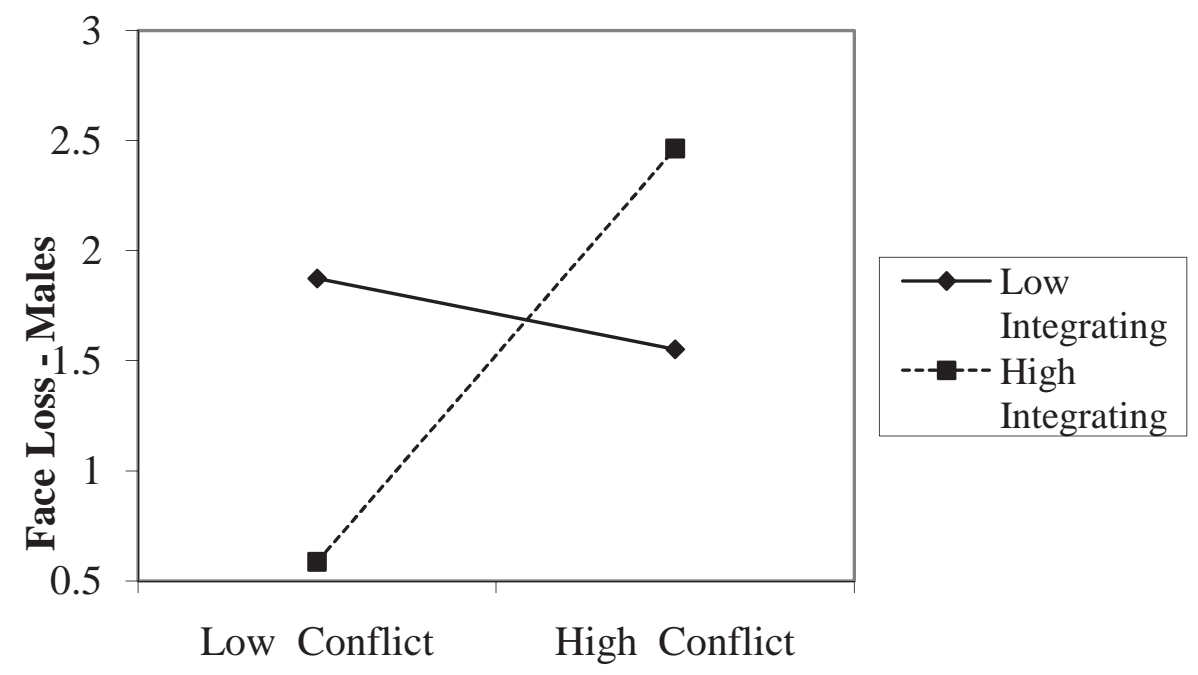


Two variables predict females' face loss, namely conflict and the interaction term conflict x avoiding facework behaviors category, which account for $25 \%$ of the variance of face loss for females. The more the conflict in a team, the higher females' face loss. The more females engages in facework behaviors from the avoiding facework category, the higher females' face loss. The interaction term conflict $\mathrm{X}$ avoiding has a positive value, that is, females adopting higher levels of the avoiding facework behaviors category in high conflict situations have higher levels of face loss.

Figure 7 shows the effect of the level of the avoiding facework behaviors category on the relationship between conflict and face loss for females. Females adopting high levels of facework behaviors related to the avoiding facework behaviors category in high conflict situations have higher face loss, while females adopting lower levels of the facework behaviors from the avoiding facework behaviors category in high conflict situations have lower face loss.

Figure 7 - Interaction effect of level of the avoiding facework category on the relationship between conflict level and face loss for females

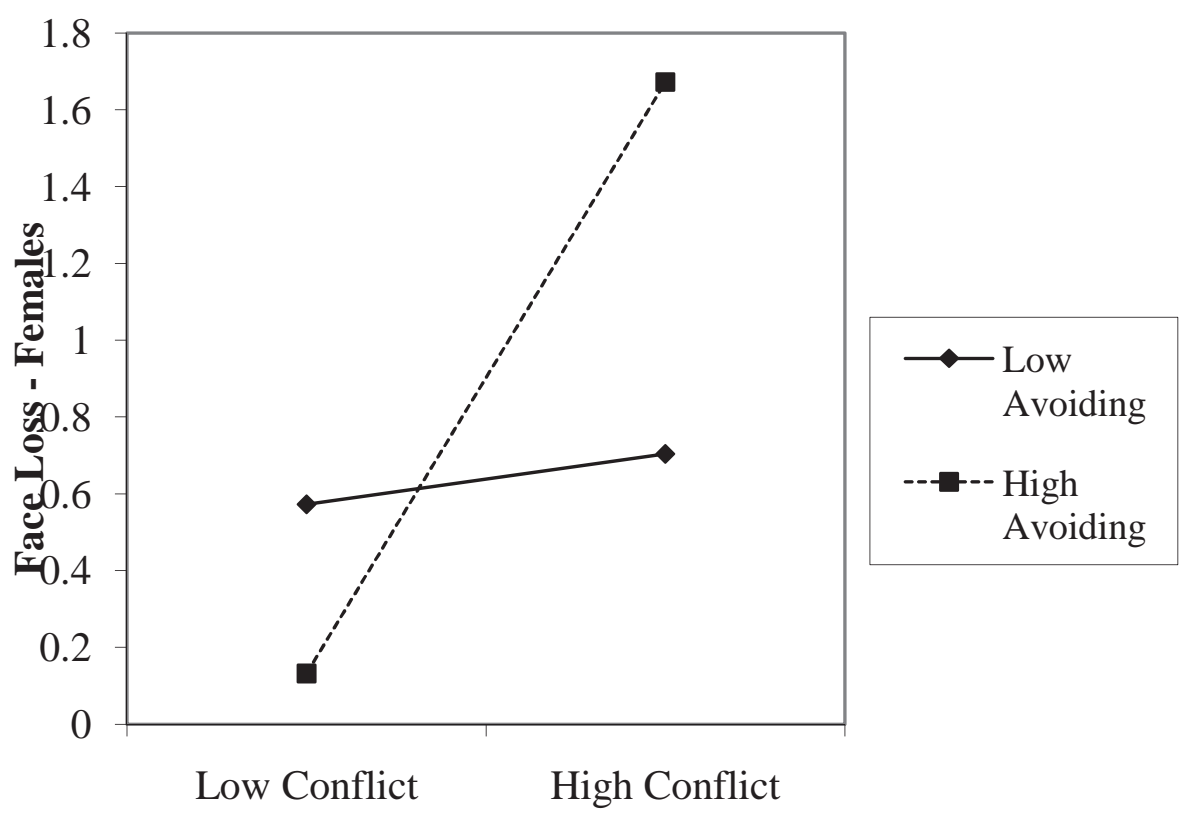


These results show that facework behaviors play a moderating role on the relationship between conflict and the outcomes of the online discussion teams. Based on the results from Tables 41, 42, 43 and 44 and Figures 5, 6 and 7, hypotheses H4 and H4.1 are supported.

\subsection{Qualitative Analysis Results}

There is no unified approach to discourse analysis (Cheek, 2004). Potter and Wetherell (1987) state that "perhaps the only thing all commentators are agreed on in this area is that terminological confusions abound" (p. 6) and later on the same page "It is a field in which it is perfectly possible to have two books on discourse analysis with no overlap in content at all." Gee (2011) argues, "like good science and good art, some of what is takes to do a good discourse analysis involves things such as taste, innovation, risk taking, and good choices (and luck) about what to study" (p. xii).

Gee (2011) recommends that one do discourse analysis through a set of "tools". He developed a set of 27 tools, where each is a specific question (or set of questions) to be asked to the data. Each question or tool makes the reader look in more detail at the language used during the communication act. Following his approach, a tool was designed for this study called the "The Facework Behavior tool" which requires the researcher to ask two questions about each student post: 1 . What are the facework behaviors used by the participants? and 2. What are the most frequent facework behaviors used by the participants? The objective with the tool is to answer the questions already mentioned. The tool helps to extract posts' fragments, which complement the qualitative results.

Before the qualitative data analysis, all posts were transferred from the online discussion board system used in this study to a Microsoft Word document to facilitate its 
analysis. The 5,223 posts of all participants, which occupy 523 pages, were reviewed. In total there were 228 facework behaviors. Examples of these posts are shown below. Only names were changed during transcription. This was done to protect the participants' real identities.

\section{Aggression}

1. "Violent video games causes premature sexualizaton, this statement is a complete joke."

2. "So you are saying...if you kill one life now as long as you save a life later it is alright? How do you know 100\% sure that it will save that life later down in the road? It is called research for a reason which means they haven't figured it out. With what you are saying is that it is okay to kill a life now so they can do their research and possibly save someone later. But, how do you know for sure? Can you have that on your conscious?

3. "Justine I think it was great that you did that research because I have always been under the impression that immigrants are the primary users of welfare. I do have one question for you, who takes up the $62 \%$ thats left over?"

\section{Defend}

1. "Yes, getting a passport may be a impossible task for many citizens of other countries, but simply allowing people to risk their lives by crossing the border illegally would be an injustice served by both countries (the country of origin and the United States.)"

2. "Well I agree with some of your points there about not being able to track down all the illegal immirgants and all that, but that is why this system is nessesary"

3. "What I meant in regards to this is that even if the government were to successfully implement this system, I don't believe the system would be beneficial towards accomplishing the goals that might be put in place (ie. deportation of illegal immigrants)."

\section{Respect}

1. "Could you explain your last point in more detail please?"

2. "Although I think understand the point your trying to get across, I have to disagree with what you said about being were born here and not succeeding then you a couch potato who wants easy money"

3. "Martina, I disagree with you at the point that illegal immigrants do not pay taxes. Actually they do pay, just as anyone of us. But they cannot get the tax return as we do. So they actually do not get government resources for free."

\section{Problem Solve}

1. "So i see your point there in using this system to send illegal immigrants home after all they are illegal. But we have to also see in their shoes and see all the things that are happening in the places they are living."

2. "i big time disagree with the first statements that samuel was making, it seemed like he just didnt care about these people and they were some kind of hard core criminals, its true that they have broken some laws but sometimes good people go to extremes to find a way out from the misery of their past lives and 
we being the number one country are there only hope to survive for them with some peace in their mind that they have tried to succeed in their limitations. Who doesnt want the best for their families?, then samuel in a later post seemed like he started to realize that these were people with families so i opened my mind to anything else he had to say"

3. "I Gabriela agree with Jennifer comment that our goverment should pass some kind of bill to make illegal immigrants legal in the U.S.A. I am not stating make all illegal immigrants legal just illegal immigrants that can prove with proper documentation that they have been in the U.S.A. for a certain amount of time (the goverment can set the amount of time maybe 5 years) and that also hold a stable job.This would help our economy a lot. We would be able to collect more taxes from them. I strongly agree with Jennifer."

\section{Apologize}

1. "I apologize if my post came off as too aggressive, I was merely addressing your comments in the hopes you would understand why some of them may not be valid."

2. "Sorry you guys, I feel like I am being a little bias:) but I am strongly against this study."

3. "ok. sorry i dont mean to sound like a pushy person"

\section{Express Emotions}

1. "Okay well I am personally against the implementation of such a system"

2. "i have nothing against illegal immigrants, $i$ know a majority of them are hard working people who come to this country in hopes of a better live and future. I know a couple of really close friends $n$ family member who are illegal immigrants and all they want is to be respected and have the same rights as every American because they don't just take but they also pay their dues like every citizen."

3. "Illegal immigration is a touchy subject because a lot of people have family that are illegal immigrants. They may also have origins of illegal immigration. It is a touchy subject that must be handled with care but also must be met. There needs to be considerable reform that everyone can agree on."

\section{Remain Calm}

1. "Like I mentioned in the other post, I think you are misinterpreting my point."

2. "Gustavo, you have misunderstood my point. When I say premature sexualization, it doesn’t imply children "getting it off with a video game.” It means that children may use inappropriate language or behavior they hear from the violent video games that children would normally not use at their age."

Give in

1. "I would like to change my stance on this matter and agree with John that each case shouldn't be treated individually. It is clear that illegal immigration is illegal, and there should be no exceptions if this system is implemented"

\section{Third Party}

1. " Hey Pete, it looks like you do not understand my point. Could you ask Johanna to see if she can clarify it?" 


\section{Private discussion}

1. "Could we talk tonight? Call me at 888-888-8888, honestly, I do not want everybody else to read my comments to your last post."

\subsubsection{Qualitative Research Findings}

As a result of the qualitative analysis, Table 45 shows the facework behaviors ordered by frequency. There is to point out that the first seven facework behavior from Table 45 correspond with the highest seven facework behaviors from Table 47 (ordered by mean), which means that the facework behaviors with the seven highest means are the facework behaviors with the highest frequencies (defend, express emotions, respect, problem solve, apologize, and remain calm), with the exception of aggression. Figure 9 shows a graph with the data from Table 47.

Table 45 shows that five out of the seven highest frequencies correspond to the facework category integrating. Moreover, results from Tables 46 and 48 show that the ranking of the facework behaviors categories, ordered by frequency or mean is: integrating, dominating and avoiding. This could be an artifact of the assignment, where one of the last steps to complete it requires that participants should agree in a unified team position, which could have influenced the integrating facework behaviors category means. Table 46 shows the facework behaviors categories ordered by frequency and Figure 8 shows a graph with the data from Table 45.

Results from Table 46 (frequency) are aligned with the results from Table 45 (means), where the integrating facework behavior category is the one with the highest mean, followed by the categories dominating and avoiding.

Facework behaviors categories divided by sex and ordered by frequency and mean show similar results to the overall data (see Tables 46 and 48). The facework behaviors in descending order are integrating, dominating, and avoiding. In addition, females have higher frequencies and means on all three facework behaviors categories 
than males. However, it is not the case for all eleven facework behaviors (see Tables 45 and 47).

Table 45. Frequency of Facework Behaviors

\begin{tabular}{|l|l|c|c|c|}
\hline \multicolumn{1}{|c|}{ Facework } & Facework Behavior & $\begin{array}{c}\text { Males / } \\
\text { Females }\end{array}$ & Males & Females \\
\hline Dominating & Defend & 73 & 41 & 32 \\
\hline Integrating & Respect & 63 & 18 & 45 \\
\hline $\begin{array}{l}\text { Dominating, } \\
\text { Integrating }\end{array}$ & Express Emotions & 54 & 20 & 34 \\
\hline Integrating & Problem Solve & 13 & 4 & 9 \\
\hline Integrating & Apologize & 13 & 4 & 9 \\
\hline Dominating & Aggression & 7 & 5 & 2 \\
\hline Integrating & Remain Calm & 2 & 1 & 1 \\
\hline Avoiding & Give in & 1 & 1 & 0 \\
\hline Avoiding & Third Party & 1 & 0 & 1 \\
\hline Integrating & Private Discussion & 1 & 0 & 1 \\
\hline Avoiding & Pretend & 0 & 0 & 0 \\
\hline Total & & 228 & 94 & 134 \\
\hline
\end{tabular}

Table 46. Frequency of Facework Behaviors Categories

\begin{tabular}{|l|c|c|c|}
\hline Facework Behavior Category & $\begin{array}{c}\text { Males / } \\
\text { Females }\end{array}$ & Males & Females \\
\hline Integrating & 146 & 47 & 99 \\
\hline Dominating & 134 & 66 & 68 \\
\hline Avoiding & 2 & 1 & 1 \\
\hline
\end{tabular}


Figure 8 - Frequency of Facework Behaviors

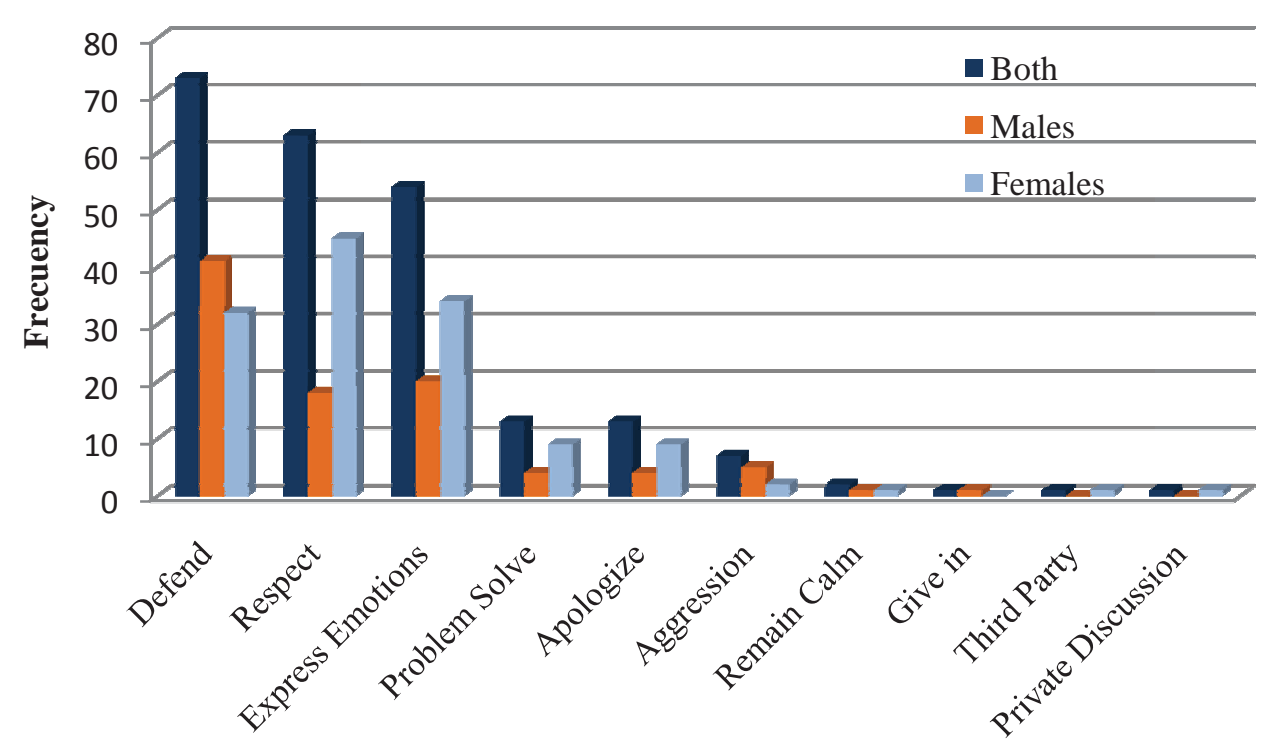

Facework Behaviors

Table 47. Facework Behaviors ordered by Mean

\begin{tabular}{|l|l|l|l|l|l|l|l|}
\hline \multirow{2}{*}{$\begin{array}{c}\text { Facework } \\
\text { Category }\end{array}$} & \multirow{2}{*}{ Facework Behavior } & \multicolumn{2}{c|}{$\begin{array}{c}\text { Males / } \\
\text { Females }\end{array}$} & \multicolumn{2}{c|}{ Males } & \multicolumn{2}{c|}{ Females } \\
\cline { 3 - 9 } & & Mean & SD & Mean & SD & Mean & SD \\
\hline Integrating & Respect & 4.05 & .61 & 3.95 & .63 & 4.17 & .55 \\
\hline $\begin{array}{l}\text { Dominating, } \\
\text { Integrating }\end{array}$ & Express Emotions & 3.74 & .79 & 3.66 & .86 & 3.84 & .67 \\
\hline Integrating & Remain Calm & 3.61 & .95 & 3.63 & 1.16 & 3.60 & .59 \\
\hline Integrating & Problem Solve & 3.61 & .62 & 3.50 & .64 & 3.75 & .56 \\
\hline Dominating & Defend & 2.97 & .53 & 2.99 & .61 & 2.94 & .61 \\
\hline Integrating & Apologize & 2.81 & .78 & 2.75 & .74 & 2.89 & .83 \\
\hline Avoiding & Give in & 2.79 & .82 & 2.74 & .85 & 2.85 & .78 \\
\hline Integrating & Private Discussion & 2.73 & .71 & 2.65 & .69 & 2.84 & .74 \\
\hline Avoiding & Pretend & 2.64 & .66 & 2.58 & .68 & 2.71 & .63 \\
\hline Avoiding & Third Party & 2.60 & .71 & 2.61 & .73 & 2.59 & .68 \\
\hline Dominating & Aggression & 1.58 & .68 & 1.62 & .71 & 1.52 & .64 \\
\hline
\end{tabular}


Table 48. Means of Facework Behaviors Categories

\begin{tabular}{|l|c|c|c|}
\hline $\begin{array}{c}\text { Facework Behavior } \\
\text { Category }\end{array}$ & $\begin{array}{c}\text { Males / } \\
\text { Females }\end{array}$ & Males & Females \\
\hline Integrating & 3.43 & 3.35 & 3.52 \\
\hline Dominating & 2.76 & 2.76 & 2.77 \\
\hline Avoiding & 2.68 & 2.64 & 2.72 \\
\hline
\end{tabular}

Figure 9 - Means of Facework Behaviors

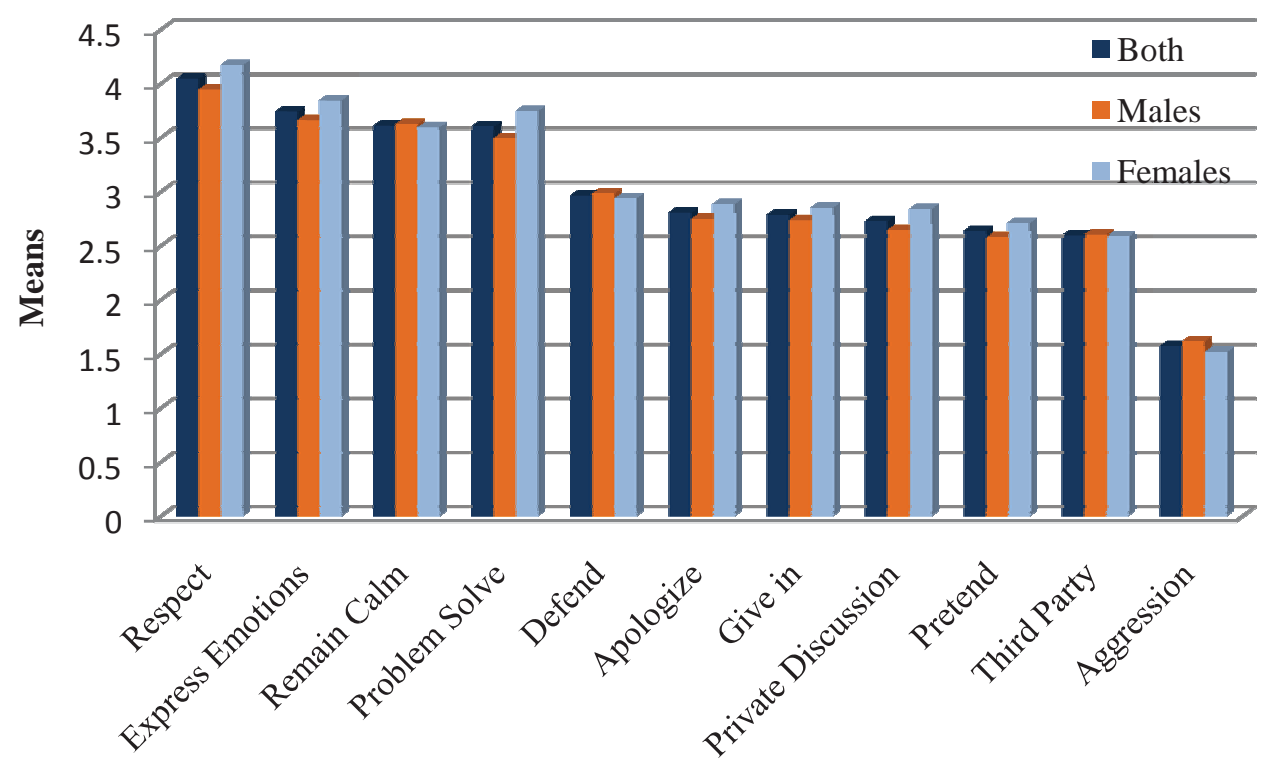

Facework Behaviors

The typology of the facework behaviors came from the analysis of face-to-face interaction and subsequent studies about this field have also considered face-to-face interactions or hypothetical conflict scenarios (Oetzel et al. 2000; Oetzel et al. 2001; Oetzel et al. 2003; Oetzel et al. 2007; Walsh et al. 2003; Baranova 2010). In a face-toface interaction, participants can use all their senses to analyze the interaction process in real time and they can detect any change based on the other participants' gestures, and voice tone, among other clues. According to Harasim (1990), among the differences between computer-mediated and face-to-face discussions are: time dependence, place 
independence, the structure of communication and the richness of the communication. These differences allow participants in online discussions more time to react to other's acts, but participants are limited in terms of the visual cues that they can detect from other participants because they are only limited to text-based communication.

During the qualitative analysis of posts, the facework behavior pretend (pretending that there is not conflict or that you are not upset or hurt by what has happened) did not show up. Pretend is difficult to detect, in principle, because it is hard to determine, just from written text, when a participant is upset and when he/she is behaving as if nothing has happened. In a face-to-face interaction, it would be easier to observe changes in other participants' behaviors.

Another aspect that shows up during qualitative analysis of posts is that when participant A feels an aggression from participant B, in all the cases (7), participant B responded with a defense facework behavior. Two examples appear below. In both cases, participants are discussing the implementation of an illegal immigration system.

Example 1

Participant A - Facework Behavior: Aggression

"just seems like all of this would create an even bigger bureaucracy than what is already in place, people will come here regardless of what laws are in place, for the most part they are coming seeking a better life, i know the argument is "they should do it the right way" what way is that? there is no right way, the only way to get a passport in mexico is to have sizable holdings (property, bank accounts) there so that they are confident that you will not just leave and not come back, if such were the case in the united states i doubt that you or anyone here in this group would get a passport, it is up to the U.S. to help these people, not scare them away with these bunk laws"

\section{Participant B - Facework Behavior: Defend}

"Yes, getting a passport may be a impossible task for many citizens of other countries, but simply allowing people to risk their lives by crossing the border illegally would be an injustice served by both countries (the country of origin and the United States.)" 


\section{Example 2}

\section{Participant A - Facework Behavior: Aggression}

"then if it is true that immigration has slowed to a trickle then why not just grant all of the illegals that are here amnesty? if mexico is such an attractive place then why as Americans are we so scared to give someone who fought tooth and nail over here citizenship? we did it in the 80's and the country didn't explode"

\section{Participant B - Facework Behavior: Defend}

"If the issue is not with our immigration system but is with the rulings of a foreign government then there is little the United States can do. The United States should not have the right to completely disregard the rulings of these foreign governments. However, if the United States does intend to challenge these governments, it should do it openly and diplomatically. " 


\section{Chapter 7 - Discussion and Implications}

The established typology of facework behaviors (Oetzel et al., 2000) is based on face-to-face interactions and has not been extended to online discussion teams. Face is an important concept, and it is carried with the individual into his/her social, face-to-face or online encounters. This research analyzed the role that facework behaviors plays in conflicts and online discussion outcomes, and the facework behaviors' moderating effect on the relationship between the conflicts and online discussion outcomes. Based on previous studies, the role of sex is also considered.

Results showed: 1 . facework behaviors are related to both conflicts and online discussion outcomes; 2. conflicts influence online discussion outcomes; 3. facework behaviors moderate the relationship between conflicts and online discussion; and 4 . sex plays a role in the participants' preferences for facework behaviors. In addition, like in Rodelberg and Rumery (1996), where team decision quality increased as the number of men in team increased; and in Pelled (1996), where teams with members from both genders displayed more relationship conflicts than teams that did not include both; this study shows a differentiation based on sex in terms of satisfaction and face loss.

Prior studies show that face loss has direct consequences on future interpersonal interactions (Brown and Levinson, 1987; Hodgins et al. 1996). Kam and Bond (2008), in a study about the role of emotions on the impact of face loss on relationship deterioration between the Chinese and Americans, found that face loss accounted for 27\% (US) and 35\% (Hong Kong) of the variance in relationship deterioration. Even though Chinese participants had higher relationship deterioration due to face loss, for the US participants face loss accounts for more than a quarter of variance in relationship deterioration (see Figure 10). 


\section{Figure 10. Direct Face Loss effect on Relationship Deterioration}

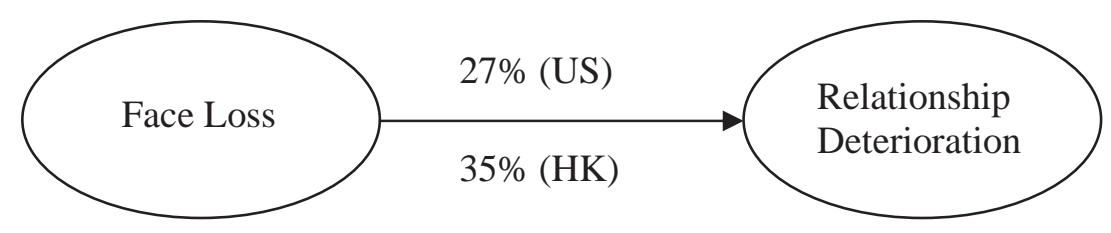

Negotiation is an area where face is important given the many ways and opportunities for a person's face to be threatened (White et al., 2004). In a negotiation, when a negotiator's face is threatened, his/her behavior can change from cooperation to competition, reducing the opportunities for an agreement and/or bringing about lesscooperative agreements (White et al., 2004). Wilson (1992) states that the concept of face must be part of any theory of negotiation processes and outcomes. From the information systems perspective, the purpose of a Negotiation Support Systems (NSS-a type of Group Decision Support Systems (Fjermestad and Hiltz, 1999) is to support negotiations. Technology, especially the Internet, has facilitated the access to a broader range of negotiators, regardless of time and place barriers. According to Lim and Yang (2007), NSS offers the possibility to help in the problem-solving process and to reduce the cognitive and socio-emotional load towards a successful negotiation. However, the communication media may impact the socio-emotional communication imposed by the restrictions in terms of the transmission of non-verbal cues, such as body gesture and voice tone, which could influence a negotiation. Particularly, asynchronous computermediated communication may reduce the interchange of socio-emotional messages (Yuan et al., 2003).

Face (or the losing of it) is related to knowledge management, where according to Tong and Mitra (2009) in a study conducted on a Chinese mobile phone company, older members were unwilling to hear different opinions from younger members, because they had fear of losing face. In addition, junior employees, from the same Chinese 
company, also show concern for losing face because they do not want to ask others when they do not know something and thereby show weakness. As a consequence, junior employees waste time searching for answers to their questions instead of taking advantage of the team's knowledge.

Implications and limitations of this study and suggestions for future studies are presented next.

\subsection{Implications for practitioners}

Implication for practitioners are presented next:

- Keeping a positive face is important in an online course environment. Walsh et al. (2003) found that regardless of cultural heritage, the majority of the participants in their study considered important the establishment of positive face in an online course environment. According to Yang et al. (2006) it also is important to maintain a safe online environment, where participants can feel comfortable in exchanging ideas. In order to minimize the loss of face from intra-group conflicts, and based on Oetzel et al. (2008), it is recommended to train online discussion board participants about face and facework, as a way to improve team performance. According to Oetzel et al. (2008) the training program should consider cultural differences.

- This study found that the outcome satisfaction was correlated with face loss, $r=-.28, p<.01$. This correlation is even bigger when sex was considered. For males the correlation between satisfaction and face loss was not significant, nevertheless, for females, satisfaction was significantly correlated with face loss, $r=-.46, p<.01$. Based on this result, it is important for the IS field to consider the role that facework behaviors and sex play on conflictive situations within any online setting in an attempt to increase the satisfaction and decrease the consequences from face loss for online participants. Its 
recognition is a starting point to deepen the study of human behaviors in on online environment.

\subsection{Limitations}

This study has a number of limitations, which include:

- All the data was gathered is coming from an educational setting, which limits the generalizability of the results. Nevertheless, it provides invaluable insights towards future studies in this area. Differences could arise in a company, where a discussion board is set up to discuss specific, real problems related to the company and participants engage in meaningful discussions. Moreover, if participants know that they will interact with each other more than one time, they could be more mindful about their face.

- The online discussion board is an asynchronous tool where participants interact with each other not at the same time. This can reduce the level of conflict between the participants because they have more time to think, reflect, and react to the posts of the other participants. Moreover, in the discussion board where participants only communicated through written text, non-verbal behavior such as gestures, facial expressions, and tone of the voice are missing, which reduces the probabilities of conflicts.

- A possible limitation of this study is due to the researcher subjectivity of the qualitative analysis of the students' posts. Due to a lack of resources the researcher was not able to hire independent reviewers to compare and validate the results from the qualitative analysis.

- Another limitation refers to the set of topics that could be analyzed in an educational setting. Some topics are more conflictive than others and could have generated richer data. For example: a. the right of gay couples to get married, or b. the 
legalization of drugs. Both topics are extremely conflictive, given IRB constraints it was not possible to use them.

- The range of the participants' ages was limited which reduced the opportunity to analyze the effect of this variable. Tong and Mitra (2009) exemplify a case where age plays a role on employee face loss.

\subsection{Future Studies}

Based on the results of this study and the experience executing it, a set of recommended changes for future studies include:

- Select a sample where participants will have to work with each other more than one time. The fact that team members will have to interact with each other more than one time, will make them more aware of their face and in consequence they will embrace more facework behaviors.

- Select a sample with a wider range of ages to analyze the influence of the variable age in the research model. In this study, like in Canelon et al. (2011a) the variable age (75\% of the participants' ages are in the range $20-25$ years) did not play a role in any of the regression analyses performed.

- Use a synchronous system, such as instant messaging, where the participants have to respond to other comments in real time and not at a different time like with the online discussion board (asynchronous system), however at the same time it is a constraint because it would reduce the number of participants in the study, especially if the team members are from different time zones.

- Use different communication channels. In addition to instant messaging (text only), where participants could communicate with each other through different communicational channels (audio or video or audio and video) and analyze the influence the facework behaviors under diverse communication settings. 
- This study considered the eleven facework behaviors based on the categorization of integrating, avoiding and dominating facework behaviors suggested by Oetzel et al. (2000, 2001). In order to analyze in more details the influence of every one of the facework behaviors in the relationship between conflict and outcomes, a future study could study them and explore if some facework behaviors are more relevant than others during conflict in online discussions.

- This study considered a conflict's index based on the three types of conflict (task, process, and relationship - Jehn 1995; Jehn \& Mannix 2001). In order to analyze in more detail the effect of every one of the three types of conflict on the teams' outcomes, a future study could explore how some facework behaviors are more related to a specific type of conflict than others.

- Even though in this study there was not any preference about how the groups were created in terms of sex (random allocation), a future study could consider the creation of just males, just females and mixed sex teams to analyze the influence of sex on the research model (see Figure 4 in Chapter "4").

- This study only considered one culture and based on the fact that the typology came from a sample with Japanese and US participants (Oetzel et al. 2000), a future study should consider participants from different cultures and explore the influence of the facework behaviors on the online discussion outcomes across the cultures.

- A couple of ideas subjected to IRB approval are: 1 . Select a sample from a non-educational setting with fewer constraints at the time to choose to topic to be discussed by the participants of the online discussion board in order to be able to pick up more controversial topics to encourage more conflict, and 2. Designate a member of the team who will play the role to be against any idea from any other team member, with the purpose to generate more conflict between the participants. 
This study has shown that face is not only important in face-to-face but in online interactions as well. The results of this study show that during conflict in online discussion, facework behaviors play a role on the outcomes in online discussion, even in a low level of conflict between the participants. It is expected that the facework behaviors play a more prominent role on more conflictive situations and that some facework behaviors will influence the outcomes more than others due to the nature of the communication channel. Hopefully, addressing the limitations and recommendations, future studies can deepen the analysis of face in different online scenarios where face has been or has been not considered. 


\section{References}

1. Andriessen, J., G. Erkens, E. Overeem, and Jasper, J. (1996). Using complex information in argumentation for collaborative text production.

2. Baker, M. \& Bielaczyc, K. (1995). Missed opportunities for learning in collaborative problem-solving interactions. In. J. Greer (Ed.), proceedings of AI-ED 95 - World Conference on Artifical Intelligence in Education. pp.210-218.

3. Baxter, L. A. (1984).An investigation of compliance-gaining as politeness. Human Communication Research, 10, 427-456.

4. Baranova, E. (2010). Facework in organizational conflict: A cross-cultural study comparing Russians and Americans. (UMI No. 1477626 )

5. Brown, P., \& Levinson, S. (1978). Universals in language usage: politeness phenomena. In E. Goody (Ed.) Questions and Politeness: Strategies in social interaction (pp. 56-289). Cambridge: Cambridge University Press.

6. Brown, P., \& Levinson, S. (1987). Politeness: Some universals in language usage. Cambridge, UK: Cambridge University Press.

7. Boulding, Kenneth. (1963). Conflict and Defense. New York: Harper \& Row.

8. Burke, M. \& Kraut, R. (2008). Mind Your Ps and Qs: The impact of politeness and rudeness in online communities. Proceedings of the 2008 ACM conference on Computer supported cooperative work.

9. Campion, M. A., Papper, E. \& Medsker, G. (1996). Relations between work team characteristics and effectiveness: A replication and extension. Personnel Psychology, 49, 439-452. 
10. Canelon, J., Ryan, T., Moss, F. \& Prasertsilp, P. (2011a). Facework, Gender, and Online Discussion. Proceedings of the 6th Annual Conference of the Midwest Association for Information Systems.

11. Canelon, J., \& Ryan, T. (2011b). Conflict in Online Discussion.

12. Chan, C., Burtis, J. and Bereiter, C. (1997). Knowledge building as a mediator of conflict in conceptual change. Cognition and Instruction, 15, 1-40.

13. Cheek, J. (2004). At the margins? Discourse analysis and qualitative research. Qualitative Health Research, 14, 8, 1140-1150.

14. Cox, E., Clark, W., Heath, H. and Plumpton, B. (2000). "The Impact of Gender on Effective Online Discussion Groups". Retrieved online from http://www.unisanet.unisa.edu.au/cccc/papers/refereed/paper12/Paper12-1.htm on September the $29^{\text {th }} 2011$.

15. Craig, R., Tracy, K. \& Spisak, F. (1986). The discourse of requests. Assessment of a Politeness Approach. Human Communication Research, 12, 4, 437-468.

16. Cupach, W. R., \& Metts, S. (1994). Facework. Thousand Oaks, CA: Sage.

17. Dawe, H. (1934). The influence of the size of kindergarten group on performance. Child development, 5, 295-303.

18. de Dreu, C. \& Weingart, L. (2002). Task versus relationship conflict: A metaanalysis. Academy of Management Proceedings, B1-B6.

19. Deeter-Schmelz, D., Kennedy, K. \& Ramsey, R. (2002). Enriching our understanding of student team effectiveness. Journal of Marketing Education, 24, 2, $114-124$

20. De Jong, R., Schalk, R. \& Cur eu. (2008). Virtual communicating, conflicts and performance in teams. Team Performance Management, 14, 7/8, 364-380. 
21. De Jong, M., Theune, M. \& Hofs, D., (2008). Politeness and alignment in dialogues with a virtual guide. Proceedings of the $7^{\text {th }}$ International Conference on Autonomous Agents and Multiagent Systems.

22. Deutsch, Morton. (1961). The face of bargaining. Operations Research, 9, 886-897.

23. DeWert, M. H., Babinski, L. M. and JOnes, B. D. (2003). Safe Passages: Provinding Online Support to Beginning Teachers, Journal of Teacher Education, 54, 4, 311.

24. Doise, W \& Mugny, G. (1984). The social development of the intellect. Oxford: Pergamon Press.

25. Eelen, Gino. (2001). A Critique of Politeness Theories. St John's Publishers, Manchester.

26. Eryilmaz, E., Alrushiedat, N., Kasemvilas, S., Mary, J., and van der Pol, J. (2009). The Effect of Anchoring Online Discussion on Collaboration and Cognitive Load. Proceedings of the Fifteenth Americas Conferences on Information Systems, San Francisco, California, August $6^{\text {th }}$ to $9^{\text {th }}$.

27. Field, Andy (2009). Discovering Statistics using SPSS. Thousand Oaks: Sage publications.

28. Fjermestad, J. and Hiltz, S. R. (1999). An assessment of group support systems experimental research: Methodology and results. Journal of Management Information Systems, 15, 3, 7-149

29. Gallenkamp, J., Assmann, J., Drescher, M., Picot, A. \& Welpe, I. (2010). Conflict, culture, and performance in virtual teams: results from a cross-cultural study. Proceedings of the 43rd Hawaii International Conference on System Sciences.

30. Gee, J. P. (2011). How to do Discourse Analysis: A toolkit. New York: Routledge. 
31. Goffman. Erwing. (1955). On Face-Work: An analysis of ritual elements in social interaction. Psychiatry, 18, 3, 213-31.

32. Goffman, Erwing. (1967). Interaction Ritual. Anchor Books, New York.

33. Gregory, M.Y. (1997). "Gender differences: An examination of computer-mediated communication." Annual meeting of the Southern States Communication Association, Savannah, GA.

34. Gunawardena, C. N. (1998). Analysis of a global debate and the development of an interaction analysis model for examining social construction of knowledge in computer conferencing, Journal of Educational Computing Research, 17, 4.

35. Gupta, A., Walker, M. A. \& Romano, D. M. (2007). How rude are you? Evaluating politeness and affect in interaction. Affective Computing and Intelligent Interaction, 203-217.

36. Harasim, L. M. (1990). Online Education: An Environment for Collaboration and Intellectual Amplification. In Harasim, L. M. (Ed), Online Education: Perspectives on a New Environment (pp. 39-64). NY: Praeger Publishing.

37. Hinds, P. J. \& Mortensen, M. (2005). Understanding conflicts in geographically distributed teams: The moderating effects of shared identity, shared context, and spontaneous communication. Organization Science, 16, 3, 290-307

38. Ho, D. Y. F. (1976). On the concept of face. American Journal of Sociology, 81, 867-884.

39. Hodgins, H. S., Liebeskind, E. and Schwartz, W. (1996). Getting out of hot water: Facework in social predicaments. Journal of Personality and Social Psychology, 71, 300-314. 
40. Hui, Victoria \& Bond, Michael. (2009). Target's face loss, motivations, and forgiveness following relational transgression: Comparing Chinese and US cultures. Journal of Social and Personal Relationships, 26(2-3), 123-140.

41. Hutson-Comeaux, S. \& Kelly, J. (1996). Sex differences in interaction styles and group task performance: The process-performance relationship. Journal of Social Behavior \& Personality, 11, 5, 255-275.

42. Jehn, K. A. (1995). A multimodal examination of the benefits and detriments of intragroup conflict. Administrative Science Quarterly, 40, 256-82.

43. Jehn, K. A. (1997). A qualitative analysis of conflict types and dimensions in organizational groups. Administrative Science Quarterly, 42, 530-57.

44. Jehn, K. A. \& Mannix, E. A. (2001). The dynamic nature of conflict: A longitudinal study of intragroup conflict and group performance. Academy of Management Journal, 44, 2, 238-251.

45. Jehn, K. A. \& S.M.B. Chadwick (1997). To agree or not to agree: The effects of value congruence, individual demographic dissimilarity, and conflict on workgroup outcomes. International Journal of Conflict Management, 8, 4, 287-305.

46. Johnson, D. \& Johnson, F. (1994). Joining together: Group theory and group skills. Boston: Allyn \& Bacon.

47. Kam, Chester \& Bond, Michael. (2008). Role of emotions and behavioral responses in mediating the impact of face loss on relationship deterioration: Are Chinese more face-sensitive than Americans? Asian Journal of Social Psychology, 11, 175-184.

48. Kanuka, H. and Anderson, T. (1996). Online social interchange, discord and knowledge construction, Journal of Distance Education, 13, 1, 57-74. 
49. Kerssen-Griep, J., Trees, A. \& Hess, J. (2008). Attentive facework during instructional feedback: Key to perceiving mentorship and an optimal learning environment. Communication Education, 57, 3, 312-332.

50. Levine, J. (2007). The online discussion board. New directions for adult and continuing education, 113, 67-74.

51. Lim, T. S. \& Bowers, L. (1991). Face-work Solidarity, approbation, and tact. Human Communication Research, 17, 415-450.

52. Lim, Tae-Seop. (1994). Facework and Interpersonal Relationships. In Ting-Toomey, E. (Ed.) The challenge of facework: cross-cultural and interpersonal issues (pp. 209230). Albany, NY: State University of New York.

53. Lim, J. and Yang, Y. (2007). Enhancing negotiators' performance with computer support for pre-negotiation preparation and negotiation: An experimental investigation in an East Asian context. Journal of Global Information Management, $15,1,18-42$.

54. Lin, Yü-tang. (1935). My Country and My People. New York: Reynal \& Hitchcock.

55. Liu, Y. \& Burn, J. (2007). Improving the performance of online learning teams - A discourse analysis. Journal of Information Systems Education. 18, 3, 369-379.

56. Liu, X., Magjuka, R., \& Lee, S. (2008). The effects of cognitive thinking styles, trust, conflict management on online students' learning and virtual team performance. British Journal of Educational Technology, 39, 5, 829-846.

57. Martinez-Moreno, E., Gonzalez-Navarro, P., Zornoza, A. \& Ripoll, P. (2008). Relationship, task, and process conflicts on team performance. The moderating role of communication media. International Journal of Conflict Management, 20, 3, 251268. 
58. Mitchell, J. (2003). On-line writing: a link to learning in a teacher education program, Teaching and Teacher Education, 19, 1, 127-143.

59. Morand, D. \& Ocker, R. (2003). Politeness theory and computer-mediated communication: A sociolinguistic approach to analyzing relational messages. Proceedings of the 36rd Hawaii International Conference on System Sciences.

60. Oetzel, J., Ting-Toomey, S. (2003). Face concerns in Interpersonal Conflict. Communication Research, 30, 6, 599-624.

61. Oetzel, J., Ting-Toomey, S., Chew-Sanchez, M. I., Harris, R., Wilcox, R. \& Stumpf, S. (2003). Face and facework in conflicts with parents and siblings: A cross-cultural comparison of Germans, Japanese, Mexicans, and U.S. Americans. Journal of Family Communication, 3, 2, 67-93.

62. Oetzel, J., Ting-Toomey, S., Yokochi, Y., Masumoto, T., \& Takai, J. (2000). A typology of facework behaviors in conflicts with best friends and relative strangers. Communication Quarterly, 48, 4, 397-419.

63. Oetzel, J., Ting-Toomey, S., Masumoto, T., Yokochi, Y., Pan, X., Takai, J. \& Wilcox, R. (2001). Face and Facework in Conflict: A cross-cultural comparison of China, Germany, Japan, and the United States. Communication Monograph, 68, 3, 235-258.

64. Oetzel, J., García, A., \& Ting-Toomey, S. (2007). An analysis of the relationships among face concerns and facework behaviors in perceived conflict situations. International Journal of Conflict Management, 19, 4, 382-403.

65. Palloff, R. M., and Pratt, K. Building Learning Communities in Cyberspace. San Francisco: Jossey-Bass, 1999. 
66. Pelled, L. H. (1996) Relational demography and perceptions of group conflict and performance: A field investigation. International Journal of Conflict Management, 7, 3, 230-246.

67. Petraglia, J. (1998). The rhetoric and technology of authenticity in education. Mahwah, NJ: Lawrence Erbium.

68. Piaget, J. (1978). The development of thought: Equilibrium of cognitive structures. New York: Viking Penguin.

69. Potter, J. \& Wetherell, M. (1987). Discourse and social psychology. London: Sage.

70. Robson, Colin (2002). Real World Research. Blackwell Publishing.

71. Rodelberg, S. G. \& Rumery, S. (1996). Gender diversity, team decision quality, time on task, and interpersonal cohesion. Small group research, 27, 1, 79-90.

72. Rogan, R. G. \& Hammer, M. R. (1994). Crisis negotiations: A preliminary investigation of facework in naturalistic conflict discourse. Journal of Applied Communication Research, 22, 216-231.

73. Savery, J. \& Duffy, T. M. (1996). Problem based learning: An instructional model and its constructivist framework. In B. Wilson (Ed.), Constructivist learning environments: Case studies in instructional design (pp. 135-148). Englewood Cliffs, NJ: Educational Technology Publications.

74. Shah, P. \& Jehn, K. (1993). Do friends perform better than acquaintances? The interaction of friendship, conflict and task. Group Decision and Negotiation, 2, 149166.

75. Shimanoff, S. B. (1977). Investigating politeness. In E. O. Keenan \& T. L. Bennet (Eds.), Discourse across time and space (pp. 213-241). Los Angeles: University of Southern California. 
76. Shimanoff, S. B. (1985). Rules for governing the verbal expression of emotions between married couples. Western Journal of Speech Communication, 49, 147-165.

77. Shimanoff, S. B. (1987).Types of emotional disclosures and request compliance between spouses. Communication Monographs, 54, 85-100.

78. Souren, P. \& Ray, S. (2010). Manifested intra-group conflict in collaborative technology supported multi-cultural virtual team: Findings from a Laboratory Experiment. Proceedings of the 43rd Hawaii International Conference on System Sciences.

79. Steiner, I.D. (1972). Group process and productivity. Academic Press, New York.

80. Strijbos, Jan-Willem, Martens, Rob, Jochems, Wim, \& Broers, Nick. (2007). The effect of functional roles on perceived group efficiency during computer-supported collaborative learning: a matter of triangulation. Computers in Human Behavior, 23, 353-380.

81. Strong, J. \& Anderson, R. E. (1990). Free-riding in group projects: Control mechanisms and preliminary data. Journal of Marketing Education, 12, 61-67.

82. Summers, I., Coffelt, T. \& Horton, R.E. (1988). Work-Group Cohesion. Psychological Reports, 627-636.

83. Thomas, E. \& Fink, C. (1963). Effects of group size. Psychological Bulletin, 60, 4, 371-384.

84. Ting-Toomey, S. (1988). A face negotiation theory. In Y. Kim \& W. Gudykunst (Eds.), Theories in intercultural communication (pp. 213-235). Newbury Park, CA: Sage. 
85. Ting-Toomey, S. (2005). The matrix of face an updated face-negotiation theory. In W. Gudykunst (Eds.), Theorizing about Intercultural Communication (pp. 71-92). Thousand Oaks, CA: Sage.

86. Ting-Toomey, S. \& Kurogi, A. (1998). Facework competence in intercultural conflict: an updated face-negotiation theory. International Journal of Intercultural Relations, 22, 2, 187-225.

87. Ting-Toomey, S. \& Oetzel, J. (2001). Managing intercultural conflict effectively. Thousand Oaks, CA: Sage Publications Inc.

88. Tong, J. and Mitra, A. (2009). Chinese cultural influences on knowledge management practice. Journal of Knowledge Management, 13, 2, 49-62.

89. Tracy, K. Craig, R., Smith, M. \& Spisak, F. (1984). The discourse of requests. Human Communication Research, 10, 4, 513-538.

90. Vinagre, M. (2008). Politeness strategies in collaborative e-mail exchanges. Computers \& Education, 50, 1022-1036.

91. Walsh, S. L., Gregory, E., Lake, I. \& Gunawardena, C. (2003). Self-construal, facework, and conflict styles among cultures in online learning environments. Educational Technology Research and Development, 51, 4, 113-122.

92. Wang, N., Johnson, L., Mayer, R., Rizzo, P., Shaw, E. \& Collins, H. (2008). The politeness-effect: Pedagogical agents and learning outcomes. International Journal of Human-Computer Studies, 66, 98-112.

93. White, J. B., Tynan, R., Galinsky, A. D. and Thompson, L. (2004). Face threat sensitivity in negotiation: Roadblock to agreement and joint gain. Organizational Behavior and Human Decision Processes, 94, 102-124. 
94. Wilson, S. R. (1992). Face and facework in negotiations. In L. Putnam and M. Roloff (Eds.), Communication and Negotiation (pp. 176-205). Thousand Oaks, CA.: Sage Publications Inc.

95. Wood, L. \& Kroger, R. (2000). Doing discourse analysis. Thousand Oaks, CA: Sage Publications Inc.

96. Wood, W., Polek, D. \& Aiken, C. (1985). Sex differences in group task performance. Journal of Personality \& Social Psychology, 48, 1, 63-71.

97. Yang, M., Chen, Y., Kim, M., Chang, Y., Cheng, A., Park, Y., Bogard, T., and Jordan, M. (2006). Facilitating or Limiting? The role of politeness in how students participate in an online classroom discussion. Yearbook of the National Reading Conference, 341-356.

98. Yuan, Y., Head, M., and Du, M. (2003). The effects of multimedia communication on web-based negotiations. Group Decisions and Negotiations, 12, 2, 89-109. 


\section{Appendix}

Appendix A: Students' Assignment

To get full credit for this assignment, each team member will have to: 1 . participate(post) 10 times (or more) on the online discussion board (www.cppcis310.com/phpBB3) during the two week assignment, and 2. at the end of the assignment each team member will have to complete a survey regarding conflicts, facework behaviors and online discussion team performance at www.surveymonkey.com/s/cis310_survey.

Topic: Illegal Immigration

As a way to reduce illegal immigration in the US, the US government is studying the implementation of a system that will collect all the information gathered in the databases of institutions such as the IRS, DMV, and the US Census Bureau, and through a matching process, it will be able to detect who and where illegal immigrants are. Once detected, should illegal immigrants be deported to their country of origin or should their deportation process be studied and considered individually? Should taxes be spent on resources to study all cases?

(Note: You DO NOT have to answer the questions at the end of the topic statement. These questions are only to encourage the discussion)

Your team will be asked to assume the role of an advisory committee that would recommend to the US Congress to allow or reject the implementation of the system.

To perform the assignment, your team will complete the following set of activities:

1. Read the tutorial file attached in the e-mail sent by Jesus Herrera.

2. Comment on the reasons why they are in favor of or opposed to the implementation of the system.

3. Generate at least 5 reasons for approving the implementation of the system.

4. Generate at least 5 reasons for rejecting the implementation of the system.

5. Select a unified team position.

6. Write a document with the team's final recommendation to the US Congress.

7. Complete the survey regarding conflicts, facework behaviors and online discussion team performance at www.surveymonkey.com/s/cis310_survey.

8. Send the final document to Jesus Herrera (jhherrera@csupomona.edu)

\section{About the final team recommendations to the US Congress}

The length of the document with the final team recommendations to the US Congress will be no more than 1 page.

The sections of the final document will be:

1. Title 
2. Group members

3. Reasons for approving the topic

4. Reasons for rejecting the topic

5. State the final team's recommendation to the US Congress supported by the group's reasons.

PLEASE, do not forget to complete the survey regarding conflicts, facework behaviors and online discussion team performance at www.surveymonkey.com/s/cis310_survey 


\section{Appendix B: Survey - Conflict -Facework Behaviors - Outcomes}

\section{Section 1}

General Information

Now, you will answer to a series of items regarding, conflicts and facework behaviors you faced with your teammates of your online discussion team. In addition, you will ask about the outcomes of your work in the online discussion team in terms of team satisfaction, group process satisfaction, and face loss.

*1. Course ID:

*2. Group Number:

*3. Username(Alias):

\section{Section 2}

Task Conflict

Now you are going to respond to a series of items regarding the task conflicts that your perceived in your online discussion team during the assignment. Task conflict is an awareness of differences in points of view and opinions in relation to the group tasks. There are no right or wrong answers. For each item, please select the appropriate response according to the scale.

1. How much conflict of ideas was there in your online discussion team?

Not at all

2. How much conflict about the work you did was there in your online discussion team? Not at all

3. How often the other team members of your online discussion team had conflicting opinions regarding the work being done?

Not at all

A lot

\section{Section 3}

\section{Relationship Conflict}

Now you are going to respond to a series of items regarding the relationship conflicts that your perceived in your online discussion team during the assignment. Relationship conflicts refers to the awareness of interpersonal incompatibilities such as dislike among group members and feelings like annoyance, frustration, and irritation.

There are no right or wrong answers. For each item, please select the appropriate response according to the scale.

1. How much relationship tension was there among members of your online discussion team?

Not at all

A lot

2. How often did team members of your online discussion team get angry while working in your team?

Not at all

A lot 
3. How much emotional conflict was there among members of your online discussion team?

Not at all

A lot

\section{Section 4}

Process Conflict

Now you are going to respond to a series of items regarding the process conflicts that your perceived in your online discussion team during the assignment. Process conflict refers to the awareness of controversies in relation to topics like issues of duty and resource delegation, such as what task should perform every team member and how much responsibility every team member should get.

There are no right or wrong answers. For each item, please select the appropriate response according to the scale.

1. How often were there disagreements about who should do what in your online discussion team?

Not at all

A lot

2. How much conflict was there in your group about task responsibilities?

Not at all

A lot

3. How often did team members disagree about the time to be spent on the tasks? Not at all

A lot

\section{Section 5}

\section{Facework Behaviors}

Now you are going to respond to a series of items regarding a conflict you have had with your online discussion team members. Conflict is defined as "any intense disagreement between two parties which involves incompatible goals, needs, or viewpoints.”

We would like you to recall a conflict that you had recently with another team member of your online discussion team.

There are no right or wrong answers. We simply want to know what you were thinking and how you acted.

At this point, we would like you to consider the actual behaviors or actions you used in the conflict. Please respond with what you actually did, not what you wish you had done.

1. I tried to maintain my composure.

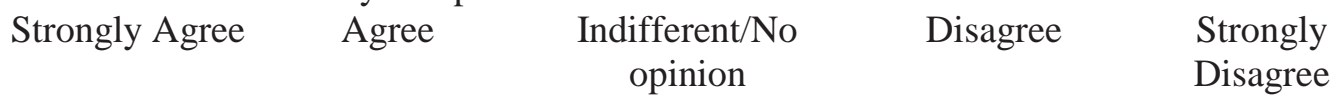

2. I apologized for my behavior. 
3. I showed sensitivity in respecting the other team member's feelings.

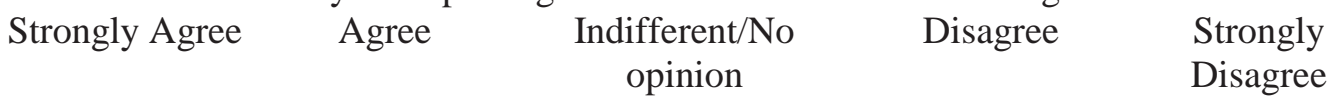

4. I didn't argue with the other team member in public.

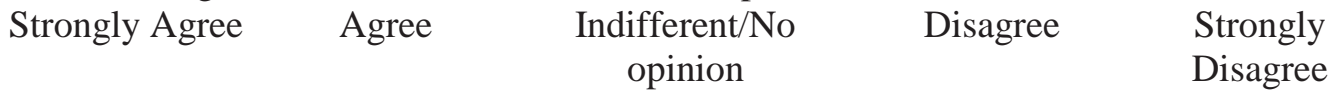

5. I tried to ask a third party to make a suggestion about how to settle the dispute.

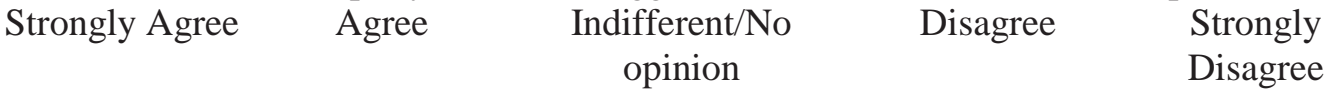

6. I acted like I wasn't upset.

Strongly Agree Agree

$\begin{array}{ccc}\begin{array}{c}\text { Indifferent/No } \\ \text { opinion }\end{array} & \text { Disagree } & \begin{array}{c}\text { Strongly } \\ \text { Disagree }\end{array}\end{array}$

7. I said bad things about the team member behind his/her back.

$\begin{array}{cccc}\text { Strongly Agree } \quad \text { Agree } & \begin{array}{c}\text { Indifferent/No } \\ \text { opinion }\end{array} & \text { Disagree } & \begin{array}{c}\text { Strongly } \\ \text { Disagree }\end{array}\end{array}$

8. I tried to insult him/her.

$\begin{array}{llll}\text { Strongly Agree } \quad \text { Agree } & \text { Indifferent/No Disagree } & \text { Strongly } \\ & & & \text { Disagree }\end{array}$

9. I tried to be firm in my demands and didn't give in.

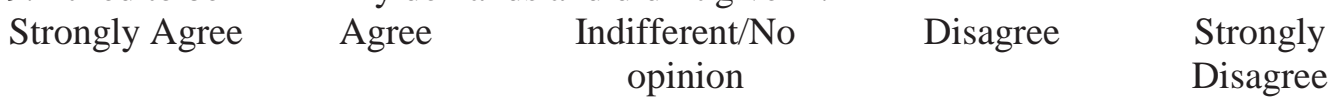

10. I tried to meet the other team member half-way.

$\begin{array}{cccc}\text { Strongly Agree } \quad \text { Agree } & \begin{array}{c}\text { Indifferent/No } \\ \text { opinion }\end{array} & \text { Disagree } & \begin{array}{c}\text { Strongly } \\ \text { Disagree }\end{array}\end{array}$

11. I worked with the other to find a mutually acceptable solution.

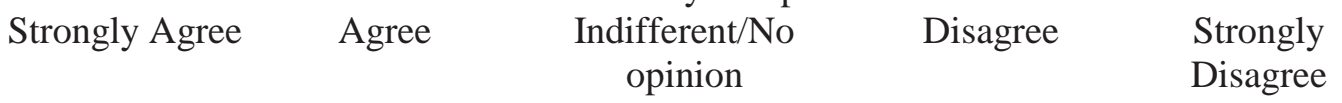

12. I tried to use "give and take" so that a compromise could be made. Strongly Agree Agree Indifferent/No Disagree Strongly 
13. I tried to ridicule the other team member.

\begin{tabular}{|c|c|c|}
\hline trongly Agree & Agree & $\begin{array}{l}\text { Indifferent/No } \\
\text { opinion }\end{array}$ \\
\hline
\end{tabular}

14. I tried to damage the other team member's reputation behind his/her back.

\begin{tabular}{|c|c|c|c|}
\hline gly Agree & Agree & $\begin{array}{l}\text { Indifferent/No } \\
\text { opinion }\end{array}$ & \\
\hline
\end{tabular}

15. I gave in, in order to end the conflict.

$\begin{array}{lccc}\text { Strongly Agree Agree } & \begin{array}{c}\text { Indifferent/No } \\ \text { opinion }\end{array} & \text { Disagree } & \begin{array}{c}\text { Strongly } \\ \text { Disagree }\end{array}\end{array}$

16. I tried to give the team member wrong information so he/she gets into trouble.

$\begin{array}{cccc}\text { Strongly Agree Agree } & \begin{array}{c}\text { Indifferent/No } \\ \text { opinion }\end{array} & \text { Disagree } & \begin{array}{c}\text { Strongly } \\ \text { Disagree }\end{array}\end{array}$

17. I proposed a middle ground for breaking the deadlock.

$\begin{array}{cccc}\text { Strongly Agree Agree } & \begin{array}{c}\text { Indifferent/No } \\ \text { opinion }\end{array} & \text { Disagree } & \begin{array}{c}\text { Strongly } \\ \text { Disagree }\end{array}\end{array}$

18. I tried to persuade the other team member to accept my viewpoint.

$\begin{array}{cccc}\text { Strongly Agree Agree } & \begin{array}{c}\text { Indifferent/No } \\ \text { opinion }\end{array} & \text { Disagree } & \begin{array}{c}\text { Strongly } \\ \text { Disagree }\end{array}\end{array}$

19. I tried to involve a third party to discuss the problem.

\begin{tabular}{|c|c|c|c|}
\hline rongly Agree & Agree & $\begin{array}{l}\text { Indifferent/No } \\
\text { opinion }\end{array}$ & Disagree \\
\hline
\end{tabular}

20. I waited until we through a different private communication channel were able to talk about the problem.

Strongly Agree

Agree
Indifferent/No opinion

Disagree

Strongly

Disagree

21. I tried to compromise with the other team member.

\begin{tabular}{|c|c|c|c|}
\hline ly Agree & Agree & $\begin{array}{l}\text { Indifferent/No } \\
\text { opinion }\end{array}$ & Disagree \\
\hline
\end{tabular}

22. I asked for forgiveness for my actions.

Strongly Agree Agree Indifferent/No Disagree Strongly 
23. I apologized even though I didn’t do anything wrong.

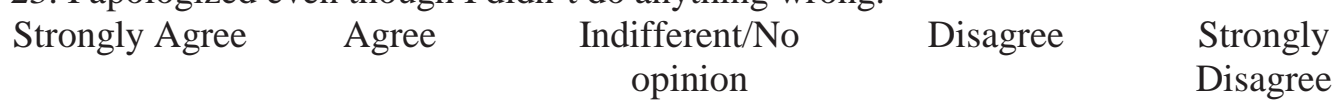

24. I tried to hurt the other team member indirectly.

Strongly Agree

opinion
opree

Disagree Strongly

Disagree

25. I tried to listen well to work on our problem.

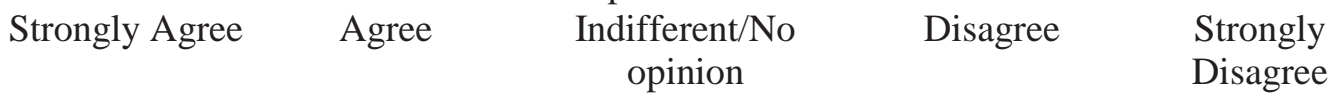

26. I listened to the other team member to show respect.

$\begin{array}{cccc}\text { Strongly Agree Agree } & \begin{array}{c}\text { Indifferent/No } \\ \text { opinion }\end{array} & \text { Disagree } & \begin{array}{c}\text { Strongly } \\ \text { Disagree }\end{array}\end{array}$

27. I used nasty words to put down the other team member.

\begin{tabular}{|c|c|c|c|}
\hline gly Agree & Agree & $\begin{array}{l}\text { Indifferent/No } \\
\text { opinion }\end{array}$ & Disagree \\
\hline
\end{tabular}

28. I pretended not to be hurt.

\begin{tabular}{|c|c|c|c|}
\hline ly Agree & Agr & $\begin{array}{c}\text { Indifferent/N } \\
\text { opinion }\end{array}$ & \\
\hline
\end{tabular}

29. I suggested contact the other team member through a different private communication channel where we could be alone to discuss the problem.

\begin{tabular}{|c|c|c|c|}
\hline igly Agree & Agree & $\begin{array}{l}\text { Indifferent/No } \\
\text { opinion }\end{array}$ & Disagree \\
\hline
\end{tabular}

30. I was direct in expressing my feelings.

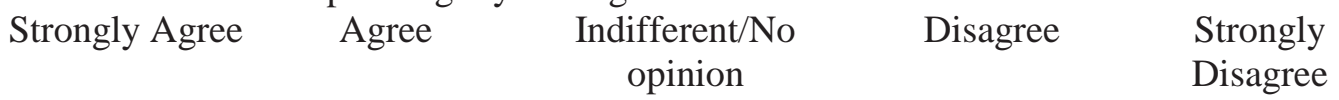

31. I admitted I made a mistake and apologized.

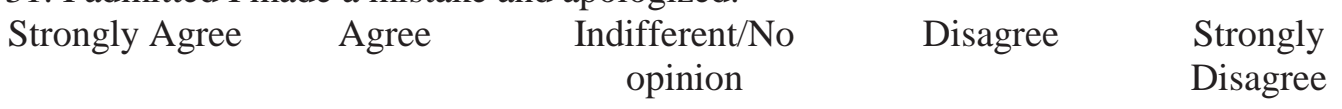

32. I tried to remain calm.

Strongly Agree Agree Indifferent/No Disagree $\quad$ Strongly 
33. I tried to ask a third person to help negotiate an agreement with the other team member.

Strongly Agree $\quad$ Agree Indifferent/No Disagree $\quad$ Strongly opinion Disagree

34. I tried to ignore the conflict and behaved as if nothing happened.

Strongly Agree Agree Indifferent/No Disagree

opinion

Strongly

Disagree

35. I called the other team member mean names.

$\begin{array}{cccc}\text { Strongly Agree } \quad \text { Agree } & \begin{array}{c}\text { Indifferent/No } \\ \text { opinion }\end{array} & \text { Disagree } & \begin{array}{c}\text { Strongly } \\ \text { Disagree }\end{array}\end{array}$

36. I tried to persuade the other team member that my way was the best way.

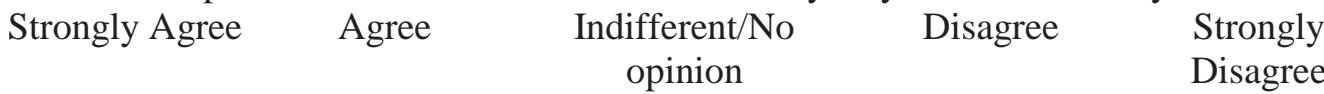

37. I tried not to get upset when we discussed the problem.

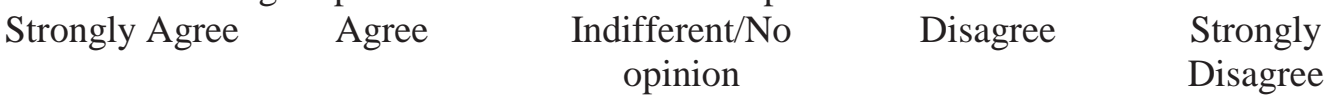

38. I tried to combine both of our viewpoints in our discussion.

\begin{tabular}{|c|c|c|c|}
\hline gly Agree & Agre & $\begin{array}{l}\text { Indifferent/N } \\
\text { opinion }\end{array}$ & \\
\hline
\end{tabular}

39. I tried to find a middle course to resolve the situation.

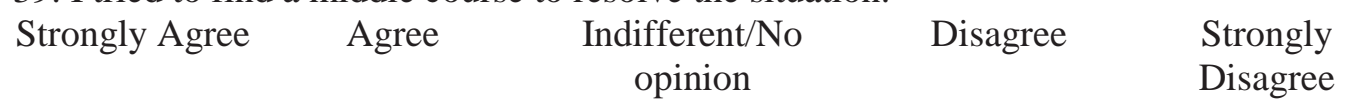

40. I gave in to the other team member's wishes.

Strongly Agree Agree Indifferent/No Disagree Strongly

opinion Disagree

41. I tried to keep our discussion private.

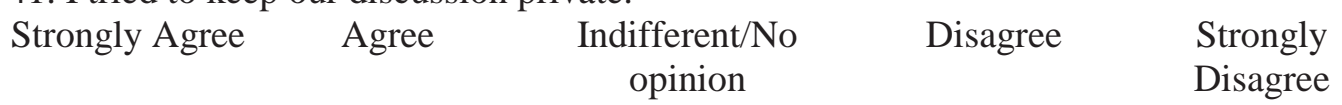

42. I tried to talk with the other team member through an outside party.

\begin{tabular}{|c|c|c|c|}
\hline gly Agree & Agree & $\begin{array}{c}\text { Indifferent/No } \\
\text { opinion }\end{array}$ & Disagree \\
\hline
\end{tabular}


43. I tried to pretend that the conflict didn't happen.

\begin{tabular}{|c|c|c|c|}
\hline gly Agree & Agre & $\begin{array}{c}\text { Indifferent/N } \\
\text { opinion }\end{array}$ & \\
\hline
\end{tabular}

44. I tried to be express my feelings in a straightforward manner.

\begin{tabular}{|c|c|c|}
\hline ngly Agree & Agree & Indifferent/No \\
\hline
\end{tabular}

45. I apologized for what was happening.

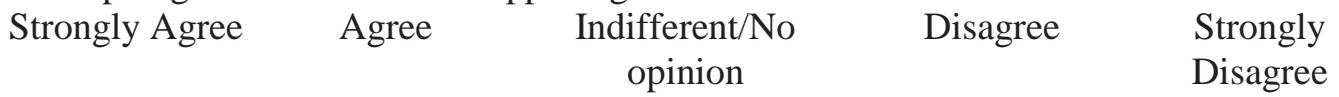

46. I tried to be considerate to show respect for the team member.

Strongly Agree Agree Indifferent/No Disagree Strongly

opinion Disagree

47. I expressed myself in a somewhat vague manner.

Strongly Agree Agree Indifferent/No Disagree Strongly

opinion Disagree

48. I "yelled" at the other team member to be disrespectful.

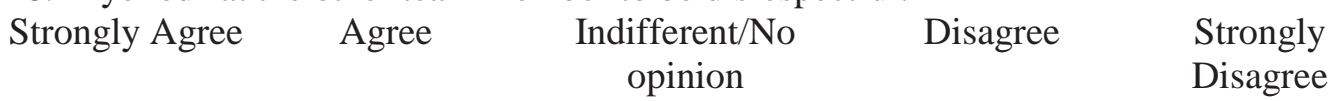

49. I tried to defend my position.

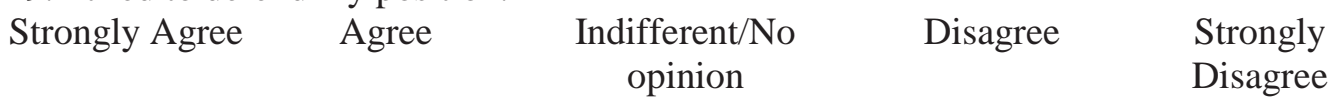

50. I agreed with the other team member to end the conflict.

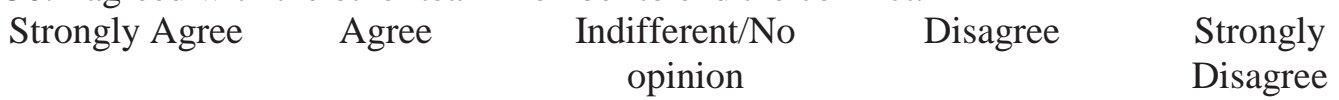

51. I tried not to discuss the problem in front of others.

\begin{tabular}{|c|c|c|c|}
\hline Agree & Agr & $\begin{array}{l}\text { Indifferent/N } \\
\text { opinion }\end{array}$ & \\
\hline
\end{tabular}

52. I tried to ask a third party to intervene to help us settle the problem.

\begin{tabular}{|c|c|c|c|}
\hline gly Agree & Agr & $\begin{array}{c}\text { Indifferent/N } \\
\text { opinion }\end{array}$ & \\
\hline
\end{tabular}


53. I wanted to be open-minded to understand the other team member's situation.

Strongly Agree

Agree

Indifferent/No

Disagree

Strongly

opinion

Disagree

54. I insisted I was right.

Strongly Agree Agree

Indifferent/No
opinion

Disagree

Strongly

Disagree

55. I pretended as if the conflict didn't exist.

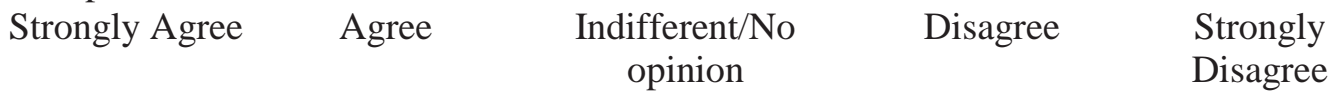

56. I was attentive to the other team member's feelings.

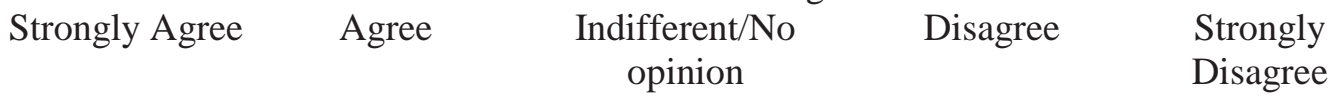

57. I let the other team member know clearly what I was thinking.

Strongly Agree Agree Indifferent/No Disagree Strongly

opinion Disagree

58. I dominated the argument until the other team member understood my position.

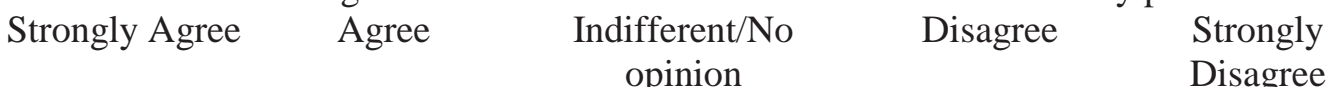

59. I insisted my position be accepted during the conflict.

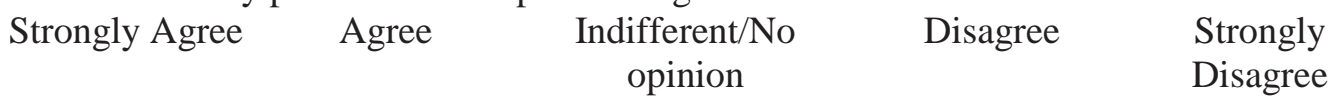

60. I suggested solutions which combined a variety of viewpoints.

\begin{tabular}{|c|c|c|}
\hline Strongly Agree & Agree & $\begin{array}{c}\text { Indifferent/No } \\
\text { opinion }\end{array}$ \\
\hline
\end{tabular}

61. I tried to downplay the importance of the disagreement.

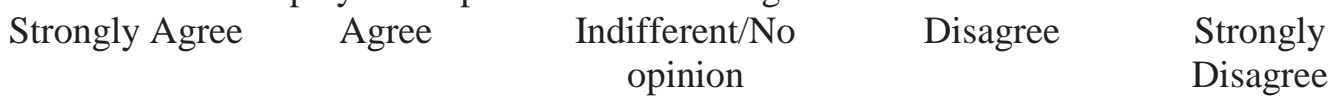

62. I stood firm in expressing my viewpoints to the other team member.

$\begin{array}{cccc}\text { Strongly Agree } \quad \text { Agree } & \begin{array}{c}\text { Indifferent/No } \\ \text { opinion }\end{array} & \text { Disagree } & \begin{array}{c}\text { Strongly } \\ \text { Disagree }\end{array}\end{array}$ 


\section{Section 6}

\section{Outcome Satisfaction}

Now you are going to respond to a series of items regarding your online discussion team satisfaction.

There are no right or wrong answers.

1. Looking back at the whole course, I am satisfied with our teamwork assignment.

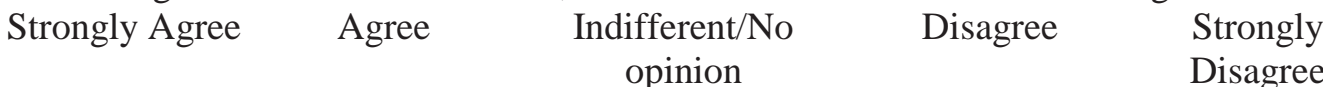

2. I think I learned many meaningful lessons throughout team assignments

$\begin{array}{cccc}\text { Strongly Agree } \quad \text { Agree } & \begin{array}{c}\text { Indifferent/No } \\ \text { opinion }\end{array} & \text { Disagree } & \begin{array}{c}\text { Strongly } \\ \text { Disagree }\end{array}\end{array}$

3. Overall, I believe that whole teamwork process of our team is valuable to driving us toward team goals.

Strongly Agree Agree Indifferent/No Disagree $\quad$ Strongly

opinion Disagree

4. Overall, I believe that our team came up with the best solution as we expected.

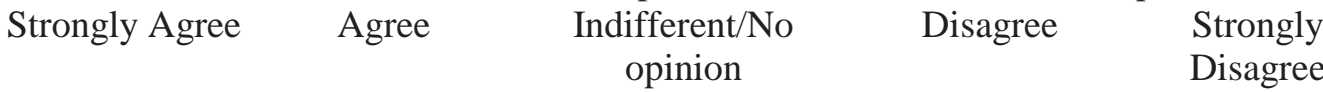

\section{Section 7}

Process Satisfaction

Now you are going to respond to a series of items regarding your online discussion team process satisfaction.

There are no right or wrong answers.

1. I enjoyed interacting with the other team members through the online discussion tool.

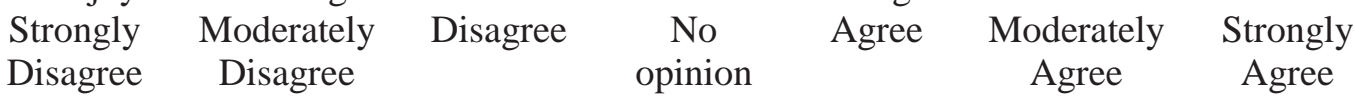

2. I felt good that I could participate with my team in coming to a conclusion about the assignment.

\begin{tabular}{|c|c|c|c|c|c|}
\hline gly & $\begin{array}{c}\text { Moderately } \\
\text { Disagree }\end{array}$ & Disagree & $\begin{array}{l}\text { No } \\
\text { oninion }\end{array}$ & Agree & $\begin{array}{l}\text { Moderately } \\
\text { A oree }\end{array}$ \\
\hline
\end{tabular}

3. I did not feel that people listened to me when I had an idea about the assignment.
Strongly Moderately
Disagree
No
Agree
Moderately
Strongly
Disagree
Disagree
opinion
Agree
Agree 
4. I felt that I could express my thoughts and feelings openly to others on the online discussion team while working on the assignment.
Strongly
Moderately
Disagree
No
Disagree
Disagree
opinion
Agree
Moderately
Strongly
Agree
Agree

5. I did not feel that the other team members understood my thoughts and feelings after I expressed them while working on the assignment.

\begin{tabular}{|c|c|c|c|c|c|}
\hline & $\begin{array}{l}\text { Moderately } \\
\text { Disagree }\end{array}$ & Disagree & $\begin{array}{c}\text { No } \\
\text { opinion }\end{array}$ & Agree & rately \\
\hline
\end{tabular}

6. I felt like my online discussion team worked very hard together to do the assignment.

\begin{tabular}{|c|c|c|c|c|c|}
\hline & $\begin{array}{l}\text { Moderately } \\
\text { Disagree }\end{array}$ & Disagree & No & Agre & $\begin{array}{c}\text { Moderately } \\
\text { Agree }\end{array}$ \\
\hline
\end{tabular}

\section{Section 8}

Face Loss

Now you are going to respond to a series of items regarding face loss during your interaction with your online discussion team members. Face represents an individual's claimed sense of positive image in the context of social interaction. Face loss is defined as the deterioration in one's social image, it constitutes a loss of social status.

There are no right or wrong answers.

1. Actions of some team member(s) made me look intimidated to other team members. Definitely

Not

Definitely

2. Actions of some team member(s) made me look weak to other team members.

Definitely

Definitely

Not

3. Actions of some team member(s) made me look unable to control what was happening to other team members.

Definitely

Definitely

Not

4. Actions of some team member(s) damaged my reputation with other team members. Definitely

Not

Definitely other team members.

Definitely

Definitely 
Not

\section{Section 9}

\section{Team Cohesion}

Now you are going to respond to a series of items regarding the team development factors during your interaction with your online discussion team members.

There are no right or wrong answers.

1. Commitment - Team members understand team goals and are committed to them. High

2. Acceptance - Team members are friendly, concerned, and interested in each other. High

3. Clarification - Team members acknowledge and confront conflict openly. High

4. Belonging - Team members listen with understanding to others. High

5. Involvement - Team members include others in the decision-making process. High

6. Support - Team members recognize and respect individual differences. High

7. Achievement - Team members contribute ideas and solutions to problems. High

8. Pride - Team members value the contributions and ideas of others.

9. Recognition - Team members recognize and reward team performance. High

10. Satisfaction - Team members encourage and appreciate comments about team efforts. High

Low 


\section{Section 10}

Demographic Information

Finally, please provide us with a little background information about yourself.

Thank you very much for your participation!!!!

1. Age:

2. Sex:

Male

Female 


\section{Appendix C: Conflicts, Face Facework Behaviors Tutorial}

Suppose you find a friend on the cafeteria and you start talking to him/her about the assignment that you need to complete for the course $\mathrm{X}$ next week, without noticing, you are involved in an interaction process between you two. From the communicational perspective, during your interaction, conflicts could show up (conflict is an awareness on the part of the parties involved of discrepancies, incompatible wishes, or irreconcilable desires).

Face is the positive, favorable social value a person claims for himself in social interactions. According to Deutsch "face is one of an individual's most sacred possessions." Face is a vulnerable resource during conflict interactions, because face can be lost, saved, or protected, and every person wants to present and protect his/her own public images. Face is negotiated during conflicts.

Facework behaviors refers to the communicative strategies that an individual uses to enact self-face and to support or challenge another's face. In a conflict, facework can be used to resolve, exacerbate, or avoid conflict, challenge another person's position, protect a person's image, and manage the shared social identity, which is part of the process of maintaining and upholding face. The typology of facework behaviors came from face-to-face interactions.

There are eleven facework behavior which are explained next with examples. The examples were extracted from an online discussion board where participants discussed the topic of "Stem Cell Research" or "Violent Video Games"

1 Aggression: Degree to which a person tries to insult, hurt, or ridicule another person. Put the other person down. Telling the other he/she is wrong, stupid, etc.

Examples:

1. So you are saying...if you kill one life now as long as you save a life later it is alright? How do you know 100\% sure that it will save that life later down in the road? It is called research for a reason which means they haven't figure it out. With what you are saying is that it is okay to kill a life now so they can do their research and possibly save someone later. But, how do you know for sure? Can you have that on your conscious?

2. Hey wake up! its 2010 people. not the 60's where you would get shunned for being prego. What im saying is why some people are against stem cell is becuase one purpose is for clonning these cells and people dont want to be clonned.

2 Problem solve: It focuses on behaviors that attempt to resolve a conflict through compromising or integrating viewpoints.

Example:

I really liked Nadal's third reason for approving violent video games because at the end of the day there will always be violence everywhere in our society. It is really unavoidable so why should video games be any different? 
3 Defend: Defend one's side without giving in; generally in the response to a perceived attack.

Example:

I understand what Roger is saying. The pregnant woman has already decided to abort her baby so why not extract the cells from the embryo? It's a good point but it's still wrong. Abortion is wrong. There are other methods of extracting stem cells, taking them from embryo's should not be allowed.

4 Respect: It refers to the sensitivity, attentiveness, and listening shown toward the other person.

Example:

Bringing awareness to a subject doesn't necessarily facilitate that subject. I'd like to see you expand on this subject, though! Perhaps you can convince me with empirical evidence - assuming it exists.

5 Pretend: Pretending the there is no conflict or that you are not upset or hurt by what has happened.

Example:

There is no example for this facework behavior.

6 Apologize: Admit that you made a mistake telling the other. Apologize for the behavior during the conflict.

Example:

I meant to put that reason under rejecting. Again sorry, I have been dealing with a family situation.

7 Third party: Involving an outside person to help to resolve the conflict. Example:

Hey Pete, it looks like you do not understand my point. Could you ask Johanna to see if she can clarify it?

8 Express Emotions: Express how one is feeling without defending or attacking the other

Example:

I'm not sure if this is humanly moral BUT it can be used in turn to SAVE A LIFE DOWN THE ROAD!! End a life, help someone's in the future??

9 Remain calm: Attempting to stay calm and unemotional. It refers to trying to maintain composure during conflict and not getting angry.

Example:

Like I mentioned on my other post, I think you are misinterpreting my point.

10 Private discussion: Avoid talking about the problem in public.

Example:

Could we talk tonight? Call me at 888-888-8888, honestly, I do not want everybody else read my comments to your last post.

11 Give in: Accommodate the other person and let them win during the conflict.

Example:

I am fine with whatever topic we choose to discuss as a group. However, I would also like to point out that I am much more comfortable with the topic on violent video 
games. 